\title{
Kantauralin ajoitus ja paikannus: perustelut puntarissa'
}

Tämän tarkastelun tarkoituksena on ajoittaa ja paikantaa kantauralin puhuma-alue perinteisen historiallis-vertailevan kielentutkimuksen metodein. Mukaan on otettu kaikki mahdolliset kielelliset seikat, joilla olen ajatellut voivan olla merkitystä asian kannalta, poislukien ne, joita Petri Kallio on äskettäin käsitellyt aihepiiriltään vastaavassa tarkastelussa (Kallio 2006), jonka jatkoksi katson nyt käsillä olevan artikkelin.

Ensimmäisessä luvussa referoin aikaisemmin toisessa yhteydessä esittämiäni tuloksia, jotka liittyvät varhaisimpaan kantauralin jälkeiseen murrerajaan. Varhaisimman uralilaisen murrerajan sijainnilla on vaikutusta kantauralilaisen puhuma-alueen paikannukseen; samoin se vaikuttaa muuttuneen levikkikriteerin kautta kantauralilaisen sanaston lukumäärään, jolla taas on vaikutusta kantauralin ajoitukseen; lisäksi se vaikuttaa yksittäisten sanojen kantauralilaisuuteen, millä on vaihtelevassa määrin vaikutusta kantauralin ajoitukseen ja paikannukseen.

Toisessa luvussa käsittelen erittäin lyhyesti sovellettua metodia, eli lähinnä äänneja levikkikriteerin välistä suhdetta: millä perusteella sanaa voidaan pitää kantakielestä perittynä, millä perusteella myöhempänä lainana?

Kolmannessa luvussa käsittelen kantauralin ajoituksen kannalta olennaisia seikkoja ja neljännessä luvussa kantauralin paikannuksen kannalta olennaista todistusaineistoa. Esitän, että kantauralin ekspansio on alkanut myöhemmin ja idempää kuin suomalaisessa keskustelussa on viime vuosikymmeninä uskottu.

Viidennessä luvussa vastaan lyhyesti muutamaan olennaiseen kysymykseen uuden hypoteesin mukaisesta uralilaisesta ekspansiosta, sen syistä ja ilmenemisestä arkeologisessa aineistossa.

Käytän kirjoituksessani vain muutamia lyhenteitä: $U=$ uralilainen (kantakieli), vk-U = varhaiskantaurali, mk-U = myöhäiskantaurali, $\mathrm{SU}=$ suomalais-ugrilainen (kantakieli), LU = länsiurali (itämerensuomen, saamen ja mordvan yhteinen kantakieli), IU = itäurali (unkarin, mansin, hantin ja samojedin yhteinen kantakieli), IE = kantaindoeurooppa, $\mathrm{A}=$ kanta-arja (myöhäisvaihe), saame $\mathrm{P}=$ pohjoissaame, mordvaE $=$ ersämordva. Eräiden nykykielten murteista käytetään seuraavia lyhenteitä: metsänenetsi Lj. $=$ Ljaminjoki, $\mathrm{Nj} .=$ Njalinan kylä, $\mathrm{P}=$ Purjoki $\mid$ mansi $\mathrm{N}=$ pohjoismurre, LM $=$ Keski-Lozva, LU = Ala-Lozva, $\mathrm{P}=$ Pelymka, $\mathrm{K}=$ Konda, $\mathrm{T}=$ Tavda $\mid$ hanti $\mathrm{DN}=$ Demjanka, $\mathrm{V}=\mathrm{Vah}, \mathrm{Vj} .=$ Vasjugan, Trj. $=$ Tremjugan $\mid$ mari $\mathrm{O}=$ itämurre, $\mathrm{M}=$ keskimurre, $\mathrm{W}=$ länsimurre, $\mathrm{NW}=$ luoteismurre, $\mathrm{Mwo}=$ keskimurteiden Volgan murre, Mup $=$ keskimurteiden Upšan murre $\mid$ komi $V=$ Vyčegda, $\mathrm{S}=$ Sysola, $\mathrm{I}=\mathrm{Ižma}$, $\mathrm{L}=$ Luza, $\mathrm{P}=$ permjakki.

1 Esitän kiitokseni kaikille, jotka ovat kommentoineet tätä artikkelia sen eri työvaiheissa tai joilta olen saanut apua ja vastauksia yksityiskohtiin liittyvissä kysymyksissä: Ante Aikio, Kaisa Häkkinen, Juha Janhunen, Petri Kallio, Janne Saarikivi, Heikki Simola ja Jussi Ylikoski. 


\section{Metodi}

Tässä tarkastelussa vertailen eräitä kantauralin ajoituksen ja paikannuksen kannalta tärkeitä sanoja. Koska kriteerinä on sanojen esiintyminen jo kantauralissa, on tarpeen määritellä käytetyt äänne- ja levikkikriteerit. Soveltamani levikkikriteerin perusteella kantauraliin palautettavan sanan täytyy esiintyä ainakin yhdessä läntisimmistä (itämerensuomi, saame ja mordva) ja yhdessä itäisimmistä kielihaaroista (mansi, hanti, samojedi ja pienin varauksin unkari). Tiukempiakin levikkikriteerejä on esitetty (esim. K. Häkkinen 1983), mutta nähdäkseni uralilainen äännehistoria on viime vuosikymmeninä siinä määrin tarkentunut, että aukkoinenkin levikki riittää, kunhan äännevastaavuus on säännöllinen.

Äännetasoa pidän sanojen levikkiä tärkeämpänä kantauralilaisuuden kriteerinä siksi, että esimerkiksi sibilanttivastaavuudet läntisten ja itäisten kielten välillä ovat sellaiset, ettei myöhempi lainautuminen voi mitenkään tuottaa perintösanaston kaltaista edustusta. Esimerkiksi eräässä myöhemmin käsiteltävässä yhdyssanassa on kaksi säännöllisesti edustuvaa sibilanttia: permin $s$ :ää vastaa mansin $s$ ja permin $s$ :ää mansin $t$. Kumpikaan edustus ei voi selittyä lainaksi toisesta, koska kummassakin kielessä oli paremmin substituuteiksi sopivia äänteitä; koska itäuralilaiset sibilantiston muutokset ovat tapahtuneet heti kantauralin jälkeen, on vastaavuus palautettava aikaan ennen itäuralilaisia muutoksia - käytännössä siis kantauraliin. Tilannetta ei muuta sanan suppea levikki; sibilanttien osalta siis äännekriteeri riittää, vaikka levikkikriteeri ei täyttyisikään.

Sen sijaan laajalevikkinenkin sana voidaan tuomita nuoreksi lainaksi tai kulkusanaksi, jos äännevastaavuus paljastaa tällaisen tilanteen. Äännetaso on siis tässäkin ratkaisevampi seikka kuin yksin levikki. Joidenkin äänteiden kohdalla peritty edustus ei kuitenkaan erotu myöhempien lainojen edustuksesta, eikä levikki tällaisissa tapauksissa voi aukottomasti todistaa sanan palautumista jo kantauraliin.

Milloin sitten voidaan sanaa pitää myöhemmin tytärkielestä toiseen lainautuneena? Pääsääntöisesti vain silloin, kun verratut vastineet muistuttavat toisiaan nykytasolla enemmän kuin varhaisemmilla rekonstruoiduilla kielentasoilla tai kun jokin äänteellinen piirre viittaa selvästi jonkin toisen kielihaaran erilliskehitykseen. Näiden vaihtoehtojen ulkopuolelle jäävät vielä sellaiset tapaukset, joissa äännevastaavuudet ovat epäsäännöllisiä mutta joissa verratut vastineet muistuttavat nykytasolla toisiaan vähemmän kuin varhaisemmilla rekonstruoiduilla kielentasoilla. Tällöin voidaan lainautumisvaihtoehto sulkea pois ja olettaa sanassa tapahtuneen jollain taholla epäsäännöllistä äännekehitystä. Vastineet voidaan siis myös tässä tapauksessa palauttaa kantakieleen, vaikka ne eivät aivan säännöllisiä olisikaan, koska vastaavuus ei selity myöhemmän lainautumisen kautta.

Tilannetta mutkistaa ns. etymologinen nativisaatio. Kaksikieliset puhujat oppivat tiedostamaan etymologisesti yhteenkuuluvat sanat ja sopeuttamaan uudet lainasanat vanhaan vastaavuusmalliin. Kielten ei välttämättä tarvitse olla sukukieliä, vaan vertailun mahdollistaa myös vanhempi lainasanakerrostuma. Etymologinen nativisaatio saattaa paljastua murrelevikin perusteella tai siksi, että sana ei esimerkiksi merkityk- 
sensä vuoksi voi olla vanha. Myös muut äänteet saattavat paljastaa sanan nuoreksi lainaksi. (Aikio 2007.)

Myös pitkään naapureina puhuttujen muinaisten uralilaisten kielimuotojen välillä voisi teoriassa olettaa tapahtuneen etymologista nativisaatiota - erityisen tärkeä tämä kysymys on varhaisimman oletetun murrerajan molemmin puolin, permin ja mansin välillä. Merkittävää on kuitenkin, että konsonantiston kohdalla tällainen näyttäisi yleensä olevan harvinaista, poislukien tunnistettavat johdin- tms. ainekset (Aikio 2007). Tämä liittynee siihen, että sanat hahmotetaan pitkälti vokaalien kautta; ainakin Aikion esimerkeissä etymologinen nativisaatio koskee vain vokaaleja, kun taas juuri konsonanttiedustus paljastaa, että sana on nuori ja että siinä on tapahtunut vokaalien kohdalla etymologinen nativisaatio. Mikäli siis löytyy sanoja, joiden vastineet ovat konsonantiston osalta säännöllisiä ja vokaaliston osalta epäsäännöllisiä, voitaneen vastineet pääsääntöisesti palauttaa kantakieleen, kun taas päinvastaisessa tapauksessa etymologisen nativisaation mahdollisuutta ei voida sulkea pois (olettaen, että kieliä on puhuttu pitkään naapureina ja on vallinnut laaja kaksikielisyys).

Käytän esityksessä konkreettisia vuosilukuja (eaa. eli ennen ajanlaskun alkua) ja kilometrejä mahdollistaakseni lukijalle kantauralilaisen puhuma-alueen sijoittamisen esihistorian kartalle. Luvut ovat luonnollisesti karkeita arvioita ja sisältävät epävarmuudesta johtuvan virhemarginaalin, joka ajoitusten osalta on satojen vuosien ja paikannusten osalta satojen kilometrien suuruusluokkaa. En kuitenkaan pidä tarpeellisena virhemarginaalin toistamista jokaisen luvun kohdalla erikseen, joten tuon epätarkkuuden ilmi tässä vaiheessa koko tarkastelun osalta.

\section{Taustaa}

Vaikka jäljempänä todistusaineistona esittelemäni sanat ovatkin enimmälti alan aikaisemmista tutkimuksista poimittuja, uutta on monen sanan kohdalla niiden tulkitseminen jo kantauralilaisiksi. Perinteisesti kantauralilaisuuden kriteerinä on pidetty sanan löytymistä suomalais-ugrilaisesta ja samojedihaarasta, mutta äskettäin olen esittänyt (J. Häkkinen 2007), ettei varhaisin uralilainen murreraja olisikaan erottanut samojedihaaraa muusta kielikunnasta vaan pikemminkin ugrilais-samojedilaiset kielet suomalais-permiläisistä. Näin sanan kantauralilaisuuteen riittää sanan esiintyminen kummallakin mainitulla taholla: nyt aiemmin suomalais-ugrilaisiksi luokiteltuja sanoja voidaan myös pitää jo kantauraliin palautuvina. Tässä käsittelen perusteluja vain erittäin lyhyesti; tarkemmin niihin voi syventyä mainitussa työssäni.

Samojedin varhaista eroa muusta kielikunnasta on perusteltu lähinnä yhteisen sanaston vähyydellä. Yhteisen sanaston vähyys ei kuitenkaan voi todistaa varhaisesta erosta, koska se voi selittyä toisinkin: samojedi on voinut myöhemmin vaihtaa sanastoaan suuressa mitassa (Salminen 2001; J. Häkkinen 2007). Esimerkiksi kantamongolin hajoaminen alkoi vasta noin 800 vuotta sitten, mutta monguorissa ns. mongolilaisesta sanastosta on säilynyt vain $39 \%$, kun taas halhassa on säilynyt $98 \%$ (Rybatzki 2003: 384-386). Vanhasta yhteisuralilaisesta (uuden kriteerin mukaan) sanastosta samojedissa on säilynyt 123 (Sammallahti 1988: U-kerrostuma) kaikkiaan 
390:stä sanasta (Sammallahti 1988: U + SU-kerrostumat) eli 32 \%, kun taas itämerensuomessa vanhoista sanoista on säilynyt $69 \%$. Osuudet ovat siis vertailukelpoisia mongolikielten kanssa, joten tältä osin ei ole tarvetta eikä perustetta olettaa samojedin eronneen yhteisestä kantakielestä itämerensuomea aikaisemmin.

Se taas, että uralilaisella taholla suurin säilymäprosentti on huomattavasti pienempi kuin mongolilaisella puolella, johtuu suoraan siitä, että kantaurali on hajonnut niin paljon aikaisemmin: perintösanoilla on ollut pidempi aika kadota kielistä. Lisäksi on huomioitava, että aikaväli kantamongolista monguoriin vastaa esimerkissä aikaväliä kantauralista kantasamojediin eikä nykyisiin samojedikieliin. Niinpä voidaan sanoa, että vain jos kantasamojedi on alkanut hajota hieman alle tuhat vuotta sen jälkeen kun samojedihaara erosi kantauralista, on sanaston uusiutumisnopeus esisamojedissa (jaksolla kantauralista kantasamojediin) ollut yhtä suuri kuin monguorissa. Koska kantasamojedi näyttää alkaneen hajota vähän ennen ajanlaskun alkua, olisivat sanaston muutosnopeudet monguorissa ja samojedissa yhtäläiset vain, jos kantaurali olisi alkanut hajota vasta hieman ennen vuotta 1000 eaa. Tämä ajoitus on selvästi liian myöhäinen, joten samojedin sanaston uusiutumisnopeutta ei tarvitse pitää läheskään niin suurena kuin monguorissa. On siis hyvinkin mahdollista, että samojedin yhteisuralilaisen sanaston vähyys johtuu sanaston uusiutumisesta; tämä seikka ei siksi voikaan yksinään todistaa samojedin varhaisesta erosta.

Kuitenkin samojedin kieliopillisen konservatiivisuuden on nähty olevan ristiriidassa sen oletuksen kanssa, että samojedi olisi vaihtanut sanastoaan suuressa mitassa. Juha Janhunen on esittänyt, että tällaiset kielet olisivat harvinaisia, mutta samalla hän kuitenkin nimeää japanin sellaiseksi kieleksi, jossa kieliopillinen konservatiivisuus yhdistyy sanaston voimakkaaseen uusiutumiseen (Janhunen 2008). Epäilemättä muitakin tällaisia kieliä voitaisiin löytää - ne vain ovat tähän saakka jääneet huomaamatta, koska yhteisen sanaston vähyys on automaattisesti tulkittu varhaisen eriytymisen merkiksi. Tällöinhän sanaston vaihtumisnopeus ei näyttäydy suurena eikä ristiriitaa kieliopillisen konservatiivisuuden kanssa synny.

Yhteisen sanaston määrä ei siis riitä todistamaan samojedin varhaista eroa muusta kielikunnasta. Kuitenkin myös äännetason piirteitä on esitetty tämän oletuksen tueksi: Pekka Sammallahti rekonstruoi kourallisen suomalais-ugrilaisia äänteellisiä uudennoksia, jotka olisivat tapahtuneet samojedin jo erottua kantauralista (Sammallahti 1988: 486):

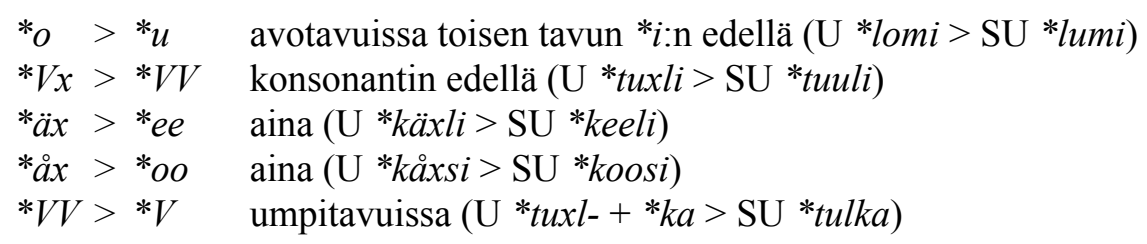

Kuitenkaan nämä muutokset eivät näyttäisi olevan todistusvoimaisia. Ensimmäinen muutos on tulkinnanvarainen, koska se on yhtä hyvin voinut tapahtua toiseen suuntaan vasta samojedissa: aineiston perusteella samojedin ${ }^{*} o$ vastaa suomalais-ugrilaista 
*u:ta vain $i$-vartaloisissa alkuperäisissä avotavuissa, kun taas $i$-vartaloisissa alkuperäisissä umpitavuissa samojedissakin on *u (J. Häkkinen 2007: 50). Voidaan siis ajatella, että kantasamojediin tultaessa vokaalijärjestelmästä kadonnut foneemi $*_{O}$ (joka sulautui säännöllisesti alkuperäiseen *a:han) ilmestyi järjestelmään uudelleen, kehittyen määräehdoin alkuperäisestä *u:sta.

Toista muutosta voidaan pitää jo yhteisuralilaisena muutoksena $* V x>* V \hat{\partial}$, koska myös läntiset pitkät vokaalit ovat ainakin foneettisesti käyneet läpi tämänkaltaisen välivaiheen. Kolmas muutos näyttäisi tapahtuneen vain itämerensuomessa ja saamessa, koska mordvasta itään * äx ja *ex näyttävät pysyneen erillään. Neljättä muutosta ei näyttäisi edes tapahtuneen, koska koko kielikunnan mitassa lähtöasuksi voidaan sujuvimmin rekonstruoida $*^{o x}$, koska sen edustus moniaalla vastaa lyhyen $*_{o}$ :n edustusta. Viides muutos taas näyttäisi olevan yleisuralilainen fonotaktinen rajoitus, joka epäilemättä olisi toiminut myös samojedissa, jos tämänkaltaiset johdokset siellä olisivat säilyneet - johdoksen puuttuessahan emme voi saada varmaa tietoa sen edustuksesta.

Sen sijaan voidaan esittää joukko ugrilais-samojedilaisia (itäuralilaisia) äänteellisiä uudennoksia (J. Häkkinen 2007: 71-78):

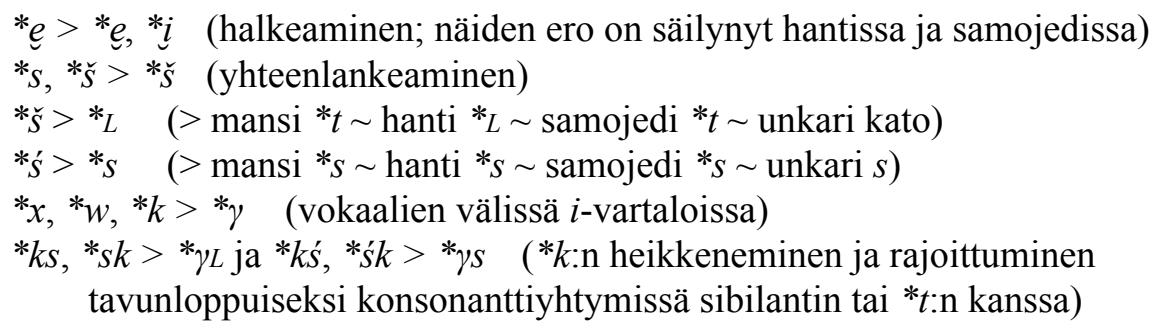

Erityisesti on korostettava, että vanhat indoeurooppalaiset lainasanat osoittavat itäuralin sibilanttiedustuksen olevan sekundaari, kun taas lännempänä alkuperäiset sibilantit ovat säilyneet (ks. esimerkkejä U *'seta '100' ja U *asira 'ruhtinas' arjalaisten lainasanojen kohdalta myöhemmin tässä tarkastelussa). Samojedissa sibilanttien edustus on jopa identtinen mansin kanssa, joten ei ole ongelmaa johtaa näitä kieliä yhteisestä kantamurteesta, vaikka jostain syystä ugrilaisten kielten edustusta käsiteltäessä samojedin edustus on usein jätetty täysin huomioimatta (esim. Honti 1998: 179). Perinteisesti on tämän "ugrilaisen" kehityksen välivaiheeksi oletettu soinnitonta dentaalispiranttia $* \vartheta$, mutta jukagiirin uralilaisten lainasanojen $l$-edustuksen vuoksi (kun kantauralissa on $*_{s}$ tai $*_{s}$; ks. Nikolaeva 2006: 67) uskottavin välivaihe on soinniton frikolateraali $*_{L}$, jollainen kantahantiinkin rekonstruoidaan. Ajallisin ja alueellisin perustein kantahanti ei kuitenkaan ole voinut olla kontaktissa esijukagiirin kanssa, vaan $*_{L}$ on rekonstruoitava jo itäuraliin (ja esisamojediin).

Kahta viimeistä konsonantistonmuutosta voidaan perustella sekä taloudellisuudella että yhtenevällä edustuksella. Ante Aikio on äskettäin osoittanut, että *x:n lisäksi myös $* w$ ja $* k$ näyttävät samojedissa kadonneen vokaalien välissä $i$-vartaloissa (Aikio 2002: 49). Tämä muistuttaa mansin ja hantin kehitystä: niissähän nämä kolme äännettä ovat vokaalien välissä langenneet yhteen $*_{\gamma}$ :ksi ainakin $i$-vartaloissa ( $a$-vartaloista on 
niukemmin aineistoa). Olisi taloudellisempaa olettaa samojedissa vain yhden konsonantin kadonneen kolmen sijasta.

Lisäksi samojedin yhdistää mansin ja hantin edustukseen se, että $* k$ :n edustus yhtymässä $* t$ :n ja sibilanttien $\left({ }^{*} s,{ }^{*}{ }_{s}\right.$, $\left.{ }^{\prime}\right)$ kanssa vastaa edellä mainittua $* k$ :n edustusta vokaalien välissä $i$-vartaloissa: samojedissa tuloksena on $* k$ :n kato, mansissa ja hantissa pääsääntöisesti $* k$ :n heikkeneminen ${ }^{*} \gamma$ :ksi ja metateesi tavunloppuiseen asemaan. Kun sitten ${ }^{*} w$ konsonanttiyhtymissä näyttää samojedissa kadonneen vain tavunloppuisessa asemassa (Aikio 2002: 49) ja vokaalienvälisessä asemassa kehittyneen kuten $* k$, ei liene liian kaukaa haettua täydentää palapeli olettamalla myös $* k$ :n kadonneen konsonanttiyhtymissä vain tavunloppuisessa asemassa. Tämä edellyttäisi vain mainituissa konsonanttiyhtymissä $* k$ :n metateesiä tavunloppuiseen asemaan - aivan kuten mansissa ja hantissakin tapahtui.

Toisin sanoen samojedin edustus voidaan taloudellisimmin johtaa samojen kehitysvaiheiden kautta kuin mansin ja hantin edustus: vokaalien välissä $*_{x},{ }^{*} w$ ja $* k$ olisivat langenneet yhteen $* \gamma$ :ksi ainakin $i$-vartaloissa, ja konsonanttiyhtymissä dentaaliobstruenttien kanssa $* k$ olisi heikentynyt $* \gamma$ :ksi ja siirtynyt tavunloppuiseen asemaan. Tämän jälkeen tarvitsee olettaa samojedissa tapahtuneen vain * $\gamma$ :n kato. Itäuralilainen kehitys voidaan rekonstruoida seuraavasti:

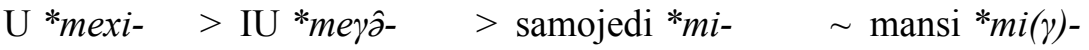

$$
\begin{aligned}
& \sim \text { hanti *me(j) 'antaa, myydä' }
\end{aligned}
$$

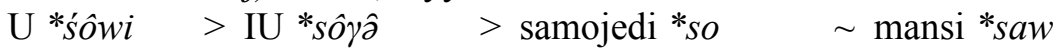

$$
\begin{aligned}
& \sim \text { hanti *sooyaa } \sim \text { unkari szó : szava- 'suu' }
\end{aligned}
$$

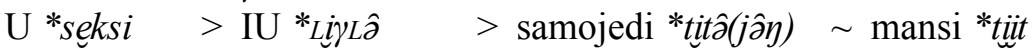

$$
\begin{aligned}
& \sim \text { hanti *LüjyeL'sembramänty' }
\end{aligned}
$$

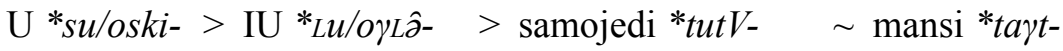

$$
\begin{aligned}
& \sim \text { hanti * LooyeL 'jauhaa suussa' }
\end{aligned}
$$

Voidaanko sitten yhteiset äänteenmuutokset selittää muulla tavoin kuin olettamalla yksi suppea-alainen itäuralilainen murrekeskus, jossa muutokset ovat tapahtuneet? Äänteenmuutos ei tapahdu hetkessä vaan on pitkällinen prosessi, jonka aikana uusi äänne hiljalleen syrjäyttää vanhan. Alue, jolle uusi äänne ei enää leviä, erottuu omana murrealueenaan. Vaikka äänteenmuutosprosessin lopputuloksena oleva äänne lainattaisiinkin jo aiemmin eriytyneeseen kieleen, sitä ei enää osattaisi välttämättä yhdistää prosessin lähtökohtana olleeseen äänteeseen. Esimerkiksi metsänenetsiin on lainattu hantista $L$-äänne (soinniton frikolateraali), mutta hantissa sen äännelaillisena lähtömuotona on itäuralin $*_{L}\left(<\right.$ kantauralin $*_{S}$ ja $\left.*_{S}\right)$, kun taas metsänenetsissä se on alkanut syrjäyttää foneettisesti läheisiä $l$ - ja $r$-äänteitä: $\mathrm{U} *$ ela- 'elää' > samojedi *ilä- > metsänenetsi Lj. jićĹi- $\sim \mathrm{Nj}$. jiŕŕi- | U *kura 'veitsi' > samojedi *kârå > metsänenetsi Lj., Nj. kar $\sim$ P kaL (metsänenetsin esimerkit Lehtisalo 1956: 127, 151). Näin voidaan heti nähdä, ettei kyseessä ole vanha hantille ja metsänenetsille geneettisesti yhteinen äänteenmuutos. Metsänenetsit ovat lainanneet vain äänteenmuutosprosessin päätepisteen, jolla he ovat alkaneet korvata oman kielensä foneettisesti läheisiä äänteitä eivätkä suinkaan kantauralilaisen ${ }^{*} s: n$ jatkajaa samojedin *t:tä. 
Aina ei ole kuitenkaan yhtä helppo erottaa sekundaariseen kontaktivaikutukseen perustuvaa äännelainaa. Jos esimerkiksi äänne lainataan ja sillä substituoidaan sama äänne, joka lainanantajakielessä tai -murteessa on äänteenmuutoksen lähtömuoto, näyttää äänteenmuutos yhteiseltä ja vanhalta. Kuitenkin silloin kun suurella joukolla äänteenmuutoksia on sama levikki, on kyseessä suurella todennäköisyydellä vanha murreraja. On hyvin epätodennäköistä, että naapureilta olisi lainattu monia äänteitä, että ne olisivat levinneet keskenään tarkalleen yhtä laajalle alueelle ja että niillä kaikilla olisi vielä onnistuttu korvaamaan juuri se äänne, jonka vastineesta kyseinen naapureilta lainattu äänne olisi kehittynyt. Samojedi onkin perustelluinta palauttaa itäuralilaiseen kantamurteeseen yhdessä mansin, hantin ja unkarin kanssa.

Lisäksi on otettava huomioon se, mikä lopulta erottaa kaksi lähisukuista murretta omiksi kielikseen. Määritelmällisestihän erillisistä kielistä puhutaan silloin, kun kahden kielimuodon puhujat eivät enää pysty ymmärtämään toisiaan. Käytännössä kieleytyminen liittyy siis etupäässä sanaston tasoon. Kielten sanastot voi sysätä keskinäisen ymmärrettävyyden rajan yli joko yhteisten sanojen merkitysten muuttuminen jommallakummalla tai kummallakin taholla (yleistä esimerkiksi suomen ja viron sanojen välillä) tai yhteisten sanojen korvautuminen lainasanoilla jommallakummalla tai kummallakin taholla; jälkimmäisessä tapauksessa kyseessä ovat tietysti eri lainanantajakielet (yleistä esimerkiksi suomen ja karjalan välillä: paljon lainasanoja vastaavasti ruotsista ja venäjästä).

Koska äänteelliset erot eivät häiritse keskinäistä ymmärtämistä, ei yksittäisiin äänteenmuutoksiin myöskään kohdistu muutospainetta. Niinpä juuri äännetasolla säilyy jälkiä kielimuodon alkuperäisestä taksonomisesta statuksesta: esimerkiksi nykyään suomen kielen päämurreryhmiksi luettavat länsi- ja itämurteet ovat historiansa aikana ehtineet kehittyä selvästi eri suuntiin, ennen kuin yhteinen valtio ja kirjakieli muuttivat kehityksen suunnan. Vastaavasti nykyisen viron kielen pohjois- ja etelämurteet edustavat alkuaan hyvin erilaisia kielimuotoja; näyttää jopa siltä, että eteläviro on eronnut kantasuomalaisesta kieliyhteydestä ensimmäisenä ja että kaikki muut itämerensuomalaiset kielet (myös pohjoisviro ja suomen päämurteiden edeltäjät) muodostivat vielä jonkin aikaa tämän eron jälkeen yhtenäisen kielimuodon, kantasuomen rannikkomurteen (Kallio 2007). Silloinkin kun kielimuodot sanastonsa osalta lähentyvät toisiaan sekundaaristi, kuten vaikkapa juuri suomen kielen länsi- ja itämurteet, jäävät äänne-erot yleensä ennalleen: synkronisessa yhtenäisyydessä on jatkuvasti näkyvissä aikaisempi diakroninen erillisyys.

Esitetyillä perusteilla pidänäännetasoa luotettavampana varhaisimman murrerajan ilmaisijana kuin sanatasoa. Äänteellisesti samojedi näyttäisi palautuvan itäuralilaiseen (ugrilais-samojedilaiseen) kantamurteeseen, ja sen säilyttämän yhteisuralilaisen sanaston vähäisyys voidaan selittää sanaston suurella uusiutumisnopeudella. Tällainen oletus sopii hyvin yhteen sen kielenulkoisen seikan kanssa, että samojedihaara on pitkään ollut erossa kielisukulaisistaan: samojedikielistä selkuppi kohtasi hantin Obin keskijuoksulla vasta joskus ensimmäisellä ajanlaskun alun jälkeisellä vuosituhannella, ja nenetsi kohtasi hantin Obin alajuoksulla vieläkin myöhemmin.

Kantauralin voidaan olettaa jo hyvin varhain jakautuneen kolmia läntiseen ( $>$ itämerensuomi, saame ja mordva), keskiseen ( $>$ permi ja mari, tai kumpikin heti alusta 
erillään) ja itäiseen murteeseen ( $>$ unkari, mansi, hanti ja samojedi). Vaikka eniten äänteellisiä uudennoksia näyttääkin löytyvän itäuralilaisen murteen tueksi, on tilanne toistaiseksi auki sen osalta, ovatko läntiset ja keskiset kielet muodostaneet vielä hetken aikaa yhteisen kantamurteen itäuralilaisen murteen jo eriydyttyä. Todellisuudessa näin on varmasti ollut, koska kaksi uutta murretta tuskin irtoaa täsmälleen samalla hetkellä, mutta sen toteennäyttämiseksi voi olla vaikea löytää yksiselitteisiä kielellisiä todisteita.

\section{Kantauralin ajoitus}

\section{I. Omaperäisen sanaston määrä}

Juha Janhunen on toistuvasti korostanut, että kantauraliin rekonstruoitujen sanavartaloiden vähäinen lukumäärä todistaisi kantakielen vanhuudesta esimerkiksi kantaindoeurooppaan verrattuna. Hän kuitenkin tiedostaa myös, että lukumääräero esimerkiksi kantaindoeurooppalaisten sanojen lukumäärään verrattuna johtuu osittain siitä, että uralilaisella puolella on perinteisesti käytetty binaarisesti jakautuvaa sukupuuta, kun taas indoeurooppalaisella puolella on useita taksonomisesti tasa-arvoisia haaroja. (Janhunen 2008.)

Tämä on tietysti yksi tekijä, mutta koko ero ei kuitenkaan selity tästä. Merkittävää on pikemminkin, että uralilaisella puolella binaarisen luokittelun rajan on nähty erottavan yksi kielihaara kaikista muista. Jos nimittäin binaarinen raja erottaisikin vaikkapa ugrilais-samojedilaiset kielet suomalais-permiläisistä, kasvaisi kantauralilainen sanakorpus huomattavasti: ensiksikin siksi, että yleensä useammassa kielihaarassa on todennäköisemmin säilynyt yhteensä enemmän sanoja kuin yhdessä, ja toiseksi siksi, että juuri samojedissa perintösanastoa näyttää säilyneen poikkeuksellisen vähän (ks. toinen luku).

Pekka Sammallahden sanalistassa uralilaisia sanoja on 123 (vastine samojedissa) ja suomalais-ugrilaisia sanoja 267 (ei vastinetta samojedissa) (Sammallahti 1988). Ante Aikio on kuitenkin hiljattain löytänyt uusia samojedietymologioita sekä päivittänyt aiemmin hylättyjen rinnastusten perusteluja ja näin nostanut perinteisen taksonomian mukaan määriteltyä kantauralilaista sanakorpusta useilla kymmenillä; lisäksi hän on listannut uskottaviksi katsomiaan muiden tutkijoiden esittämiä samojedietymologioita (Aikio 2002, 2006a). Kokonaan uusia samojedietymologioita viime vuosilta on yhteensä 60, mikä nostaa perinteisen taksonomisen kriteerin mukaisen kantauralilaisen sanaston lukumäärän jo lähelle kahtasataa sanaa.

Käsillä olevassa tarkastelussa noudatetaan kuitenkin toisenlaista levikkikriteeriä, jolloin kantauraliin palautettavan sanan on esiinnyttävä säännöllisessä asussa vähintään yhdessä läntisistä (itämerensuomi, saame, mordva) ja yhdessä itäisistä kielistä (unkari, mansi, hanti, samojedi). Samalla kriteeri saadaan yhteismitalliseksi indoeurooppalaisella puolella yleisesti sovelletun kriteerin kanssa: siinähän kantaindoeurooppaan palautettavalla sanalla täytyy olla vastine ainakin yhdessä eurooppalaisessa ja yhdessä aasialaisessa kielihaarassa. 
Uudesta levikkikriteeristä johtuen esitetyt uudet samojedietymologiat nostavat kantauralilaista sanakorpusta (johon nyt siis lasketaan mukaan myös suurin osa aiemmin suomalais-ugrilaisiksi katsotuista sanoista) vain silloin, kun uudella samojedietymologialla on vastine läntisissä kielissä muttei ugrilaisissa kielissä. Uusista samojedietymologioista yli 30 täyttää uudistetut kantauralilaisen sanan kriteerit. Mikäli kantauralin varhaisin murreraja voidaan tulevaisuudessa nykyistä varmemmin sijoittaa keskisten (mari, permi) ja itäisten kielihaarojen (unkari, mansi, hanti, samojedi) väliin, voidaan kantauralilaisiksi alkaa laskea myös ne uudet samojedietymologiat (ja tietysti aiemminkin tunnetut sanat), joilta puuttuu vastine vain läntisistä kielistä.

Niinpä kriittisen tutkimuksen saavuttama kantauralilaisen sanaston mahdollinen maksimimäärä on soveltamallani taksonomisella kriteerillä tällä hetkellä karkeasti arvioiden hieman alle viisisataa sanaa. Eikä viidensadan kantauralilaisen sanan rajapyykin tavoittaminenkaan ole lähitulevaisuudessa mahdotonta, koska kantauraliin esittämieni uusien vokaalien ansiosta (J. Häkkinen 2007) voidaan todennäköisesti havaita säännöllisiksi useita sellaisia sanoja, joita kriittinen tutkimus on toistaiseksi pitänyt liian epäsäännöllisinä. Käytännössä vähemmän kriittisten tutkijoiden hyväksymistä sanoista saattaa tulla myös kriittisten tutkijoiden hyväksymiä sanoja, vaikka tietysti on myös edelleen mahdollista löytää uralilaisista kielistä aivan uusia, aiemmin esittämättömiä laajalevikkisiä sanoja (Saarikivi 2007).

Ajoitettaessa kantakieltä sanojen lukumäärän perusteella on myös edellä mainittu kriteerien vaihteleva tiukkuus otettava huomioon. Osa tutkijoista nimittäin ajattelee, että sellaisiakin sanoja, joissa on äänteellisiä epäsäännöllisyyksiä, voidaan pitää kantauralilaisina, mikäli niillä on laaja levinneisyys ja ne kuitenkin muistuttavat suuresti (vaikkakin epäsäännöllisesti) toisiaan. Kaisa Häkkinen (2001) on laskenut UEW:n uralilaisiksi (284) ja suomalais-ugrilaisiksi (459) esittämät sanat, joita on yhteensä 743. Luku on suuruusluokaltaan lähes kaksinkertainen verrattuna kriittisemmän tutkimuksen hyväksymien sanojen lukumäärään. Myös indoeurooppalaisella puolella on käytössä erilaisia kriteerejä: IEW sisältää noin 2000 sanavartaloa, mutta kriittinen nykytutkimus hyväksyy tästä määrästä arviolta vain puolet (Kallio 2006: 3).

Kun siis sekä levikkikriteeri että kriittisyysaste kalibroidaan yhteensopiviksi, ovat kantauralilainen ja kantaindoeurooppalainen sanakorpus jo huomattavasti lähempänä samaa suuruusluokkaa (n. 440 vs. 1000 ). Jäljelle jääneen eron selittävät neljä seikkaa: kielikuntiin kuuluvien kielten huomattava lukumääräero, indoeurooppalaisten kielten varhainen muistiin merkitseminen, indoeurooppalaisten kielten tutkijoiden suurempi määrä (näistä ks. Kallio 2006: 4), ja lisäksi lainautumissuunta.

Uralilaisia kieliä on nelisenkymmentä, kun taas indoeurooppalaisia kieliä on nelisensataa (Janhunen 2008). Näin on vain odotuksenmukaista, että indoeurooppalaisella puolella on kantakielestä periytyviä sanoja säilynyt paljon useammassa kielessä. Uralilaisella puolella sana on saattanut kadota niin monesta kielihaarasta, ettei sitä voida enää palauttaa kantakieleen.

Indoeurooppalaisia kieliä on alettu kirjoittaa jo noin 3500 vuotta sitten, uralilaisia kieliä vasta alle tuhat vuotta sitten. Tämä seikka aiheuttaa sen, että sanoilla on 
uralilaisella puolella ollut 2500 vuotta enemmän aikaa kadota taksonomisen kriteerin kannalta olennaisista kielihaaroista. Tietenkään kaikkia indoeurooppalaisia kieliä ei ole alettu kirjoittaa noin aikaisin, mutta myöhäisimpienkin indoeurooppalaisten kielihaarojen kieliä on silti kirjoitettu kauan ennen kuin vastaavasti myöhäisimpien uralilaisten kielihaarojen kieliä.

Glottokronologiassa on oletettu, että noin $14 \%$ sanastosta vaihtuisi tuhannessa vuodessa. Uralilaisten kielten yhteisestä sanastosta olisi tämän arvion mukaan ehtinyt siis kadota ehkä jopa kolmasosa sen jälkeen kun varhaisimpia indoeurooppalaisia kieliä oli jo alettu kirjoittaa mutta ennen kuin varhaisimpia uralilaisia kieliä oli alettu kirjoittaa. Tarkka arvioiminen on tietysti vaikeaa: varhaisina aikoina erillisiä uralilaisia kieliä oli paljon vähemmän kuin nykyään, joten sanan katoaminen tai korvautuminen jo jossain kantamurteessa merkitsee, että se puuttuu suuresta joukosta nykykieliä. Lisäksi on vaikeaa ellei mahdotonta erottaa vain yhdessä tai muutamassa kielessä säilyneet sanat nuorista sanoista: ei tiedetä, ovatko sanat alkuaan kantauralilaisia ja sattumalta vain kadonneet tai syrjäytyneet useimmista tytärkielistä.

Koska indoeurooppalaisia kieliä on tutkittu moninkertaisella volyymilla uralilaisiin kieliin verrattuna, tuntuu uskottavalta, että kaikkia kantauralilaisia sanoja ei ole vielä löydetty. Edistystä tässä suhteessa tapahtuu jatkuvasti, kun yhä useamman sanan levinneisyys täydentyy ja samalla ikäys varhenee (esim. Aikio 2002, 2006a; Saarikivi 2007).

Uralilaiset ovat jatkuvasti lainanneet sanoja eteläpuolellaan asuvilta indoeurooppalaisilta, ja osa sanoista on todennäköisesti korvannut vanhan uralilaisen sanan: esimerkiksi itämerensuomeen on lainattu balteilta niin sukulaissanastoa kuin ruumiinosien nimityksiäkin, joille on epäilemättä ollut sanat jo aikaisemmin. Itäisempiin kielihaaroihin puolestaan on lainattu runsaasti iranilaisia ja turkkilaisia sanoja. Lainasanojen tulva eri puolilla kielikuntaa on epäilemättä supistanut monen alkuaan kantauralilaisen sanan levikin niin suppeaksi, ettei sanoja voida enää palauttaa kantauraliin, vaikka ne alkuaan olisivatkin sieltä periytyneet.

Kaiken edellä esitetyn perusteella on täysin ymmärrettävää, että kantauraliin palautettavien sanojen lukumäärä jää pienemmäksi kuin kantaindoeurooppaan palautettavien. Kun eri kriteerit on saatu yhteismitallisiksi, ei ole nähdäkseni mitään syytä pitää kantauralia sanaston lukumäärän perusteella vanhempana kuin kantaindoeurooppaa, jonka hajoaminen voidaan nyttemmin perustelluimmin ajoittaa vuoden 3500 eaa. tienoille (esim. Parpola 1999).

\subsection{Omaperäisen sanaston laatu}

Sanaston laadussa on kiinnitetty huomiota erityisesti yhteisuralilaisten lukusanojen vähäisyyteen: kantauraliin voidaan palauttaa vain lukusanat '2' ja '5'. Lukusanoja aion käsitellä tarkemmin tulevaisuudessa, mutta tässä vaiheessa näyttää siltä, että kantauralissa olisi vallinnut sangen kehittynyt 5-10-järjestelmä, jossa on omat lukusanat luvuille 1-5 mutta jossa lukusanat luvuille 6-9 on muodostettu joko lukusanan ' 5 ' tai '10' pohjalta (järjestelmistä ks. Flegg 2002). Tällainen lukujärjestelmä vaati enemmän 
vaivannäköä kuin puhdas kymmenjärjestelmä, jossa luvuille 1-10 oli kullekin itsenäiset lukusanansa, ja helppokäyttöisempänä puhdas kymmenjärjestelmä onkin laajalti syrjäyttänyt hankalampia lukujärjestelmiä (mt.). Samojedin lukusanoissa on selviä uudennoksia (Salminen 2001: 388), ja koska lisäksi samojedi näyttää palautuvan itäuralilaiseen murteeseen ja koska kielessä täytyy olettaa olleen myös kaikki suurinta pienemmät lukusanat, täytyy olettaa samojedin kadottaneen alkuperäisiä lukusanojaan.

Tässä vaiheessa voidaan myös lyhyesti käsitellä sellaisia omaperäisiä sanoja, jotka eivät suoranaisesti auta kantauralin ajoituksessa mutta joilla kuitenkin on vaikutusta käsitykseen siitä, kuinka varhain esimerkiksi suomen kielen esimuotoa on voitu puhua Suomessa. Kantauralin kannalta tästä saadaan lähinnä aikaraja, johon mennessä on teoreettisesti mahdollista ja ylipäätään tarpeen olettaa uralilaisen kielen ehtineen Suomen lähialueille.

Kantauraliin voidaan rekonstruoida sana *piji 'piikivi', jota suomen pii jatkaa (Kulonen 1999). Sanaa ei ole kaikkialla helppo erottaa sanan *pini 'hammas' vastineista, mutta itämerensuomen ja samojedin sanueet voidaan yhdistää sekä äänneasunsa että merkityksensä puolesta: kantasamojediin rekonstruoidaan *pâj 'kivi' (Janhunen 1977: 112), mutta eräässä selkupin murteessa tavataan yksinomaisena merkitystä 'piikivi' (Alatalo 2004: 60). Kyseessä voi tuskin olla sattumalta samaan merkitykseen johtanut kehitys, vaan jo kantauraliin on syytä rekonstruoida sanan merkitykseksi juuri 'piikivi'.

Sanan arvo Suomen uralilaistumisen ajoittamisessa liittyy siihen, ettei piitä esiinny Suomen kallioperässä, vaan se on täällä tuontitavaraa. Piiesineitä tavataan Suomessa pääasiassa tyypillisen kampakeramiikan ajoista lähtien (noin 3900 eaa. alkaen), mutta jo hieman varhemman Säräisniemi I -keramiikan yhteydessä tavataan piiesineitä (Huurre 2004: 238). Vasta siis vuoden 4000 eaa. tienoilta alkaen kauppaverkostot ovat tuottaneet Suomeen jatkuvammin piikiveä. Suomen varhaiset asuttajat ovat myös tuoneet mukanaan piitä etelästä (Huurre 2004: 236), mutta sanan säilyminen kielessä yli 3000 vuoden ajan ilman, että sen tarkoitetta olisi ollut saatavilla, tuntuu täysin mahdottomalta.

Sana pii vastaa säännöllisesti samojedin sanaa eikä siksi voi olla lainaa sukukielistä, etenkään kun sana ei väliin jäävissä kielissä ole säilynyt. Tällä perusteella suomen kielen esimuotoa ei ole voitu puhua Suomessa ennen kuin vuoden 4000 eaa. tienoilla.

Toinen ajallisesti samoin rajaava sana on kantauralin *koxsi 'kuusi (Picea abies)' ( $>$ suomen kuusi). Tämä puu on levinnyt Suomeen idästä vasta melko myöhään: Lounais-Suomessa ensimmäiset satunnaiset siitepölyjäljet ovat suunnilleen vuoden 4000 eaa. tienoilta, mutta selvä jatkumo siitepölyn esiintymisessä alueella alkaa vasta vuoden 3000 eaa. jälkeen (Vuorela 2002: 85). Itämerensuomen sana on vokaalistoltaan hieman epäsäännöllinen (odotuksenmukainen olisi **koosi > suomen **kuosi), mutta sana ei siltikään voi olla lainaa sukukielistä: kantasaamen asu oli *kuose, ja vaikka kantamordvan asu oli *kuz, on kantamordva ajallisesti ilmeisesti liian myöhäinen kielentaso voidakseen olla lainannut sanan (esi)kantasuomeen (esimordvassakin sanassa oli *oo). 
Suomen kielen esimuoto on näiden sanojen perusteella voinut levitä Suomeen vasta aikaisintaan vuoden 4000 eaa. tienoilla. Tällainen ajoitus, jonka vahvistaa sanojen pata ja vaski todistus (ks. Kallio 2006: 4-8), sulkee mahdottomina pois kaikki sellaiset oletukset, joiden mukaan jo Etelä-Suomen alkuasuttajat vuoden 8500 eaa. tienoilla olisivat puhuneet suomen kielen esimuotoa. Kuitenkin näiden sanojen valossa uralilaisen kielen saapuminen Suomeen voitaisiin vallitsevan näkemyksen tapaan vielä yhdistää tyypilliseen kampakeramiikkaan, mutta seuraavissa luvuissa tämäkin rinnastus käy yhä epätodennäköisemmäksi.

\subsection{Arjalaisten lainasanojen todistus}

Edellä olen esittänyt, ettei ole perusteita pitää kantauralia erityisen vanhana kielentasona. Tästä eteenpäin selvittelen sitä, kuinka nuori kieli kantaurali oikeastaan voisi olla.

Parhaiten perustellun ja argumenteiltaan kestävimmän näkemyksen mukaan indoeurooppalaisen kantakielen eriytyminen on alkanut vuoden 3500 eaa. tienoilla Mustanmeren pohjoispuolisilla aroilla. Ajoituksen ja paikannuksen taustalla on paleolingvistinen analyysi, jonka tärkeimmän argumentin kulku voidaan tiivistää seuraavasti:

Tytärkielten yhteinen vaunusanasto voidaan palauttaa kantaindoeurooppaan, eikä sanasto voi olla vanhempaa kuin sanojen tarkoitteet eli vaunut osineen. Vaunut on ensimmäisinä otettu käyttöön neljännen vuosituhannen alussa eaa. Mesopotamiassa, josta innovaatio levisi erittäin nopeasti eri suuntiin. Indoeurooppalaisten otaksutaan saaneen vaunut käyttöönsä Mustanmeren pohjoispuolisilla aroilla (jonne muu sanasto luontevimmin viittaa), jonne innovaatio levisi Kaukasuksen välityksellä vuoden 3600 eaa. tienoilla, joten kantaindoeuroopan ekspansio on voinut tapahtua vasta tämän jälkeen. (Ks. esim. Parpola 1999: 183-185 viitteineen.)

Kantauraliin on jo aiemmin tiedetty omaksutun arkaaisen indoeuroopan tasoa edustavia lainasanoja, mutta arjalaiset lainasanat on katsottu omaksutun vasta kantauralin hajoamisen jälkeen. Olen kuitenkin esittänyt, että varhaisin uralilainen murreraja ei erottanut samojedia suomalais-ugrilaisista kielistä vaan ugrilais-samojedilaiset kielet suomalais-permiläisistä (J. Häkkinen 2007). Äänteellisin ja taksonomisin perustein voidaankin nyt jo kantauraliin palauttaa joukko distinktiivisesti arjalaisia lainasanoja.

Arjalaiset lainasanat on vanhastaan jaettu esi- ja kanta-arjalaiseen kerrostumaan. Esiarjalaisia ovat ne, joissa näkyvät arjalaishaaraa distinktoivat äänteenmuutokset $*_{k}^{\prime}>*_{c}^{\prime}, *_{k}>*_{c}$ (etuvokaalin edellä) ja $*_{s}>*_{s}\left(*_{r}: \mathrm{n}, *_{k}: \mathrm{n}, *_{i: \mathrm{n}}\right.$ ja $*_{u: n}$ jäljessä). Varsinaisina (myöhäis)kanta-arjalaisina lainoina pidetään sellaisia sanoja, joissa syllabiset nasaalit $*_{o}$ ja $*_{o}$ sekä $*_{e}, *_{o}$ ja $*_{a}$ lankesivat yhteen $*_{a}$ :ksi (Kallio 2006: 11). Kuvaa mutkistaa hieman se, että jo ennen mainittua viimeistä yhteistä kanta-arjalaista muutosta kanta-arja oli jakautunut kahteen murteeseen, esi-iraniin ja esi-indoarjaan. Esiarjan $*^{\prime} \dot{c}$ menetti palataalisuutensa jo esi-iranissa $\left(*^{*}>*_{c}\right)$, kun taas esi-indoarjalaisessa murteessa palataalisuus säilyi mutta affrikaatta yksinkertaistui sibilantiksi 
$\left(*^{*}{ }^{\prime}>*^{\prime}\right)$. Murteiden lopullinen ero tapahtui kuitenkin vasta mainittujen kanta-arjalaisten muutosten jälkeen: siitä eteenpäin voidaan puhua erillisistä tytärkielistä, kantairanista ja kantaindoarjasta. (Koivulehto 1999a: 220.)

Muutoksen $*_{e}, *_{o}>*_{a}$ ehdottomana takarajana pidetään vuotta 1800 eaa. (Carpelan \& Parpola 2001: 131). Vuoteen 1500 eaa. mennessä arjalaiset kielet olivat jo levinneet valtavan laajalle alueelle, vaikka olivatkin käytännössä yhä kantaarjan murteita (Kallio 2006: 20). Kun otetaan huomioon, kuinka suuri joukko äänteenmuutoksia erottaa kanta-arjan kantaindoeuroopasta (havainnollisina esimerkkeinä sanat: IE * $k^{w} e k^{w} l o s$ 'pyörä' > A *cakra | IE * k'mtóm '100'> A *ćatam), on selvää, että kanta-arjaa on puhuttu pikemminkin lähempänä vuotta 1500 eaa. kuin vuotta 3500 eaa. Kanta-arjalaiset muutokset voitaneen näin ollen melko turvallisesti ajoittaa karkeasti vuoden 2000 eaa. tienoille tai edeltävän vuosituhannen lopulle (Kallio 2006: $12-13)$.

Arjalaisten lainasanojen perusteella on mahdollista saada valaistusta myös uralilaiseen kronologiaan. Kantauralin ajoittamisen kannalta erittäin paljastavia ovat sellaiset sanat, joissa näkyy kiistatta jokin myöhäisistä kanta-arjalaisista äänteenmuutoksista ja jotka silti voidaan tässä tarkastelussa käytetyn levikkikriteerin ja äänteellisesti säännöllisen edustuksen perusteella palauttaa jo kantauraliin.

1. U *'śta '100' (Sammallahti 1988: 549 *śåtå)

LU *'śata > suomi sata $\mid$ saameP čuohti $\mid$ mordvaE śado

IU $\quad *_{\text {seta }}>$ mansi $*_{\text {süut } V \mid \text { hanti }}^{*}$ saat $\mid$ samojedi --

Muut: mari šü $\ddot{0} \mid$ udmurtti śu | komi śo | unkari száz

$\leftarrow \mathrm{A}$ *'́ata- / IA *śata- < IE *kómtó-m (Koivulehto 2001: 248)

Mansi ja mari yhdessä todistavat alkuperäisestä *e:stä. Voidaan olettaa, että lainanantajatahon ensitavun painoton $* a$ (muinaisintian śatá-m) ääntyi sen verran redusoituneena, että sen lähin substituutti oli uralilainen *e - kanta-arjassahan oli vain kolme vokaalilaatua, ${ }^{*} a,{ }^{*} u$ ja $*$, joten vokaalien reaalistuma-alueet ovat olleet paljon laajempia kuin kantauralissa. (J. Häkkinen 2007: 60-63.) Teoriassa sana voisi obinugrissa olla myös myöhäisempi iranilainen lainasana (Kallio 2006: 12); hantin *aa-edustuksen tämä ehkä selittäisikin, mutta mansin *ii yhdessä marin $u \ddot{u}$ :n kanssa todistaa jo kantauralilaisesta *e-substituutiosta.

2. U *asira 'herra, ruhtinas' (Sammallahti 1988: 542 *åsirå)

LU *asira $>$ suomi $--\mid$ saame $--\mid$ mordvaE azoro

IU *aLâra $>$ mansi *uuter, *aater $\mid$ hanti $--\mid$ samojedi --

Muut: mari - - | udmurtti uzir $\mid$ komi ozir $\mid$ unkari --

$\leftarrow \mathrm{A} *$ *asura $<$ IE * nsu- $_{\text {(Koivulehto 2001: 247) }}$

Sammallahdella (1988: 542) on kantamansin asuksi rekonstruoitu epäsäännöllinen *aater, mutta ainakin itämansin sana uutวิr palautuu kantamansin säännölliseen asuun *uuter 'sankari, ruhtinas'. Murteessa tunnetaan myös sana ootâr 'ruhtinas', joka palautuu mainittuun kantamansin asuun *aater (Steinitz 1955: 170). Levikin ja säännöllisten äännesuhteiden ( $\left({ }^{*} *_{S} \sim \mathrm{IU}{ }^{*}\right.$ ) perusteella 
sana on palautettava jo kantauraliin. Tässä sanassa *a on painollinen (muinaisintian ásurah), joten se substituoitiin uralilaisella *a:lla.

3. U *saras 'järvi' (Sammallahti 1988: $550 *$ šå/orå)

LU *saras $>$ suomi ? sarajas $\mid$ saame - - mordva--

IU $\quad *_{\text {Lara }}>$ mansi *tuur $\mid$ hanti *Laar $\mid$ samojedi --

Muut: mari - - udmurtti šur $\mid$ komi šor | unkari ár

$\leftarrow$ A *sáras (vrt. avestan zrayah) < IE *sélos (Koivulehto 1999a: 215)

Suomen sana voi äänteellisesti ja merkityksensä osalta ('myyttinen meri') hyvinkin kuulua tähän. Onhan itämerensuomeen lainattu muitakin sellaisia arjalaisia (iranilaisia) sanoja, jotka liittyvät lähinnä mytologiseen sanastoon (esim. marras, sammas $\sim$ sampo, taivas, mana, jumala; Koivulehto 1999a: 232). Toisaalta itämerensuomen sana voisi teoriassa olla myös myöhäisempi iranilainen lainasana, jolloin se sopisi mainittujen suppealevikkisten iranilaislainojen yhteyteen; avestan asu näyttäisi vastaavan täydellisesti itämerensuomen sanaa. Permiin sana on lainattu myöhemmin vielä uudestaan (udm. zareź, komi saridź), ja sieltä se on lainattu toistamiseen myös mansiin ja hantiin (Joki 1973: 349).

Kantamansin ja -hantin sanat ovat kuitenkin sekä vokaaliston että konsonantiston osalta täysin säännöllisiä, samoin unkarin asu. Näin ollen sana on joka tapauksessa niin vanha laina, että se on osallistunut kaikkiin itäuralilaisiin äänteenmuutoksiin - käytännössä se voidaan käyttämäni kriteerin perusteella siis palauttaa kantauraliin. Tältä osin ei ole merkitystä sillä, lasketaanko suomen vastine varmaksi vai ei. Painollinen $* a$ on tässäkin sanassa substituoitu uralilaisella *a:lla. Permin suhusibilantti on epäsäännöllinen.

4. U *ora 'oka, piikki' (Sammallahti 1988: $542 *$ orå)

LU *ora > suomi ora $\mid$ saameP oarri $\mid$ mordvaE uro

Muut: mari - - | udmurtti - - | komi - - | unkari ár

$\leftarrow \mathrm{A} * \bar{a} r \bar{a}<\mathrm{IE} * \bar{e} l \bar{a}$ (Koivulehto 2001: 248)

Tätä sanaa en ole toisessa yhteydessä (J. Häkkinen 2007: sanalista) palauttanut kantauraliin, koska sillä ei ole vastineita mansissa, hantissa eikä samojedissa. Mikäli kuitenkin varhaisin murreraja varmistuu suomalais-permiläisten ja ugrilais-samojedilaisten kielten väliin kuten alustavasti näyttäisi, riittäisi unkarin säännöllinen edustus osoittamaan sanan kantauralilaiseksi. Sana on ns. $o$-laina, eli arjalaisen $*_{a}: n$ substituuttina on uralilainen $*_{o}$ (näistä esim. Koivulehto 1999a: 215).

Koska arjassa ensitavun vokaali on ollut pitkä, voisi teoriassa ajatella uralilaistenkin hahmottaneen sen pitkäksi. Koska kuitenkaan pitkä vokaaliaines ei voinut esiintyä toisen tavun väljän vokaalin edellä, olisi sana käynyt läpi substituutiovaiheiden **aara $>* *$ oora $>*$ ora. Kuitenkaan muutosta *aa $>$ *oo ei ole välttämättä oletetussa suomalais-ugrilaisessa vaiheessa tapahtunut (J. Häkkinen 2007: 68-70), jolloin sana on laskettava toistaiseksi selittämättömien $o$-lainojen joukkoon. 
5. U *woxri 'vuori' (Sammallahti 1988: $551{ }^{*}$ woori)

LU *woori $>$ suomi vuori $\mid$ saame $--\mid$ mordva --

IU *woâr > mansi *waar $\mid$ hanti *woor $\mid$ samojedi --

Muut: mari - - udmurtti vir $\mid$ komi ver $\mid$ unkari --

$\leftarrow \mathrm{A} *$ aras- $/ *$ arah $<\mathrm{IE} * h_{1}$ er(H)os/es (Koivulehto 1999a: 218)

Tämäkin sana on $o$-laina: arjalainen $*^{*} a$ olisi substituoitu uralilaisella $*_{o}$ :lla. Kantauralin ja kanta-arjan asut eivät kuitenkaan vastaa toisiaan aivan täydellisesti.

6. U *serńa 'kulta' (Sammallahti 1988: 550 ?*šorńi)

LU * * salerńa $>$ suomi -- $\mid$ saame - - mordvaE sirne

IU $\quad *_{\text {LVrńa }}>$ mansi *tareń $\mid$ hanti * Loorńe $\mid$ samojedi --

Muut: mari šörtni | (udmurtti zarńi) | (komi zarńi)| unkari arany

$\leftarrow$ Iranista, vrt. avesta zaranya vs. muinaisintia híranya (Joki 1973: 250) <

IE * $\dot{g}^{h}(o) l(H)$ - (Beekes 1995: 37). Sana ei voi olla lainattu kanta-arjasta, koska sen *źh olisi substituoitu *s:1lä (Toivonen 1953: 22), jonka edustus erottuisi *s:n edustuksesta kaikissa kyseessä olevissa kielissä paitsi marissa.

Permiläiskielten sanat ovat vielä myöhäisempiä iranilaislainoja samasta sanasta; vanhoissa sanoissa vastinsarja udmurtin $a \sim$ komin $a$ tavataan vain sanassa *näki- 'nähdä' (Sammallahti 1988: 527-531), joten se ei palaudu säännöllisesti mihinkään vanhaan vokaaliin. Mansin ja hantin sanat ovat (kuten unkarinkin) osallistuneet itäuralilaisiin sibilanttimuutoksiin, mutta vokaaliston osalta ne ovat selittämättömän epäsäännöllisiä. Niiden merkityskään ei ole 'kulta' vaan 'kupari'. On kuitenkin mahdollista johtaa mordvan, marin ja unkarin sanat (joiden kaikkien merkitys on 'kulta') yhteisestä kantamuodosta.

Mordvassa on nimittäin joukko sanoja, joissa itämerensuomen ensitavun *a:ta vastaa $i$ : suomi vasara $\sim$ mordvaE viśir $\mid$ suomi vaski $\sim$ mordvaE viśkä (kirjakielessä uśke)| suomi marras : marta- mordvaE mirde. Syventymättä tässä aiheeseen riittänee mainita, että mordvan edustus ei äännesyistä voine selittyä myöhäiseksi lainaksi sen paremmin muista uralilaisista kielistä kuin indoeurooppalaiseltakaan puolelta (vasara ja marras ovat arjalaisia lainasanoja), joten mordvan $i$ voinee vanhassakin sanastossa vastata itämerensuomen *a:ta ja siten palautua kantauralin $* a$ :han tai ${ }^{*} e$ :hen, vaikkei vastaavuutta toistaiseksi osata selittää. (Sana vaski palautuu *ä:lliseen lähtöasuun, mutta mordvan edustus ei selity siitäkään lähtien.)

Marin sana puolestaan viittaa *e:lliseen lähtöasuun: tämä vokaali näyttää marissa edustuvan ö:nä tai $\ddot{u}$ :nä (Aikio 2002: 39; J. Häkkinen 2007: 60-63), kun taas lännempänä (mordva, itämerensuomi, saame) *e lankesi yhteen *a:n kanssa. Unkarissa *e edustuu $a$ :na toisen tavun väljän vokaalin edellä, joten sana on mahdollista palauttaa jo kantauralin asuun *serńa. Myös mansin ja hantin sanat ovat konsonantiston perusteella vanhoja (vrt. uudempia lainoja samasta sanueesta Joki 1973: 250). Arjalaisella puolella olettaisi tosin painotonta ensitavun $a: t a$, joka edeltävien esimerkkisanojen valossa olisi substituoitu kanta- 
uralissa *e:llä, mutta $a$ :n painollisuuskaan ei heikentäne selitystä kovinkaan paljon: vokaalilaatujahan oli kanta-arjassa vain kolme, joten painollinenkin *a on saattanut reaalistua melko redusoituneesti (uralilaisten näkökulmasta).

Äänteellisin perustein pidän täten mahdollisena vielä kanta-arjaa myöhäisemmän iranilaisperäisen sanan *serńa 'kulta' rekonstruoimista jo kantauraliin.

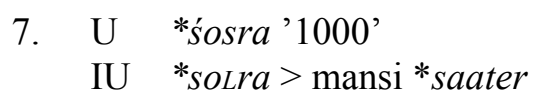

Muut: udmurtti śuris | komi śurs

$$
\leftarrow \mathrm{A} * \text { źhasra }<\text { IE *ǵheslo- (Joki 1973: 318-319) }
$$

Sanassa on peräti kaksi sibilanttia, jotka edustuvat säännöllisesti: permissä ne ovat säilyneet, mansissa ne ovat käyneet läpi itäuralilaiset sibilanttimuutokset $\left(*_{S}>\right) *_{S}>*_{L}$ ja $*_{s}^{\prime}>*_{s}$. Sanaa ei siis voi selittää lainaksi suuntaan tai toiseen, eikä sanan myöhäisempi lainautuminen iranista permiin tule vokaaliston perusteella kyseeseen (vrt. edellisen sanan nuori edustus permissä), vaan sana täytyy palauttaa jo kantauraliin. Mansin ja permin sanat voidaan selittää $*_{o}$ :sta, joten kyseessä on jälleen $o$-laina. Permissä on tapahtunut sanansisäisten konsonanttien metateesi kuten monissa omaperäisissäkin sanoissa: *meksa 'maksa', *oksi- 'oksentaa', *ükti '1', mukšV 'nyrkki', *piśla 'pihlaja', *riyiši 'riihi' jne. (Sammallahti 1988: 536-554).

Kantauralin ajoittamisen kannalta on merkittävää, että myöhäiskanta-arjalaisia lainasanoja - ja ilmeisesti jopa eriytyneistä murteista (iranilainen 'kulta', mahdollisesti indoarjalainen '100') - näyttäisi omaksutun jo kantauraliin. Sanoja on riittävästi sulkemaan pois sattuman tai myöhemmän epäsäännöllisen kehityksen mahdollisuus, ja ne ovat merkitykseltään riittävän yksiselitteisiä ja äänne-edustukseltaan säännöllisiä siinä määrin kuin vanhat perintösanat yleensäkin.

Lisäksi (varhais)kantauraliin on jo tätä aiemmin tullut esiarjalaisia lainasanoja (ks. esim. Koivulehto 2001: 247-250), ja myös kantauralin jälkeiset iranilaislainat ovat kiistattomia, joten pitkään jatkuneet kontaktit ovat tosiasia. Uutta on vain se, että vielä myöhäiskanta-arjalaisetkin sanat (tai vieläkin myöhäisemmät) olisi omaksuttu jo kantauraliin; tämä uusi tulkinta johtuu suoraan siitä, ettei varhaisinta uralilaista murrerajaa ole enää syytä sijoittaa samojedin ja muun kielikunnan väliin.

Jo aiemmin on kyllä huomattu, että osa arjalaisista lainasanoista on käynyt läpi samat muutokset kuin vanhat omaperäiset sanatkin, mutta Suomen alueen arkeologisen jatkuvuuden uskottiin vielä tuolloin olevan painava todiste kielellisenkin jatkuvuuden puolesta (tutkimushistoriasta K. Häkkinen 1996: 140-141). Arkeologinen jatkuvuus ei kuitenkaan voi luotettavasti todistaa kielellisestä jatkuvuudesta (J. Häkkinen 2006a), joten ei ole perusteltua ohittaa lainasanojen todistusta.

Perinteinen näkemys, jonka mukaan samojedi olisi eronnut uralilaisesta kieliyhteydestä ensimmäisenä, on yhdessä sen tosiseikan kanssa, että samojedista ei ole toistaiseksi löytynyt kielikunnassa muuten laajalevikkisiä kanta-arjalaisia lainasanoja, estänyt palauttamasta kanta-arjalaisia lainasanoja kantauraliin. Nyt kun äänteellisin 
perustein näyttää siltä, että samojedi on eriytynyt vasta itäuralilaisesta murteesta, voidaan olettaa myös arjalaisten lainasanojen kadonneen kielestä myöhemmin - onhan samojedi vaihtanut massiivisessa mitassa jopa sellaista perussanastoa, jonka aiempaa läsnäoloa kielessä ei mitenkään voida epäillä (uralilaiset sanat 'pää', 'suu', 'hammas', 'kaula', 'käsi', 'jalka', 'veri', 'suoni', 'suoli' jne.).

Lisäksi samojedin *wåtå- 'kasvattaa' näyttää olevan kanta-arjalainen lainasana $(<\mathrm{A} *$ wakš-(aya-); ks. Aikio 2002: 52), mikä todistaa, että myös samojedissa on sittenkin kanta-arjalaisia lainasanoja, jotka ovat osallistuneet itäuralilaisiin sibilanttimuutoksiin. Vaikka samojedilla ei toistaiseksi näytä olevan muiden kielihaarojen kanssa yhteisiä kanta-arjalaisia lainasanoja, niin kanta-arjalaisten lainasanojen omaksumisajan täytyy joka tapauksessa olla yhtä varhainen kuin muuallakin. Koska suurin osa esimerkiksi unkarin iranilaisista lainasanoista on lainattu vasta itäuralilaisten sibilanttimuutosten jälkeen, ovat nuo muutokset tapahtuneet melko pian kantaarjalaisten lainasanojen omaksumisen jälkeen. On vaikea nähdä, että samojedissa nuo muutokset voisivat olla myöhäisempiä kuin ugrilaisissa kielissä, kuten alumpana tarkastelua perustelin.

Kanta-arjalaisten lainasanojen todistus on yksiselitteinen: kantaurali ei ole voinut merkittävästi hajota alueellisesti eikä kielellisesti ennen myöhäiskanta-arjalaisten lainasanojen omaksumista. Koska kanta-arjalaiset muutokset ovat tapahtuneet vasta suunnilleen kolmannen vuosituhannen lopulla eaa., ei kantauralin hajoaminenkaan ole voinut tapahtua ennen vuotta 2000 eaa. (hyvin karkeasti arvioiden).

\subsection{Metallinnimitysten todistus}

Suomen vaski-sanaa vastineineen on pidetty todisteena siitä, että kantauralin aikaan olisi jo tunnettu metalli. Kuitenkin vallitsevan käsityksen mukaisiin ajoituksiin suhteuttaen ja läntisten kielihaarojen merkitykseen 'kupari' vedoten on ajateltu, että sana olisi voitu omaksua jo kivikaudella, jolloin kupariesineitä jo liikkui laajalti pohjoisessa Euroopassa (Salminen 1999: 22). Niinpä vaski-sanue ei yksin vielä autakaan kantauralin ajoittamisessa, vaikka se toki auttaa sulkemaan pois uralilaisen ekspansion kaikkein varhaisimmat ajoitukset (ks. Kallio 2006: 8).

Ajoituksen kannalta kiinnostavampi onkin toinen metallinnimitys: udmurtti uzveś 'tina, lyijy' komi ozỉś 'tina' mansi N ātwâs, LM ååtwâš, LU aatwâš, P oåtwâš, K oåtkhwâs, T äitkhuś 'lyijy' (< mansi *äätwâs). Yhdyssanan loppuosana on mainittu vaski-sana ( ${ }^{*}$ wäśka), mutta alkuosa ei ole mikään vanhastaan tunnettu sana. Ensikomponentin osalta mansin sana palautuisi säännöllisesti kantauralilaiseen lähtöasuun *äs $V$, kun taas permin asu palautuisi säännöllisesti kantauralin asuun *esa (Sammallahti 1988: 530). Kuitenkin samanlaista edustusta tavataan permissä

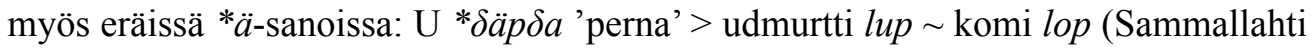
1988: 543) | U *päyi 'pää' > udmurtti puy komi pon (Sammallahti 1988: 548). Alkukomponentin alkuperäiseksi vokaaliksi voidaankin rekonstruoida *ä. Koska myös konsonanttivastaavuus on säännöllinen (permin $s \sim \operatorname{mansin} t$ ), voitaisiin yhdyssanan alkuosa rekonstruoida jo kantauraliin asuun * äsa. 
Yhdyssanan loppuosana esiintyvä sana *wäśka on yleensä palautettu kantauraliin, vaikka siinä vokaaliston osalta onkin paljon epäsäännöllisyyttä. Sanan rekonstruoinnin kannalta on kuitenkin syytä keskittyä niihin kielihaaroihin, missä sana on säilynyt itsenäisenä: saameen, itämerensuomeen, mordvaan, unkariin ja samojediin. Sen sijaan sattumoisin juuri permissä ja mansissa sanan vastine on säilynyt vain yhdyssanojen jälkiosana. Voitaneen perustellusti olettaa, että jälkitavuihin joutuneet vokaalit ovat näissä kielihaaroissa altistuneet kulumiselle ja poikkeavalle kehitykselle verrattuna ensitavun vokaaleihin; siksi lähtöasua rekonstruoitaessa voidaan näiden kielihaarojen edustus ohittaa. Saamen ja samojedin edustuksen perusteella säännölliseksi asuksi voidaankin rekonstruoida *wäśka, ja itämerensuomen *vaski voidaan säännöllisen epäsäännöllisenä palauttaa samaan lähtömuotoon, vrt. ims. *talvi < $\mathrm{U}$ *tälwa $\mid$ ims.

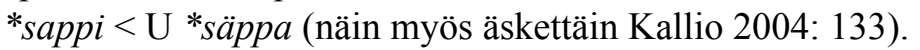

Sanan *wäśka kohdalla permiläisten kielten vokaalivastaavuus udmurtti $e$ komi $i$ ei palaudu säännöllisesti mihinkään alkuperäiseen vokaaliin, mikä lienee selvä osoitus jälkitavujen vokaaleja koskeneesta kulumisesta. Myöskään mansin redusoitunut vokaali ei tässä asemassa kerro paljonkaan vokaalin alkuperäisestä laadusta. Koska kuitenkin muiden kielihaarojen perusteella jo kantauraliin voidaan palauttaa sana *wäs'ka 'kupari tai pronssi' ja koska permin ja mansin sanat muistuttavat tätä sanaa konsonantistonsa ja merkityksensä puolesta, voitaneen aikaisemman tutkimuksen tapaan pitää permin ja mansin sanoja samaan yhteyteen kuuluvina vaikkakin jälkitavuihin jouduttuaan epäsäännöllisesti kuluneina. Myös tässä sanassa sibilantti-

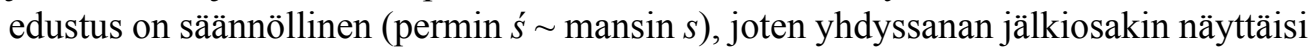
periytyneen näihin kieliin jo kantauralista.

Voidaanko koko yhdyssana merkityksessä 'tina' tai 'lyijy' sitten palauttaa jo kantauraliin? Yksinomaan levikin perusteella tämä olisi epävarmaa, koska sana on säilynyt vain alueellisesti suhteellisen läheisissä kielihaaroissa oletetun varhaisimman uralilaisen murrerajan molemmin puolin. Äänteellisten kriteerien perusteella sen sijaan ollaan varmemmalla pohjalla. Ensiksikin sanan alkuosa voidaan rekonstruoida uskottavasti asuun * $\ddot{s} a$, ja vaikka jälkiosa onkin juuri yhdyssanan tuntevissa permissä ja mansissa kehittynyt epäsäännöllisesti, edustaa se epäilemättä kantauralin *wäśkasanaa. Mikä tärkeintä, yhdyssanassa on peräti kaksi erilaista sibilanttia, joiden edustus on säännöllinen: permissä sibilantit $*_{s}$ ja $*_{s}^{\prime}$ ovat säilyneet, kun taas mansissa ne ovat osallistuneet säännöllisiin itäuralilaisiin muutoksiin: $U *_{S}>\mathrm{IU} *_{L}>$ mansi $*_{t}$ ja $U *_{S}>$ IU $*_{S}>$ mansi $*_{S}$. Näillä perusteilla sanaa ei oikein mitenkään voida pitää lainana sen paremmin permistä mansiin kuin toiseenkaan suuntaan, vaan yhdyssana *äsa-wäśka on rekonstruoitava jo kantauraliin.

Sekä tinaa että lyijyä käytettiin pronssin sekoiteaineena: lyijypronssista (jossa lyijyä oli jopa $10 \%$ ) oli helpompi valaa pieniä, tarkkoja yksityiskohtia sisältäviä esineitä (esim. koruja), mutta pehmeämpänä lyijypronssi ei sopinut aseisiin eikä työkaluihin (Jordan 2008). Niinpä sanan * äsa-wäśka alkuperäinen merkitys on voinut olla joko 'tina' tai 'lyijy', tai peräti 'tina tai lyijy' - joka tapauksessa nimityksellä on viitattu pronssin vähäisempään sekoiteaineeseen.

Kuparimalmia on osattu hyödyntää jo kivikaudella, mutta pronssia ei luonnollisestikaan ole osattu valmistaa ennen kuin vasta varsinaisella pronssikaudella. 
Siinä missä kauempana metallurgisista keskuksista asuvat kansat ovat voineet kutsua pronssia ja kuparia - ja miksei muitakin metalleja - yhdellä ja samalla nimellä, ovat metallurgiaa tuntevat kansat epäilemättä tienneet ja tehneet eron raaka-aineiden ja lopputuotteen välillä. Ei liene sattumaa, että tässä käsitelty erillisen sekoitemetallin nimitys on säilynyt juuri permissä ja mansissa, joiden ammoiset puhuma-alueet ovat olleet Etelä-Uralin ja Kaman alueen rikkaan metallurgisen keskuksen välittömässä läheisyydessä (ks. kartta Carpelan \& Parpola 2001: 99).

Mielenkiintoista kyllä, tämän sanan kanssa on levikin osalta täydennysjakaumassa toinen 'tinaa tai lyijyä' merkitsevä sana: mari wulnô 'tina' | hanti ùtân, olna 'lyijy' | unkari ón, vanh. olno 'tina' (Toivonen 1953: 14). Sanalla on kyllä vastine myös mansissa, mutta siellä sen merkitys on 'hopea; kulta; raha'; ainakin sanan merkitys lieneekin mansissa myöhäisempi. Näiden kahden sanueen levinneisyysero selittynee sillä, että rikkaalla malmialueella asuvat esipermiläiset ja esimansit lienevät hallinneet pronssimetallurgian ja käyttäneet pronssin vähäisemmästä sekoiteaineesta nimitystä *äsa-wäśka, kun taas läntisemmät ja itäisemmät kantauralilaiset heimot tai klaanit, jotka asuivat kauempana metallurgisista keskuksista, olisivat saaneet metalliesineitä käsiinsä valmiina tuotteina: punertavaan metalliin (kupari, pronssi, myöhemmin rauta) olisi viitattu sanalla *wäśka ja sinertävään metalliin (tina, lyijy) sanalla *olna tai *olni (jälkimmäinen on Sammallahden [1988: 542] rekonstruktio).

Oliko sitten sanan U *wäśka alkuperäinen merkitys 'kupari', jolloin sanan U *äsa-wäśka kirjaimellinen merkitys olisi ollut esimerkiksi "vähäkupari" (sekoiteainetta tarvittiin vain noin kymmenesosa kuparin määrästä), vai oliko sanan *wäśka merkitys 'pronssi', jolloin sanan *äsa-wäs'ka kirjaimellinen merkitys olisi ollut esimerkiksi "osapronssi" (toinen pronssiseokseen tarvittava aine)? Tähän on mahdotonta tässä vaiheessa löytää vastausta. Mutta olipa *wäska-sanan alkuperäinen merkitys kumpi tahansa ('kupari' tai 'pronssi'), niin jo yksin se seikka, että tinaa tai lyijyä merkitsevä sana on yhdyssana, todistaa aukottomasti, että nimityksen on motivoinut pronssinvalmistusprosessi. Vain pronssimetallurgian tuntemus on voinut aiheuttaa sen, että tinan tai lyijyn nimitys on muodostettu yhdistämällä kuparia tai pronssia merkitsevästä sanasta. Tina ja lyijy olisi toki metalleina voitu tuntea jo aikaisemmin, mutta niiden yhteyttä pronssiin ja kupariin ei ole mitenkään voitu tuntea ennen pronssikautta ja pronssimetallurgiaan tutustumista.

Vaikka teoriassa metallin nimitys olisikin voitu tuntea jo ennen metallurgisen taidon omaksumista esimerkiksi kauppakontaktien seurauksena, ei tällainen oletus ole uskottava sanan *äsa-wäs'ka 'tina tai lyijy' kohdalla: metallurgiaa tuntematon kansa ei olisi tarvinnut tällaista yhdysnimitystä. Olennaista kantauralin ajoituksen kannalta onkin nyt selvittää, milloin pronssimetallurgia levisi Etelä-Uralille. Christian Carpelanin ja Asko Parpolan mukaan Abaševon kulttuuri levisi kolmannen vuosituhannen eaa. viimeisellä neljänneksellä Keski-Volgan tienoille, missä syntyi konflikti Balanovon kulttuurin kanssa alueen rikkaiden kupariesiintymien hallinnasta. Toiselle vuosituhannelle eaa. tultaessa metsävyöhykkeellä alkoi pronssikausi, ja vuoden 1800 eaa. tienoilla pronssikaupan monopolin otti haltuunsa Seiman-Turbinon transkulttuurinen kauppaverkosto, jonka lienevät panneet alulle osaavat Abaševon kulttuurin metallurgit. (Carpelan \& Parpola 2001: 95-111.) 
Näin pronssin sekoitemetallin nimitys todistaa täsmälleen samaa kuin myöhäiskanta-arjalaiset lainasanatkin: kantaurali on ollut vielä yhtenäinen, suhteellisen suppea-alainen kieli pronssikauden alkaessa pohjoisessa, eli suunnilleen kolmannen ja toisen vuosituhannen eaa. vaihteessa.

Mielenkiintoista olisi myös selvittää tässä esitetyn yhdyssanan alkuperä; Petri Kallio on äskettäin käsitellyt sanaa *wäśka ja päätynyt siihen tulokseen, ettei sanan alkuperä löydykään indoeurooppalaiselta puolelta (Kallio 2004: 133; 2006: 7). Sen sijaan yhdyssanan alkuosaa *äsa ei liene aikaisemmin edes tutkittu, mutta se ei näyttäisi muistuttavan mitään tunnettua uralilaista sanaa. Toistaiseksi siis yhdyssanan kummankin osan alkuperä on täysi arvoitus. On kuitenkin epätodennäköistä, että yhdyssana olisi lainattu sellaisenaan. Koska nimittäin *wäśka-sanaa käytetään osassa uralilaisia kieliä vain itsenäisenä metallinnimityksenä ja osassa vain yhdyssanan perusosana, kun taas * $\ddot{a} s a$-sanaa tavataan vain suppealla alueella yhdyssanan osana, täytynee olettaa *wäśka-sanan olleen kielessä aikaisemmin. Eli vaikka kumpikin osa olisi lainaperäinen, olisi *wäśka lainattu aikaisemmin ja *äsa vasta kantauralin myöhäisvaiheessa, jolloin pronssimetallurgian omaksuminen kasvatti tinan ja lyijyn tarvetta. Lainalähteenä on saattanut olla jokin sittemmin kadonnut paleosiperialainen tai keskiaasialainen kieli.

Edellisessä luvussa 3.3 esitetty kantauralilainen sana *serńa 'kulta' ei sen sijaan merkityksensä osalta merkittävästi auta kantauralin ajoittamisessa. Kultaa on käytetty jo neljännellä vuosituhannella eaa., ja sitä merkitsevä sana on rekonstruoitu jo kantaindoeurooppaan (Beekes 1995: 37). Tämän uralilaisen sanan todistusvoima ei riipukaan kielenulkoisesta todellisuudesta vaan lainanantajakielen (varhainen iranilainen kielimuoto) ajoituksesta.

\subsection{Maataloussanaston todistus}

Uralilaisissa kielissä ei ole kovinkaan paljon laajalevikkisiä maatalouselinkeinoihin liittyviä sanoja. Jokunen voidaan kuitenkin esittää:

1. U *oxči (Sammallahti 1988: $552 *$ uuči [FP])

$>$ LU *ooči > suomi uuhi $\mid$ saame - - | mordvaE uča

$>$ IU *ô̌c > mansi *aaš | hanti *aač $\mid$ samojedi - -

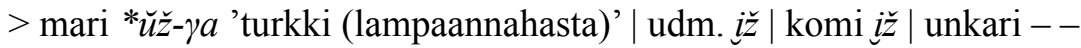

Sanan vokaalistossa on epäsäännöllisyyksiä: mari ja itämerensuomi viittaavat alkuperäiseen ensitavun $* u$ :hun, ja myös permi voidaan johtaa siitä, mutta mordva ja mansi viittaavat alkuperäiseen $*_{o}$ :hon (hantin vokaali on epäsään-

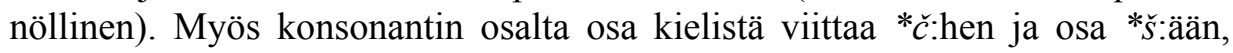
joten sanan epäsäännöllisyys asettaa sanan kantauralilaisuuden kyseenalaiseksi. Laajan levikin, yhtenäisen merkityksen sekä mordvan ja mansin asujen äänteellisen yhteensopivuuden vuoksi sanaa voitaneen kuitenkin pitää kantauralilaisena, vaikka eräissä kielihaaroissa se voikin olla sekundaari. 
2. U *woxji 'voi' (Sammallahti 1988: $551 *$ wooji)

$>$ LU *wooji > suomi voi $\mid$ saameP vuodja $\mid$ mordva $o j$, vaj

$>$ IU *wồj > mansi *waaj $\mid$ hanti *wooj $\mid$ samojedi - -

$>$ mari *üj|udm. vej| komi vij | unk. vaj

Merkitys 'voi' on tunnettu kaikissa kielissä, vaikka esim. SSA nimeääkin alkuperäiseksi merkitykseksi 'rasvan' - ilmeisesti vain siksi, että kantauralia on pidetty liian varhaisena kielimuotona voidakseen tuntea maataloussanastoa. Sanalle on esitetty varhaiskanta-arjalainen originaali (Koivulehto 1999a: 217).

Suppeampilevikkisiä mutta äänteellisin perustein jo kantauraliin palautuvia voivat olla seuraavat Toivoselta (1953: 19) poimitut sanat. Koska näille sanoille ei löydy rekonstruktiota Sammallahden (1988) sanalistasta ja UEW:n rekonstruktiot ovat astetta epämääräisempiä, esitän kunkin kielen kohdalla murre-edustuksen ja sen pohjalta omat rekonstruktioni.

3. U *̌senti 'vehnä/ohra'

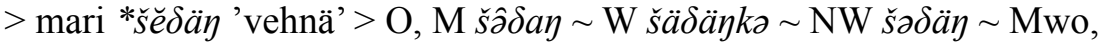

$$
\begin{aligned}
& \text { Mup } \check{s} \breve{\delta} \delta a \eta \\
& >\text { komi *šogdi 'vehnä' > V, S, I Le šobdi L ̌̌obi P šogdi } \\
& >\text { IU * Lentô 'ohra, vilja' } \\
& >\text { unkari ed 'vilja' } \\
& >\text { hanti *Länt 'ohra, vilja' }>\text { DN tänt } \sim \mathrm{V} \text { länt } \sim \mathrm{Vj} . \text { jänt } \sim \text { Trj. Lant }
\end{aligned}
$$

Sana on konsonantiston osalta helposti rekonstruoitavissa: marissa on tapahtunut melko tavallinen konsonanttien metateesi, komissa denasalisaatio (velaarisuus säilynyt), unkarissa ja hantissa nasaalin dentaaliassimilaatio. Unkarin ja hantin sanat ovat osallistuneet vanhaan itäuralilaiseen muutokseen $*_{s}>*_{L}$, ja unkarin sanassa näkyy säännöllinen muutos $*_{n t}>*_{d}$. Vokaaliston osalta mari viittaa ensitavun *e:hen (vain länsimarissa on epäsäännöllinen $\ddot{a}$ ), ja kaikkien muidenkin kielten sanat voidaan johtaa säännöllisesti *e:stä. Toisen tavun vokaalin laatua ei voi kyseessä olevien kielihaarojen perusteella varmasti määrittää, mutta komin $o$ viittaa alkuperäiseen toisen tavun *i:hin (Sammallahti 1988: 531).

Sanan merkitys on lännessä 'vehnä', idässä 'vilja, ohra'; mainitut viljalajit kuuluvat pohjoisen Euroopan varhaisimpiin viljakasveihin, joten olipa sanan alkuperäinen merkitys kumpi tahansa, on tässä mahdollinen todiste kantauralilaisten maanviljelyksestä.

4. U *puśnV'jauho'

$>$ udm. piź

$>$ komi piź

$>$ mansi pasen

Sana voidaan palauttaa säännöllisesti asuun *puśnV, eikä se sibilanttivastaavuuden vuoksi voi olla myöhempää lainaa suuntaan tai toiseen. Sanalla 
on oletettu viitatun myös villikasvien siemenistä jauhettuun jauhoon, joten se ei välttämättä todista maanviljelystä (ks. K. Häkkinen 1999: 166). Vaikka jauhoja on saatettu myös ostaa valmiina naapureilta, on vähintäänkin lähialueilla täytynyt asua viljelijöitä. Sanan epäuralilainen konsonanttiyhtymä viittaa laina-alkuperään.

Maataloussanaston arvo kantauralin ajoituksessa riippuu suoraan sen puhuma-alueen paikannuksesta: mitä etelämpänä kantauralia on puhuttu, sitä varhaisempi sen ajoitus voisi maataloussanaston perusteella olla. Ja vastaavasti kantauralin paikannukseen maataloussanastolla on suuri vaikutus, koska se sulkee pois pohjoisimmat metsäseudut, joille maanviljelys on levinnyt vasta erittäin myöhään jos ollenkaan, samoin kuin tietysti tundran, jolla viljelyä ei edelleenkään harjoiteta.

Aron ja metsäaron/lehtimetsän välinen raja kulkee Samarajoella, hieman Volgan mutkan eteläpuolella, jatkuen täältä länsilounaan suuntaan. Tämä raja on ollut hyvin pitkään myös jyrkkä kulttuuriraja, ja indoeurooppalaista kantakieltä on etsittävä jostain rajan eteläpuolelta, uralilaista kantakieltä sen pohjoispuolelta. Tarkemmin kantauralin paikannukseen palataan myöhemmin, mutta tässä vaiheessa on maataloussanaston todistusta verrattava kielenulkoiseen maailmaan pitäen silmällä sitä ajankohtaa, jolloin maatalouselinkeinot näyttävät levinneen kyseisen jyrkän kulttuurirajan pohjoispuolelle, missä vasta kantauralin puhujat ovat voineet niihin tutustua. David W. Anthonyn mukaan karjatalous (josta todistavat kantauralin sanat 'voi' ja 'uuhi') levisi rajan pohjoispuolelle vasta aikaisintaan 2500 eaa. (Anthony 2001). Maanviljely alueella on vielä myöhäisempää: Samarajoen laaksosta rajan eteläpuoleltakin on varmoja merkkejä viljanviljelystä vasta toiselta vuosituhannelta eaa. (Anthony \& Brown 2008).

Maataloussanasto osoittaa näin, että kantaurali on ollut suppea-alainen ja yhtenäinen kielimuoto vielä vuoden 2000 eaa. tienoilla.

\subsection{Yhteenveto ajoituksesta}

Toisin kuin on esitetty (esim. Janhunen 2008), kantauraliin palautettava sanasto ei nähdäkseni sen paremmin määränsä kuin laatunsakaan perusteella viittaa erityisen varhaiseen kielentasoon. Päinvastoin arjalaiset lainasanat, pronssin sekoitemetallin nimitys ja maataloussanasto osoittavat, että kantaurali oli vielä pohjoisen pronssikauden alkaessa eli suunnilleen vuoden 2000 eaa. tienoilla yhtenäinen, suppealla alueella puhuttu kielimuoto. 


\section{Kantauralin paikannus}

\section{I. Puhuma-alueen päätteleminen puuttuvien sanojen avulla}

Tämän osion luvuissa käsittelen kohtia, joissa kantakielen sanaston perusteella tehdään päätelmiä puhuma-alueesta. Aluksi kuitenkin käsittelen tapausta, jossa kantakielen tietyn aihepiirin sanaston puuttumisesta voidaan varovasti tehdä joitain päätelmiä.

Toisinaan (esim. Korhonen 1984) vedotaan siihen, että kantauralin puhuma-alue on ollut sisämaassa, koska esimerkiksi sellaiset sanat kuin meri, salo 'saari', niemi, lahti, salmi, saari, hylje, valas, lohi ja ankerias (kaksi viimeistä merikaloja) on lainattu kantasuomeen pääasiassa balteilta (mainituista vain niemi, salmi ja saari ovat tuntematonta alkuperää, hylje ja valas mahdollisesti germaanista, ja muille on ainakin esitetty balttilainen etymologia). On myös vastattu, että sanojen laina-alkuperä ei sinänsä todista, etteikö vastaavanmerkityksisiä sanoja olisi voinut olla kielessä myös ennen kuin lainasanat ne syrjäyttivät. Kielikunnan laajuinen vertailu kuitenkin paljastaa, onko tällaisille tarkoitteille ollut aiemmissa kielivaiheissa sanoja vai ei.

Esimerkiksi itämerensuomeen on balteilta lainattu myös sanat hammas ja kaula, vaikka näille tarkoitteille on ollut omaperäisetkin sanat, kantauralin *pini ja *śspa. Lisäksi nämä vanhat perintösanat elävät kielessä edelleen, joskin lainasanojen marginaaliin sysääminä: pii esiintyy mm. merkityksessä 'haravan piikki/hammas' ja sepä merkityksessä 'reen ylöspäin kaartuva etuosa' (ja johdoksena sepalus). Samoin vaikka itämerensuomen sana jänis on tuntematonta alkuperää, ei suinkaan voida väittää, etteivät kantasuomalaiset olisi tunteneet jänistä ennen tämän sanan lainaamista, koska jo kantauraliin voidaan rekonstruoida sana *ńoma(la) 'jänis', joka on säilynyt niinkin lähellä kuin saamessa: njoammil.

Kantauraliin ei kuitenkaan voida rekonstruoida lainkaan sanoja tarkoitteille 'meri', 'saari', 'niemi', 'lahti', 'salmi', 'hylje', 'valas', '(meri)lohi' ja 'ankerias', vaan sanat näille käsitteille on lainattu tai muodostettu myöhemmin erikseen eri uralilaisiin kieliin. Koska kantauralissa kuitenkin oli sanat perusasioille kuten hampaalle, kaulalle, päälle, jalalle, kädelle, suulle, silmälle, maksalle ja sydämelle, samoin kuin sanat monille eläimille, kasveille, puille, vedelle, jäälle, joelle ja järvelle, voidaan hyvinkin pitää merkittävänä sitä, että kantauralissa ei ollut sanoja merelliseen ympäristöön liittyville maastokohteille eikä merikaloille.

Ei liene uskottavaa olettaa, että jostain syystä juuri merellisen aihepiirin sanat olisivat myöhemmin kadonneet tai joutuneet lainasanojen syrjäyttämiksi, vaan voidaan pikemminkin olettaa, että kantauralin puhujat eivät tunteneet merta. Voi toki olla, että esimerkiksi mereen on viitattu samalla sanalla kuin järveenkin, mutta silti jää selittämättä, miksei kantauralissa ole ollut mitään muitakaan mereen liittyviä sanoja (Korhonen 1984: 62-63). Kantauralin puhuma-alue ei siis suurella todennäköisyydellä ole sijainnut meren rannalla eikä edes kovin lähellä merta, koska tällöin nimityksiä merellisille asioille olisi todennäköisesti lainattu naapurikansoilta jo kantauraliin. 
Kantauralin puhuma-aluetta on siis etsittävä väljästi rajaten jostakin pohjoisen Euraasian sisämaasta; seuraavissa luvuissa pyritään rajaamaan tämä alue askel askelelta tarkemmaksi.

\subsection{Geologiset ja ekologiset vyöhykkeet}

Elinympäristö, johon kuuluvat niin geologiset kuin ekologisetkin tekijät, näyttää olevan suhteellisen pysyvä ja muuttumaton sekä kielikunnan mitassa kaikkia uralilaisia kansoja yhdistävä tekijä. Elinkeinoista maanviljely on jo varhain levinnyt lehtimetsää kasvaville keveille savimaille, kun taas havumetsävyöhykkeellä pyyntitalous on säilyttänyt tärkeytensä monin paikoin viime vuosisatoihin saakka. Suurinta osaa uralilaisen kielikunnan puhuma-alueesta luonnehtii edelleen elinympäristö, joka geologisesti katsoen on runsaiden jokivesistöjen halkomaa alankomaata, ekologisesti katsoen Pohjois-Euraasian havumetsävyöhykettä eli taigaa.

Uralilainen kielikunta kattaa idässä historiallisesti lähes koko Länsi-Siperian alangon (eteläosia lukuun ottamatta) mutta ei mittavasta ekspansiivisuudestaan huolimatta ole onnistunut leviämään Jenisein itäpuolelle, jossa välittömästi kohoaa laaja Keski-Siperian ylänkö. Jenisein itäpuolelle uralilainen kieli on onnistunut leviämään vain aivan pohjoisessa: samojedihaaraan kuuluvaa nganasania puhutaan Taimyrin niemimaalla. Tämä alue on Pohjois-Siperian alankoa, joka on elimellisesti jatkoa Länsi-Siperian alangolle: se muistuttaa geologisesti Jenisein länsirannalta Itämerelle ulottuvaa uralilaista alankoaluetta. Voidaan siis sanoa, että uralilainen kieli on onnistunut leviämään Pohjois-Euraasiassa kaikkialle, missä on jokien halkomaa alankoa. Tällaista ympäristöä voidaan siis pitää tyypillisesti "uralilaisena" siinä mielessä, että myös kantakielen puhuma-aluetta on etsittävä tällaiselta alueelta.

Ainoastaan kielikunnan kaakkoisimmassa ja luoteisimmassa ääripäässä on tapahtunut varsin myöhään siirtyminen geologisesti erilaiseen ympäristöön: sajaninsamojedit siirtyivät Sajanin vuoristoon ja saamelaiset pohjoisen Fennoskandian tunturialueelle. Saamen puhuma-alueen siirtyminen pohjoiseen on ajoitettu paleoeurooppalaisten substraattilainojen ja germaanisten lainasanojen avulla ajanlaskumme ensimmäisille vuosisadoille (Aikio 2004), eikä eteläisimpien samojedikielten siirtyminen ylänköalueille liene tapahtunut ainakaan kovinkaan paljon tätä varhemmin (kantasamojedin hajoaminen ajoitetaan karkeasti hieman ajanlaskun alkua varhaisemmaksi; Janhunen 1998: 476).

Näitä myöhäisiä poikkeuksia lukuun ottamatta yhäkin geologisesti sangen yhtenäisellä uralilaisen kielikunnan puhuma-alueella voidaan kuitenkin ekologisesti erottaa erilaisia vyöhykkeitä. Unkarilaiset ovat ainoa uralilainen ryhmä, joka kiistatta on siirtynyt metsävyöhykkeeltä etelään vilkkaasti liikennöidylle ja varsinaisia kansainvaelluksia mahdollistaneelle arovyöhykkeelle. Obinugrilaisten on myös oletettu asuneen jonkin aikaa arovyöhykkeen lähistöllä, mutta vyöhykkeiden siirtyillessä ilmastosyklien mukaan heistä tuli taigan asukkaita (Fodor 1975: 70).

Tundralle on levinnyt uralilaisia kieliä puhuvia ryhmiä vasta viimeisten kahdentuhannen vuoden aikana: pohjoissamojedeja ja saamelaisia hieman aikaisemmin, komeja ja obinugrilaisia vasta myöhemmin. Erityisesti tundranenetsin kieli on ollut 
ekspansiivinen: kielialue ulottuu Luoteis-Siperiasta Tazjoelta Kaninin niemimaalle Vienanmeren äärelle. Vielä 1500-luvulla läntisimmällä tundralla uskotaan asuneen tuntematonta varhaisempaa väestöä, joka sittemmin vaihtoi kielensä tundranenetsiin (Salminen 1999: 18).

Uralilaisten kansojen varhaisin asutusvyöhyke on siis ollut aron ja tundran väliin jäävä leveä metsävyöhyke (tai osa siitä). Metsävyöhykekin voidaan jakaa kahtia pohjois-itäiseen taiga- eli havumetsävyöhykkeeseen ja lounaiseen lehtimetsävyöhykkeeseen (käytännössä pääosin sekametsää, mutta jaloja lehtipuita esiintyy). Lehtimetsävyöhykkeen pohjoisraja kulkee nykyään Etelä-Suomesta Laatokan kautta Ylä- ja Keski-Volgaa seuraten Volgan mutkaan ja kaartaa sen itäpuolella etelään Samaran tienoille, jossa raja muuttuu aron vastaiseksi etelärajaksi ja kääntyy EteläUralilta lounaan suuntaan. Satunnaisesti lehtimetsävyöhykkeen puita (tammea, jalavaa, vaahteraa, saarnea ja pähkinäpensasta) saattaa esiintyä myös varsinaisen vyöhykkeen pohjoispuolella jäänteinä esihistoriallisilta lämpökausilta.

Havumetsävyöhykkeen väestöt ovat säilyttäneet hyvin myöhäisiin aikoihin vanhat metsästys- ja keräilyelinkeinonsa, kun taas lehtimetsävyöhykkeelle ja sen välittömään läheisyyteen siirtyneet väestöt ovat omaksuneet jo suhteellisen varhain karjatalouden ja maanviljelyn. Puhtaimmin lehtimetsävyöhykkeelle ovat siirtyneet itämerensuomalaiset ja mordvalaiset (samoin kuin näiden välissä asuneet ja myöhemmin kadonneet uralilaiset kansat), mutta myös Etelä-Suomen varhaiset (esi)saamelaiset sekä Volgan ja Kaman yhtymäkohdan ympäristössä marit ja udmurtit ovat omaksuneet maatalouden jo suhteellisen varhain eläessään lehtimetsävyöhykkeen ja taigavyöhykkeen vaihettumisalueilla.

Kantauralin puhuma-alue on siis sijainnut suurimmalla todennäköisyydellä Pohjois-Euraasian sisämaassa (ks. edellinen luku), havumetsävyöhykkeellä jossakin Ylä-Volgalta Länsi-Siperiaan ulottuvalla runsasjokisella alankomaalla. Seuraavissa luvuissa puhuma-aluetta pyritään rajaamaan yhä tarkemmin.

\subsection{Varhaisimman murteutumisen alue}

Varhaisimman murteutumisen alue on suurella todennäköisyydellä myös kantakielen puhuma-alue, vaikka automaattisesti tämä sääntö ei kuitenkaan päde (ks. Kallio 2002: 31). Uralilainen kielikunta on kuitenkin historiallisesti erittäin tiivis ja yhtenäinen (aukot kartalla johtuvat myöhäisistä tapahtumista kuten venäjän ekspansiosta) ja ennen kaikkea rakenteeltaan ketjumainen: naapurikielihaaroilla on toistensa kanssa vanhojakin yhteisiä piirteitä, joten kielihaarojen suhteellinen sijainti lienee ollut aina sama. Voidaankin suhteellisen turvallisesti olettaa uralilaisen ekspansion alkaneen alueelta, jossa kielikunnan syvin diakroninen kuilu sijaitsee, eli kielikunnan varhaisimman murteutumisen alueelta. Tästä tutkijat ovat olleet yksimielisiä; erimielisyyttä on ollut vain tuon kohdan sijoittamisesta: kannatusta ovat saaneet sekä Volgan mutka (Salminen 1999) että Länsi-Siperia (Janhunen 2000).

Olen äskettäin tarkastellut varhaisinta kantauralin jälkeistä murrerajaa ja esittänyt, että 1) murreraja voidaan paikantaa äännetason avulla luotettavammin ja yksiselitteisemmin kuin sanaston avulla; 2) aikaisemmin suomalais-ugrilaisen väli- 
kantakielen tueksi esitetyt äänteelliset uudennokset näyttävät olevan kestämättömiä; 3) samojedi näyttää osallistuneen useisiin sellaisiin äänteenmuutoksiin, joita aikaisemmin on pidetty vain ugrilaisina. Tältä pohjalta näyttääkin siltä, että kantaurali ei olisikaan ensin jakautunut suomalais-ugrilaiseen kantakieleen ja kantasamojediin. Koska otin työssäni perusteelliseen käsittelyyn vain kolme läntisintä (saame, itämerensuomi ja mordva) ja kolme itäisintä kielihaaraa (mansi, hanti ja samojedi), jää keskisten kielihaarojen tarkka taksonominen asema tulevien tutkimusten selvitettäväksi. Kuitenkin kolmea läntisintä kielihaaraa yhtäällä ja neljää itäisintä kielihaaraa toisaalla (unkari mukaan lukien) näyttävät yhdistävän eräät äänteelliset uudennokset, joten kielikunnan ääripäät näyttävät muodostaneen yhtenäiset murteensa, vastaavasti länsiuralilaisen ja itäuralilaisen murteen. Näiden reunimmaisten kantamurteiden ulkopuolelle jäävät kielihaarat mari ja permi puolestaan joko polveutuvat yhteisestä keskiuralilaisesta murteesta tai sitten ne ovat eriytyneet esimariksi ja esipermiksi suoraan kantauralista. (Ks. tarkastelun alku; J. Häkkinen 2007.)

Nähdäkseni varhaisin uralilainen murreraja sijoittuukin suhteellisen suppealle vyöhykkeelle, itäisimmillään permin ja ugrilaisten kielten väliin (erottaen itäuralilaisen murteen muista) ja läntisimmillään marin ja mordvan väliin (erottaen länsiuralilaisen murteen muista). Vaikka pidänkin alustavasti ensimmäistä vaihtoehtoa todennäköisempänä, ei toistakaan voida suoralta kädeltä hylätä tässä vaiheessa tutkimusta; syvennyn asiaan tarkemmin tekeillä olevassa väitöskirjassani. Näin ollen maantieteellisesti läntisin mahdollinen varhaisimman murrerajan sijainti on Surajoella, noin $200 \mathrm{~km}$ Volgan mutkan länsipuolella - tämä joki oletetaan mordvalaisten muinaisen asuinalueen itärajaksi (Bartens 1999: 13). Itäisin mahdollinen sijainti taas on Kamajoella Kaman ja Belajan yhtymäkohdassa, noin 300 km Volgan mutkan itäpuolella; tätä idempänä ei permiläisiä kieliä tiedetä vanhastaan puhutun, vaan ne ovat vasta myöhemmin levinneet pohjoiseen ja itään syrjäyttäen ugrilaisia kieliä (Kannisto 1927).

Kantauralin puhuma-alueen laajin mahdollinen ulottuvuus voidaan näin kielikunnan taksonomian perusteella rajata Uralvuoriston länsipuolelle, Volgan mutkan eli Volgan ja Kaman yhtymäkohdan ympäristöön karkeasti noin 300 kilometrin säteellä. Tämä ympyränmuotoinen alue on pinta-alaltaan noin $280000 \mathrm{~km}^{2}$ eli hieman suurempi kuin nykyinen Romania, joten sen alueelle on mahtunut useitakin puhumaalueita, kun otetaan huomioon pyyntiyhteisöjen pienet puhujamäärät (ks. Janhunen 2005: 84; Aikio 2006b: 49). Seuraavissa luvuissa etsitään tarkennusta tähän alueeseen tarkoituksena paikantaa kantauralin alkuperäinen ekspansiokeskus. Tarkastelun tulokset tästä luvusta alkaen on merkitty kirjoituksen liitteenä olevaan karttaan.

\subsection{Kantauralilaiset puiden nimitykset}

Koska "vanhanaikainen" paleolingvistinen analyysi puidennimityksineen on viime vuosikymmeninä ollut jossain määrin väheksytyssä asemassa, on syytä korostaa, että analyysin on täytettävä tiukat kriteerit: merkityksen ja äänneasujen on oltava riittävän säännöllisiä. Ansaittua kritiikkiä on kohdistettu sellaiseen paleolingvistiseen tutkimukseen, jossa sanan alkuperäisen merkityksen rekonstruoiminen tai tarkoitteen levinneisyyden selvittäminen on epävarmaa (Salminen 2001: 391). 
Puiden muinaisen levinneisyyden kartoittaminen on paljon varmemmalla pohjalla kuin esim. eläinten levinneisyyden selvittäminen, mutta kovinkaan varmaa yhtäläisyyttä ei puiden levinneisyysalueen ja kielialueen välille kuitenkaan voida vetää. Tarkasteltavana ajanjaksona lehtipuiden maksimaalinen levinneisyysalue oli viilenneen ilmaston vuoksi jo supistunut pohjoisen lisäksi myös idän suunnalla (Carpelan \& Parpola 2001: 117-119), mutta varsinaisen levinneisyysalueen ulkopuolellekin on suotuisille alueille jäänyt esiintymäsaarekkeita. Onkin vaikea päätellä, milloin tällaisia saarekkeita on niin runsaasti, että puulla on ollut riittävä merkitys oman nimityksen saamiseksi, ja onko tarvetta tarkalle eronteolle yleensä ollut. Harvan nykysuomalaisenkaan on tarpeen erottaa raitaa, halavaa ja salavaa toisistaan, vaan niihin kaikkiin voidaan viitata nimityksellä paju. Tällä perusteella voitaisiin ajatella, että hyvin vähäisinä määrinä suppeilla alueilla esiintyvillä puulajeilla ei välttämättä olisi ollut kielessä omaa nimitystä, ainakaan laajemmin tunnettua. Toisaalta tiedetään tapauksia, että kielessä on ollut nimitys puulle, jota ei lainkaan kasva puhuma-alueella (Kaisa Häkkinen, henkilökohtainen tiedonanto).

Oman ongelmansa aiheuttaa se, että siitepölymäärät eivät suoraan vastaa puulajien määräsuhdetta: joillain lajeilla siitepöly on suhteellisesti vähäisempää tai ei esimerkiksi leviä yhtä laajalle alueelle kuin toisilla lajeilla (Heikki Simola, henkilökohtainen tiedonanto). Näin on selvää, että kun jo siitepölytietojen muuttaminen puiden esiintymätiedoksi sisältää melkoisen virhemarginaalin, niin tämän esiintymätiedon pohjalta tehtävissä puiden nimiä koskevissa päätelmissä epävarmuus kertautuu.

Toisaalta havupuut eivät ole siinä määrin alttiita ilmaston vaihteluille kuin jalot lehtipuut, vaan niiden (kuusi, sembramänty, siperianpihta, lehtikuusi) esiintymisalue on hitaasti levittäytynyt idästä länteen. Näiden puiden nimitysten kohdalla voitaneen olettaa, että puunnimitys edellyttää kyseistä puuta kasvaneen ainakin puhuma-alueen lähistöllä, todennäköisesti myös itse puhuma-alueella.

Useimmat puut, joiden nimityksillä on kielikunnassa laaja levikki, esiintyvät laajalla alueella Euraasian havu- ja lehtimetsävyöhykkeillä: kuusi, koivu, tuomi, paju ja mänty. Näiden puiden nimityksistä - niin vanhoja kuin ne saattavat ollakin - ei siis ole apua alkuperäisen puhuma-alueen paikantamisessa. Kantakielen puhuma-alueen kannalta on kuitenkin muutama merkittävä alkuperältään itäinen havupuulaji, joiden levikki taigavyöhykkeellä on suppeampi. Seuraava paleolingvistinen katsaus perustuu Y. H. Toivosen ja Péter Hajdún tutkimuksiin (Toivonen 1953; Hajdú 1975).

Kantauraliin voidaan palauttaa säännöllisesti sana *seksi > udmurtti susi-pu komi sus-pu $\sim$ mansi *tiit $\sim$ hanti $*_{L}$ LiijeL $\sim$ samojedi *titâ(jần). Sana on säännöllinen, se on mm. osallistunut itäuralilaiseen muutokseen $*_{S}>*_{S}>*_{L}$. Itäuralin ulkopuolella sanaa tavataan vain permissä, mutta sibilanttiedustuksen perusteella sana ei voi olla permissä itäuralilainen laina, vaan sen on periydyttävä jo kantauralista.

Sanan merkitys on kaikissa kielissä 'sembramänty (Pinus cembra)' lukuun ottamatta udmurttia, jossa se on 'kataja'. Tämä siirtymä on ymmärrettävä, koska udmurttia ei puhuta sembramännyn levinneisyysalueella: sembramännyn levinneisyys ulottuu Euroopan puolelle vain kapean kaistaleen verran Kaman yläjuoksun ja Uralvuoriston välillä, ja tänne sembramänty on levinnyt idän suunnasta (Hajdú 1975: 39). 
Kantauraliin voidaan palauttaa myös sana *ńulka (rekonstruktio perustuu mariin, permiin ja samojediin; mansin ja hantin vokaalisto on epäsäännöllinen) > mari nulgo

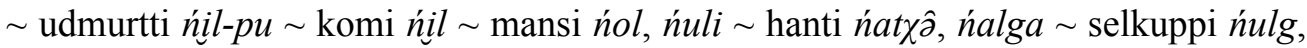
ńolg $\sim$ kamassi nelga. Juha Janhunen on rekonstruoinut kantasamojediin asun *ńulkå (Janhunen 1977: 112), joka on sikäli epäodotuksenmukainen, että säännöllisesti kantauralin $* u$ - $a>$ kantasamojedin $* \hat{\jmath}$-å. Koska myös tavunloppuisen lateraalin säilyminen samojedissa on epäodotuksenmukaista, sana voisikin olla laina esihantista kantasamojediin (Juha Janhunen, henkilökohtainen tiedonanto). Soveltamani levikkikriteerin perusteella kuitenkin jo sanan esiintyminen hantissa ja mansissa riittää osoittamaan sanan kantauralilaiseksi. Mansin sana voisi *k:n epäodotuksenmukaisen kadon vuoksi teoriassa olla lainaa esipermistä, mutta hantin sanaa lienee pidettävä kantakielen perintönä - etenkin jos sana on siitä lainattu samojediinkin.

Sanan merkitys on kaikkialla 'siperianpihta (Abies sibirica)', vaikka eri sanakirjoissa tavataankin käännöksiä 'jalokuusi', 'valkokuusi' tai jopa 'hopeakuusi', jotka kaikki kuitenkin viittaavat Euraasiassa pihtaan eli jalokuuseen - varsinaiset nimillä valkokuusi ja hopeakuusi tunnetut puut ovat nimittäin pohjoisamerikkalaisia lajeja. Siperianpihdan levinneisyys ulottuu Euroopan puolella vain Kamajoelle ja Petšoran yläjuoksulle (Hajdú 1975: 39).

Sembramännyn ja pihdan nimitysten perusteella voin vain toistaa Péter Hajdún kannan, johon Mikko Korhonenkin yhtyi: kantauralin (tai esiuralin; ks. jäljempänä) puhuma-alue ei voi olla kovinkaan läntinen, koska Euroopan puolella kyseiset puut kasvavat vain kapealla kaistaleella Keski- ja Pohjois-Uralin sekä Kaman ja Petšoran yläjuoksujen tienoilla (Hajdú 1975: 40; Korhonen 1984: 63). Hajdú käsitteli myös lehtikuusen nimitystä, mutta suppean levikin ja äänteellisesti epäsäännöllisen edustuksen vuoksi olen jättänyt sen pois.

Lisäksi Hajdú oletti, ettei suomalais-ugrilainen kantakieli ole voinut hajota ennen kuin jalavan levinneisyysalue saavutti käsiteltyjen siperialaisperäisten havupuiden levinneisyysalueen, koska nimitys 'jalava (Ulmus)' voidaan palauttaa suomalais-ugrilaiseen kantakieleen. Marin, unkarin ja itämerensuomen (jossa sanan merkitys on 'salava (Salix fragilis)') perusteella voitaisiin kantauralin asuksi rekonstruoida *séli(ya) (itämerensuomen toisen tavun $a$ olisi sekundaari), kun taas mordvan sanan vokaalisto on epäsäännöllinen. Jälkiä kolmannen tavun konsonantista voidaan nähdä itämerensuomessa ja mordvassa, mitä on vaikea selittää, jos itämerensuomen sana oletetaan germaaniseksi lainaksi - salavaa on jo kauan verrattu samannäköisiin germaanisiin sanoihin (SSA s.v. salava).

Nyt kun ei nähdäkseni ole perusteltua erottaa toisistaan uralilaista ja suomalaisugrilaista kielentasoa, olisi tämäkin sana palautettava jo kantauraliin. Hajdún mukaan lännestä levinnyt jalava kohtasi siperialaisperäiset havupuut jo kuudennella vuosituhannella eaa. (Hajdú 1975: 41), ja kivikauden loppuun tultaessa jalavaa on tavattu jo laajalta alueelta 62. leveyspiirin eteläpuolelta. Tässä suhteessa jalava ei ole erityisen merkityksellinen kantauralin puhuma-alueen paikannuksen kannalta, ottaen huomioon edellä esitetyn myöhäisen ajoituksen.

Petri Kallio on äskettäin osoittanut erään ongelman paikannettaessa puhumaaluetta puidennimien avulla: kantauraliin on voitu palauttaa vain sanoja, joilla on 
vastine samojedissa. Ja koska kantasamojedia on puhuttu hyvin idässä, kantauraliin palautettavat puidennimitykset painottuvat niin ikään itäisiksi (Kallio 2006: 5). Katson kuitenkin osoittaneeni, että kantauralin varhaisin murreraja osuu todennäköisimmin suomalais-permiläisten ja ugrilais-samojedilaisten kielten väliin (J. Häkkinen 2007). Siksi itäisestä painopisteestä ei uskoakseni ole enää pelkoa: tavataanhan edellä käsiteltyjä taigavyöhykkeen puidennimityksiäkin lännessä permissä ja marissa saakka. Vastaavasti läntisten jalojen lehtipuiden nimitykset näyttäisivät olevan vasta myöhään lehtimetsävyöhykkeellä omaksuttuja (ks. seuraava luku). Yhdessä siis itäisten puulajien nimitysten vanhuus ja läntisten puulajien nimitysten nuoruus todistavat, että kantauralin alkuperäinen puhuma-alue on ollut melko itäinen.

Vielä on korostettava sitä seikkaa, ettei esi- tai kantauraliin ole voitu omaksua sembramännyn ja pihdan nimityksiä sellaisella alueella, jolla nämä puut ovat olleet tuntemattomia. Näin ollen on suljettava pois aiemmin hahmotellun alueen koko läntinen puolisko eli Volgan mutkan länsipuoli sekä lisäksi Kaman eteläpuolinen alue. Lisäksi mitä varhaisempaan aikaan mennään, sitä idempänä näiden puiden levinneisyyden länsiraja on kulkenut. Tästä seuraa, että mikäli kantauralin myöhäisvaiheen puhuma-alue halutaan sijoittaa niinkin etelään kuin Kaman alajuoksun ja Volgan mutkan vaiheille (kuten tässä tarkastelussa), jossa sembramäntyä ei ole koskaan esiintynyt (tuolla alueella puhuttavassa udmurtissa sanan merkitys onkin muuttunut), on oletettava puiden nimitykset omaksutun jo esiuraliin. Tällöin tietysti esiuralia on oletettava puhutun jossakin näiden puiden levinneisyysalueella eli kantauralin puhumaalueen koillispuolella Kaman yläjuoksulla, tai sitten peräti Uralin takana Siperiassa. Missään lännempänä näihin puihin ei ole voitu tutustua. Tämä seikka sulkee pois kaikki sellaiset oletukset, joiden mukaan esiuralilaista kehitystä olisi etsittävä lännestä, Ylä-Volgan suunnalta.

\subsection{Lehtimetsävyöhykkeen puiden nimitykset}

Arkeologisin perustein kantauralin leviämiskeskus on haluttu sijoittaa juuri lehtimetsävyöhykkeelle pääosin Ylä-Volgan eteläpuolelle (esim. Carpelan \& Parpola 2001: 79). Kielellisin perustein lehtimetsävyöhyke ei kuitenkaan tule kysymykseen vanhimpana uralilaisena puhuma-alueena; jo edellä käsitellyt havupuiden nimitykset todistavat tämän, ja lisäperustelut voidaan esittää seuraavana argumenttiketjuna:

Ensiksikin itämerensuomi ja mordva ovat ainoat nykyaikaan säilyneet uralilaiset kielihaarat, joiden puhuma-alue on jo varhain siirtynyt Laatokan-Volgan-linjan eteläpuoliselle lehtimetsävyöhykkeelle, kun sen sijaan lähimmät kielihaarat saame ja mari näyttäisivät pysytelleen pitkään tuon linjan pohjoispuolella. Toiseksi lukusana '10' on itämerensuomessa ja mordvassa yhteinen uudennos *kümmen, kun taas saamessa ja marissa on säilynyt vanha uralilainen lukusana *luka' '10'. Kolmanneksi mainitussa uudessa itämerensuomalais-mordvalaisessa lukusanassa on geminaattanasaali ${ }^{*} m m$, joka oli täysin vieras kantauralin ja oletetun suomalais-ugrilaisen kantakielen fonotaksille (ks. Sammallahti 1988: 492). Neljänneksi lehtimetsävyöhykkeen puiden nimet näyttävät niin ikään olevan itämerensuomessa ja mordvassa samanaikaisia uudennoksia, koska sanassa suomi tammi mordva tumo 'tammi (Quercus robur)' on sama epä- 
uralilainen *mm kuin sanassa *kümmen ja koska sanassa suomi va(a)htera $\sim$ mordva ukštor 'vaahtera (Acer platanoides)' on sama epäsäännöllinen vokaalivastaavuus (esiitämerensuomi * $a \sim$ esimordva $*$ o) kuin sanassa tammi (tätä vastaavuutta tavataan jostain syystä myös muutamissa vanhoissa perintösanoissa). Viidenneksi on myös muita lähinnä itämerensuomeen ja mordvaan rajoittuvia sanoja, joissa on epäuralilaisia äännesekvenssejä, nimittäin *šn: suomi vehnä mordva viš 'spelttivehnä (Triticum spelta)' ja *šm: suomi lehmä mordva lišme 'hevonen'. Kuudenneksi viimemainitut sanat kuuluvat kiistatta maatalouselinkeinon piiriin, joka lehtimetsävyöhykkeellä tunnettiin jo kolmannen vuosituhannen lopulla eaa. (esim. Anthony 2001), kun taas havumetsävyöhykkeelle maatalous levisi vasta paljon myöhemmin.

(Eräillä mainituista sanoista on vastine myös marissa ja/tai udmurtissa, mutta nämä lienevät nuorempia lainoja. Ainakin marin sana waštar 'vaahtera' on nuori, koska se on kaikissa päämurteissa $a$ :llinen eikä siten palaudu mihinkään kantamarin vokaaliin. Marin tumo 'tammi' voisi palautua jo kantamarin * $u$ :hun ja edelleen esimarin ${ }^{*}$ : hon, mutta yhtä hyvin se voisi olla nuori laina esimerkiksi mordvan $u$ :llisesta asusta. Marin sanassa wiste 'speltti' suhuton sibilantti viittaa nuoreen lainaan, samoin se, että ensitavun $i$ on kaikissa päämurteissa täysvokaali eikä siksi palaudu mihinkään kantamarin äänteeseen.)

Nämä seikat voidaan nähdäkseni tulkita vain yhdellä uskottavalla tavalla: uralilainen kieli on levinnyt aluksi länteen Volgan pohjoispuolella havumetsävyöhykettä seuraten, ja vasta myöhemmin esimordva ja esi-itämerensuomi (sekä mahdollisesti muut, sittemmin kadonneet uralilaiset kielet) ovat siirtyneet Laatokan-Volgan-linjan eteläpuolelle lehtimetsävyöhykkeelle, missä niihin on omaksuttu paikalliseen luontoon ja maatalouteen liittyviä lainasanoja ja niiden mukana uusia epäuralilaisia äännesekvenssejä alueen alkuperäisistä paleoeurooppalaisista kielistä (tai vehnä-sanan kohdalla mahdollisesti indoeurooppalaisesta kielestä; ks. Koivulehto 2002: 592).

Tähdennettäköön, että esitetyn argumenttiketjun heikoin lenkki on kolmas kohta eli epäuralilainen geminaatta *mm. On nimittäin pidetty mahdollisena, että itämerensuomen *mm olisi sekundaari, koska mordvassa sellaista ei voida todistaa koskaan olleenkaan. Nähdäkseni ratkaisu on kuitenkin melko selvä, kun tarkastellaan itämerensuomalais-mordvalaisia sanavastineita iän mukaan ryhmitellen. Kun katsotaan Pekka Sammallahden sanalistan uralilaisia ja suomalais-ugrilaisia sanoja, niin sellaisia vokaalienvälisen *m:n sisältäviä sanoja, joilla on vastine mordvassa, on 10. Näistä kahdeksassa mordvassa on $m$ (suomi tuomi $\sim$ mordvaE l'om $\mid$ suomi kumo- $\sim$ mordvaE koma $\mid$ suomi nimi $\sim$ mordvaE lem $\mid$ *ńomala $>$ mordvaE numolo 'jänis' $\mid$ suomi oma

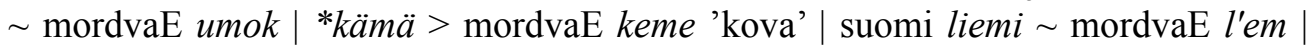
*śoma $>$ mordvaE śumordo- 'huolehtia') ja kahdessa $v$ tai $\eta$ (suomi lumi $\sim$ mordvaE lov/loy | suomi kumuri $\sim$ mordvaE kovol 'pilvi'), joita voidaan pitää heikkenemiskehityksen tuloksena. Levikin perusteella nuoremmissa sanoissa sen sijaan ovat lähes yksinomaisina vastaavuudet kantasuomi $*_{m} \sim$ mordva * $v$ (suomi huumar/huhmar $\sim$ mordvaE šovar, suomi sumu $\sim$ mordvaE sov, suomi loma $\sim$ mordvaE luv) ja kantasuomi *mm $\sim$ mordva *m (suomi kymmen $\sim$ mordvaE kemeń, suomi tammi mordvaE tumo). Poikkeuksena on vain balttilainen lainasana suomi siemen $\sim$ mordvaE śime ja mordvan osalta homonyyminen sanue suomi siema- mordvaE śime- 'juoda'. 
Pääsääntöisesti siis vanhassa sanastossa tavataan vastaavuutta ims. ${ }^{*} m \sim$ mordva $*_{m}$, kun taas levikin perusteella nuoremmassa sanastossa tavataan vastaavuuksia ims. ${ }^{*} m \sim$ mordva $*_{v}$ ja ims. ${ }^{*} m m \sim$ mordva $*_{m}$. Mikään kontekstuaalinen seikka ei näyttäisi selittävän vaihtelevaa edustusta. On kuitenkin kiinnostavaa, että lehtimetsävyöhykkeen oletetut paleoeurooppalaiset lainat kuuluvat nuorempaan kerrostumaan, eli niissä tavataan yksinomaan mordvan $* m$ itämerensuomen *mm:n vastineena. Tämä viittaa siihen, että esimordvalaiset toistivat paleoeurooppalaisen lainanantajakielen kvantitatiivisen eron $\left(*_{m} m\right.$ vs. $\left.{ }^{*} m\right)$ kvalitatiivisena $\left(*_{m}\right.$ vs. $\left.{ }^{*} v\right)$, eli kielessä jo vanhastaan olevilla aineksilla, kun taas esi-itämerensuomalaiset omaksuivat kvantiteettiopposition sellaisenaan $\left({ }^{*} m m\right.$ vs. ${ }^{*} m$ ), eli kieleen ilmestyi aiemmin vieras geminaattanasaali. Esimordvaan ei siis missään vaiheessa olisi syntynyt varsinaista

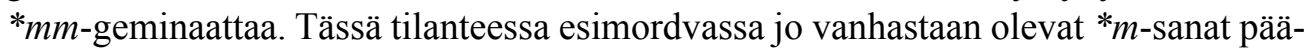
osin säilyivät ennallaan *m-sanoina, vaikka pari niistä näyttääkin sporadisesti heikentyneen uusien sanojen tapaisesti: $*_{m}>*_{\eta}(>v)$. Balttilaislainoja taas voidaan pitää vieläkin myöhäisempinä, koska niiden on ajateltu levinneen erikseen mordvaan ja itämerensuomeen: niiden lainautumisen aikoihin ei esimordvassa enää ollut tarvetta mainitulle eronteolle, koska lainanantajakielessä ei ollut eroa ${ }^{*} m m$ vs. ${ }^{*} m$.

Edellä käsiteltyjen sanojen perusteella näyttääkin siltä, että Volgan eteläpuolinen lehtimetsävyöhyke on paikoin ollut kieleltään paleoeurooppalaista vielä maatalouden levitessä tälle alueelle kolmannen vuosituhannen lopulla eaa., vaikka indoeurooppalaisiakin alueella lienee jo ollut (sikäli kuin alueen nuorakeraamiset kulttuurit voidaan yhdistää indoeurooppalaisiin). Uralilainen kieli olisi siis levinnyt tälle alueelle vasta verraten myöhään.

On kuitenkin muistettava, että lehti- ja havumetsän välisen rajan sijoittaminen juuri Volgalle on enemmän tai vähemmän sopimuskysymys. Nimittäin tarkasteltua ajankohtaa (suunnilleen vuodesta 2000 eaa. eteenpäin) aikaisemmin vallitsi lämpimämpi jakso, jolloin jaloja lehtipuita esiintyi paljon nykyistä pohjoisempana (ks. levinneisyyskartasto Huntley \& Birks 1983), ja esimerkiksi tammi ehti Péter Hajdún mukaan Petšoralle saakka (Hajdú 1975: 41). Tämä lämpöjakso kulminoitui noin 4000 eaa., minkä jälkeen pohjoisen Euroopan ilmasto viileni selvästi pronssikautta kohti, mutta viilentymisen lisäksi jalojen lehtipuiden osuutta pienensi idästä levinnyt kuusi, joka valloitti juuri niitä runsasravinteisimpia alueita, joilla jalot lehtipuut olivat viihtyneet (Vuorela 2002: 84). Silti pronssikaudella, kun uralilaiset levittäytyivät kohti länttä, Volgan pohjoispuolellakin on epäilemättä ollut jalojen lehtipuiden esiintymiä, mutta niiden todellisen osuuden selvittäminen on vaikeaa (ks. edellinen luku).

Pohjois-etelä-suunnan lisäksi on kuitenkin otettava huomioon myös länsi-itäsuunta: jalot lehtipuuthan ovat levittäytyneet itäisimpään Eurooppaan lännestä. Myös tähän suuntaan ilmaston vaihtelut ovat jossain määrin vaikuttaneet: esimerkiksi lehmusta on aiemmin kasvanut myös Siperian puolella, ja tammen levinneisyys ulottuu Uralvuoristoon saakka (Carpelan \& Parpola 2001: 117-119). Jos jalojen lehtipuiden ajallisesta esiintymisestä halutaan etsiä jotain laadullista eroa, niin voidaan sanoa, että kantauralin hajoamisen aikatasossa jalojen lehtipuiden päälevinneisyysalue ulottui Volgan itäpuolelle aina Uralvuoristoon saakka, kun taas Volgan pohjoispuolelle se oli ulottunut aikaisemmalla lämpökaudella. Vaikka siis Volgan pohjoispuolellakin yhä 
esiintyi saarekkeisesti jaloja lehtipuita, ne eivät olleet läheskään samassa mittakaavassa läsnä kuin Volgan-linjan eteläpuolella.

Kun pohditaan, missä jalojen lehtipuiden nimitykset olisivat voineet lainautua esi-itämerensuomeen ja esimordvaan (ja niistä tai muista kielistä edelleen mariin ja permiin), niin selvästi todennäköisemmin tämä on tapahtunut Volgan-linjan eteläkuin pohjoispuolella. Olisi nimittäin uskottavaa olettaa sanan tammi (kuten myös vaahtera sekä alueelliselta ja kielelliseltä levikiltään vastaava pähkinä) lainautuneen samaan aikaan kuin esi-itämerensuomeen ja esimordvaan lainattiin sanat kymmen, lehmä ja vehnä. Koska saame ja mari ovat mainitun lukusanan suhteen vanhalla kannalla ja koska niiden puhuma-alueet ovat vanhastaan rajoittuneet Laatokan-Volganlinjan pohjoispuolelle, muodostuu Volga rajaksi, jonka pohjoispuolelle ei lainattu uutta lukusanaa. Raja näyttäisi olleen tässä vaiheessa sekä kieli- että elinkeinoraja (sen eteläpuolella tunnettiin jo varhain maatalous), joten se sopisi hyvin myös jalojen lehtipuiden nimitysten vanhimman lainautumisen alkuperäiseksi rajaksi, vaikkei se aivan tarkasti vastaisikaan jalojen lehtipuiden levinneisyyden todellista pohjoisrajaa.

Voitaneen pitää merkittävänä sitä seikkaa, että kantauralissa ei ollut nimityksiä tammelle eikä vaahteralle, joiden päälevinneisyysalue tuohon aikaan rajoittui pääosin Volgan-linjan eteläpuolelle, mutta sen sijaan oli nimitys jalavalle, jonka levinneisyys ulottui pohjoisessa 62. leveyspiirille. Kun lisäksi läntisiin kielihaaroihin lainattiin nämä nimitykset muiden paleoeurooppalaisten lainasanojen perusteella vasta Volganlinjan eteläpuolella, voidaan aiemmin hahmotellusta Volgan mutkan ympärille piirretystä kantakielen oletetusta puhuma-alueesta sulkea pois ympyrän koko eteläinen puolisko.

\subsection{Indoeurooppalaisten ja arjalaisten lainasanojen todistus}

Koska kantauraliin on omaksuttu myöhäiskanta-arjalaisia lainasanoja (ks. tarkastelun alkupuoli), on paikannettava uralilais-arjalainen kontaktialue. Uralilaisia kieliä on "aina" puhuttu havumetsävyöhykkeellä ja indoeurooppalaisia kieliä alun perin arovyöhykkeellä. Nämä kaksi vyöhykettä lähestyvät toisiaan Euroopan itäisimmällä alueella Volgan ja Uralvuoriston välillä. Havumetsävyöhykkeen eteläraja ulottuu Kaman alajuoksulle, arovyöhykkeen pohjoisraja Samarajoelle, ja ns. metsäaro lähestyy Kamaa.

Esiarjalaisena pidetty Poltavkan kulttuuri (2750-2000 eaa.) ulottui pohjoisessa Samarajoelle saakka (Carpelan \& Parpola 2001: 68-69), ja kanta-arjalaisena pidetty Abaševon kulttuuri saavutti vuoden 2200 eaa. tienoilla Volgan-Kaman-linjan, ulottuen paikoin jopa hieman sen pohjoispuolelle (Carpelan \& Parpola 2001: 94-95). Voidaan siis olettaa, että kanta-arjalaisten ja kantauralilaisten kontaktipinta kolmannen vuosituhannen lopulla eaa. oli Kamajoella. Myös esiarjasta kantauraliin lainatut sanat *mekši 'mehiläinen (Apis mellifera)' ja *meti 'hunaja' viittaavat kontaktialueen varhaiseen sijaintiin juuri Keski-Volgan tienoilla (Carpelan \& Parpola 2001: 117), joten tämä on luontevin alue myös myöhäisemmille arjalaiskontakteille. 
Tässä kohtaa on kuitenkin huomioitava myös muut indoeurooppalaiset lainasanakerrostumat. Melko vakiintuneen käsityksen mukaan varhaisimmat lainasanat olisi omaksuttu jo kantaindoeuroopasta kantauraliin. Kun nyt kuitenkin kantaurali näyttää olevan jopa puolitoista vuosituhatta kantaindoeurooppaa nuorempi kielentaso, on syytä arvioida tilanne uudelleen. Olen äskettäin esittänyt, että jo kantauralissa olisi havaittavissa kaksi eri-ikäistä arkaaista indoeurooppalaista lainasanakerrostumaa: vanhemmassa kerrostumassa indoeurooppalainen laryngaali olisi vokaalien välissä substituoitu varhaiskantauralin *x:11ä, nuoremmassa taas myöhäiskantauralin $*_{s ̌}$ :1lä. Aikaisemminhan on oletettu, että $* \check{s}$-kerrostuma olisi vasta kantauralia nuorempi (esim. Koivulehto 1991). Kun kuitenkin $*_{s}$ :ää tavataan laryngaalin substituuttina myös sanoissa, joiden levikki ulottuu itäuralilaisen (ugrilais-samojedilaisen) murteen jatkajiin, voidaan nähdäkseni olettaa $* x$-sanat varhaiskantauraliin omaksutuiksi ja $*_{S}$ sanat myöhäiskantauralilaisiksi. (J. Häkkinen 2007: 42-44.)

Tämä on hyvin sopusoinnussa sen kanssa, että vanhimmatkin kantauralin indoeurooppalaiset lainasanat ovat peräisin myöhäiskantaindoeuroopasta (Kallio 2006: 10). Lisäksi kantauralin esiarjalaisissa lainasanoissa tavataan niin ikään *x:ää (esim. Koivulehto 1999a: 216), kun taas kanta-arjalaisissa lainasanoissa sitä ei enää tavata. Voitaneenkin olettaa, että esiarjalainen lainasanakerrostuma olisi lainattu samaan aikaan kuin vanhempi arkaainen indoeurooppalainen lainasanakerrostuma sellaiseen varhaiskantauralilaiseen kielentasoon, jossa oli vielä *x $(\approx$ soinniton velaarispirantti $\chi)$. Sen sijaan kanta-arjalainen lainasanakerrostuma olisi lainattu samaan aikaan kuin myöhempi arkaainen indoeurooppalainen lainasanakerrostuma sellaiseen myöhäiskantauralilaiseen kielentasoon, jossa $* x$ oli jo soinnillistunut $*_{\gamma}:$ ksi. Tämä $*_{\gamma}$ ei ollut enää riittävän hälyinen indoeurooppalaisten laryngaalien substituutiksi, joten ne olisi tässä vaiheessa korvattu hälyisemmällä *šlllä.

Tällainen suhteellinen kronologia on perusteltu myös siksi, että viimeiset arkaaiset indoeurooppalaiset lainasanat näyttävät sekä äänneseikkojen että levikin perusteella lainatun vasta kanta-arjalaisten lainasanojen jälkeen; on siis oletettava luoteisindoeurooppalaisen murteen säilyneen arkaaisena hyvin myöhäiseen aikaan, ehkä jopa toiselle vuosituhannelle eaa. (Kallio 2006: 11; Mallory 2001: 353). Tämä selittää myös sen, miksi eräillä arkaaisilla indoeurooppalaislainoilla on hyvin suppea ja läntinen levikki: niitä on omaksuttu vielä pronssikaudella läntisimmille uralilaisille kielialueille.

Näin siis aiemmin kantaindoeurooppalaisina pidetyt lainasanat eivät edellisen perusteella olisikaan kantaindoeurooppalaisia vaan nuorempia. Koska esiarja oli kantaindoeuroopan tytärkieli, ei samanaikaista indoeurooppalaista kielimuotoa voida kutsua enää kantaindoeuroopaksi, vaikka tämä äänteellisin kriteerein näyttäisikin säilyneen kantaindoeuroopan tasolla. Käytänkin tuosta kielentasosta nimitystä arkaainen indoeurooppa (tai luoteisindoeurooppa). Virhemarginaalit muistaen voidaan lainasanakerrostumien kronologia olettaa suunnilleen seuraavanlaiseksi: 


\begin{tabular}{|c|c|c|}
\hline Aika eaa. & \multicolumn{2}{|l|}{ Kielentaso } \\
\hline $\begin{array}{l}\text { Vaihe I } \\
\text { n. } 3500\end{array}$ & \multicolumn{2}{|c|}{$\begin{array}{l}\text { Myöhäiskantaindoeurooppa hajoaa, ei välttämättä vielä lainasanoja } \\
\text { esiuraliin }\end{array}$} \\
\hline $\begin{array}{l}\text { Vaihe II } \\
\text { n. } 2800-\end{array}$ & $\begin{array}{l}\text { Vanhat arkaaiset indoeurooppalaiset } \\
\text { lainasanat varhaiskantauraliin: } \\
\mathrm{IE}_{1} * d o h_{3^{-}}>\text {vk-U *toxi- 'tuoda' }\end{array}$ & $\begin{array}{l}\text { Esiarjalaiset lainasanat } \\
\text { varhaiskantauraliin: } \\
\text { esi-A * }{ }^{\prime} u g^{h} e w->\text { vk-U } \\
\text { *jôwxi- (*juxi-) 'juoda' }\end{array}$ \\
\hline $\begin{array}{l}\text { Vaihe III } \\
\text { n. } 2300-\end{array}$ & $\begin{array}{l}\text { Nuoret arkaaiset indoeurooppalaiset } \\
\text { lainasanat myöhäiskantauraliin: } \\
\mathrm{IE}_{2} * b^{h} e h_{1}-(\text { ye/o- })>\mathrm{mk}-\mathrm{U} * \text { *ěsa- 'keittääa' }\end{array}$ & $\begin{array}{l}\text { Kanta-arjalaiset } \\
\text { lainasanat myöhäis- } \\
\text { kantauraliin } \\
\text { (uralissa ei } *_{x}: \text { ää) }\end{array}$ \\
\hline $\begin{array}{l}\text { Vaihe IV } \\
\text { n. 1800- }\end{array}$ & $\begin{array}{l}\text { Suppealevikkiset arkaaiset indo- } \\
\text { eurooppalaiset lainasanat kantauralin } \\
\text { länsimurteisiin }\end{array}$ & $\begin{array}{l}\text { Kantairanilaiset laina- } \\
\text { sanat kantauralin } \\
\text { murteisiin (tai jopa } \\
\text { myöhäiskantauraliin, } \\
\text { vrt. 3.3) }\end{array}$ \\
\hline
\end{tabular}

Taulukko I. Varhaisimpien indoeurooppalaisten lainasanakerrostumien kronologia. Aikaisemmin oletettiin vanhimpien II-vaiheen kerrostumien tulleen kantauraliin, III-kerrostuman suomalais-ugrilaiseen kantakieleen ja IV-kerrostuman uralilaisiin tytärkieliin. Nyt kun kantaurali näyttää hajonneen vasta vaiheiden III ja IV välissä, siirtyvät vanhemmat kerrostumat (II: vanhimmat indoeurooppalaiset ja esiarjalaiset lainasanat) automaattisesti myöhäiskantauralia edeltäville tasoille.

Kantauralin paikannuksen kannalta tärkeää on nyt etsiä alue, jossa jo varhaiskantauralista lähtien (ehkä kolmannen vuosituhannen eaa. alkupuolelta) on ollut kontakteja kahteen eri indoeurooppalaiseen kielimuotoon. Esiarjalaisen kehityksen oletetaan alkaneen Poltavkan kulttuurissa vuoden 2800 eaa. jälkeen, ja viimeiset kanta-arjalaiset muutokset lienevät tapahtuneet suunnilleen kolmannen vuosituhannen eaa. loppuun tultaessa. Arjalaisena pidetty Abaševon kulttuuri levisi pohjoisessa Volgan-Kamanlinjalle ja paikoin jopa sen pohjoispuolelle. Arkaaista luoteisindoeurooppalaista murretta puolestaan oletetaan puhutun nuorakeraamisen kulttuurin piirissä, joka vuoden 2800 eaa. tienoilla levisi Baltiasta itään Ylä-Volgalle (Fatjanovon kulttuuri) ja vuoteen 2200 eaa. mennessä Kaman suulle saakka (Balanovon kulttuuri). (Carpelan \& Parpola 2001: 85-87.)

Volgan-Kaman-linjan eteläpuolelle kantauralia olisi vaikea sijoittaa, siinä määrin voimakasta mainittujen indoeurooppalaisina pidettyjen kulttuurien vaikutus alueella on ollut, eivätkä tällaista paikannusta tue muutkaan edellä käsitellyt seikat. Balanovon nuorakeraaminen kulttuuri puolestaan ulottui Volgan-linjan pohjoispuolellekin (idässä Volgan mutkaan saakka), joten ainoa varmasti ei-indoeurooppalainen alue tuohon aikaan oli Kamajoen alue. Aiemmin hahmotellusta ympyränmuotoisesta alueesta voidaankin sulkea tällä perusteella pois kaikki muut alueet paitsi koillinen neljännes.

Jorma Koivulehto on painottanut, että arkaaiset luoteisindoeurooppalaiset lainasanat olisi omaksuttu Itämeren piirissä, koska näiden sanojen originaaleja tavataan 
lähinnä germaanista ja baltoslaavista (Koivulehto 2006: 161). Kuitenkin Volgan nuorakeraaminen Fatjanovon kulttuuri on peräisin Itämeren suunnalta (Carpelan \& Parpola 2001: 85), joten sen piirissä puhutussa luoteisindoeurooppalaisessa murteessa on epäilemättä ollut sama sanasto kuin lännempänäkin. Lisäksi baltoslaavilaiset kielet voitaisiin ehkä johtaakin Fatjanovon piiristä: niitähän ei oikeastaan ole mitään syytä olettaa puhutun Itämeren rannoilla kovinkaan varhain. Tähän viittaisi ensiksikin se, että baltin ja germaanin välillä on kulkenut paljon vähemmän lainasanoja kuin itämerensuomen tai saamen ja germaanin välillä (Koivulehto 2002: 591-593). Tämä olisi kummallista, mikäli balttia olisi jo nuorakeraamisesta kaudesta lähtien puhuttu germaanin itänaapurina.

Itämerensuomella (ja saamella) on ollut kontakteja sekä balttiin että germaaniin mutta näillä ei samassa mitassa toisiinsa, mikä viittaa siihen, että nykyisen kolmiomuodostelman sijasta kielet olisivat varhemmin sijoittuneet nauhamaisesti, jolloin itämerensuomi olisi jäänyt jotakuinkin baltin ja germaanin väliin. Itämeren itärannalla olisi hyvinkin voitu puhua joitain tuntemattomia kieliä vielä verraten myöhäisiin aikoihin.

Toiseksi baltoslaavia yhdistää arjalaiseen haaraan (samoin kuin albaniaan ja armeniaan) satemisaatio, jota pidetään alueellisesti levinneenä piirteenä, joten baltoslaavia on luontevinta olettaa puhutun jossakin Keski-Venäjällä satemisaation ulottuvilla. Myös Ylä-Volgan seudulle ulottuvat balttilaisperäiset paikannimet olisi taloudellisinta selittää balttilaisen kielialueen siirtymisellä idästä länteen (uralilaisen kielen seuraamana tai sysäämänä), mikäli tämä vain kielentasoon nähden olisi ajallisesti mahdollista.

\subsection{Yhteenveto paikannuksesta}

Edellä on hahmoteltu kantauralin puhuma-alueen sijainneen sisämaassa, jossakin Itämeren ja Jenisein välisellä jokien halkomalla alankoseudulla havumetsävyöhykkeen eteläosassa. Varhaisimman murrerajan perusteella kantauralin alkuperäinen puhumaalue voidaan rajata alueelle, joka kattaa karkeasti $300 \mathrm{~km}$ Volgan mutkasta joka suuntaan. Sembramännyn ja pihdan nimitysten perusteella on rajattava ulkopuolelle Volgan mutkan länsi- ja eteläpuolelle jäävät kolme neljännestä, paleoeurooppalaisista kielistä lainattujen jalojen lehtipuiden nimitysten vuoksi tästä alueesta on rajattava pois Volgan mutkan eteläpuolelle jäävä puolikas ja indoeurooppalaisten lainasanojen perusteella on rajattava ulkopuolelle Volgan mutkan länsi- ja eteläpuolelle jäävät kolme neljännestä. Jäljelle jää vain yksi alue, jota mikään edellä käsitelty seikka ei sulje pois: koillisin neljännes eli Kamajoen alue (ks. liitekartta). Tämä alue on sopiva myös ajoituksen kannalta tärkeiden kantauraliin palautettavien metallisanojen osalta. Sen sijaan ajoituksen kohdalla käsitelty maanviljelysanasto sopisi ehkä paremmin Kaman eteläpuoliseen alueeseen - niinkin pohjoisessa kuin Kamalla se edellyttäisi tällä tietoa vieläkin myöhäisemmän ajoituksen ja sopisi siksi kyllä hyvin yhteen kantauralin iranilaisten lainasanojen kanssa. Yksin näillä perusteilla ei kuitenkaan voida vetää kantauralia enää etelämmäksi tai myöhäisemmäksi. 
Käsiteltyjen seikkojen kumuloituvan todistuksen perusteella kantauralin alkuperäinen puhuma-alue on sijoitettava karkeasti Kamajoen vesistöalueelle. Todistukset eivät kuitenkaan ole kronologisesti yhtä pakottavia: myöhäiskanta-arjalaiset lainasanat lienee omaksuttu aivan yhtenäisen myöhäiskantauralin lopussa, kun taas sembramännyn ja pihdan nimitykset on voitu omaksua jo paljon aiemmin esiuraliin jossain koillisen tai idän suunnalla. Tällä perusteella olisi teoriassa mahdollista olettaa, että esiuralia olisi aikanaan puhuttu Kaman yläjuoksun ja Uralvuoriston välillä tai jopa Siperian puolella, josta puhuma-alue sitten olisi levinnyt tai siirtynyt Kamaa seuraten etelään, jossa taas vasta olisivat alkaneet kontaktit arjalaisiin ja arkaaisen (luoteis)indoeuroopan puhujiin. Ja koska kantauraliin ei ole tiettävästi omaksuttu lainkaan lainoja varhaiskantaindoeuroopasta eikä edellä esitetyn kronologian perusteella ole välttämätöntä olettaa kantauraliin vielä edes varsinaisia myöhäiskantaindoeurooppalaisia lainasanoja, voidaan hyvin olettaa näiden kielikuntien päätyneen toistensa läheisyyteen vasta myöhäiskantaindoeuroopan jo hajottua eli joskus vuoden 3000 eaa. tienoilla.

Myös typologiselta kannalta kantaurali ja kantaindoeurooppa näyttävät olleen monessa suhteessa niin erilaisia kieliä, ettei niiden sijoittuminen toistensa naapuruuteen voine edustaa alkuperäistä tilannetta: niiden kehittyminen kantakielitasolle ei siis olisi tapahtunut lähekkäisillä alueilla (Janhunen 2001: 208-211). Juha Janhunen onkin äskettäin esittänyt lisäperusteluja sille oletukselle, että kantauralin esivaiheet olisi sijoitettava altailaisen typologian yhteyteen.

Kielen tasoista typologinen jatkuvuus näyttäisi Janhusen mukaan olevan ajallisesti pysyvämpi taso kuin geneettinen jatkuvuus. Jollekin alueelle saattaa levitä uutta geneettistä linjaa edustava kieli, mutta alueella aikaisemmin vallinnut typologia saattaa "tihkua" uuteen kieleen joko substraattina alueen aikaisemmista kielistä tai adstraattina uusista naapurikielistä (tai sekä että). Toisaalta kieleen tällaisen areaalisen interferenssin vaikutuksesta tarttunut typologia leviää kielen mukana uusille alueille siinä missä kielen geneettinenkin linja. Näin esimerkiksi uralilaisen kielen leviäminen Suomeen ja Baltiaan on tuonut alueelle geneettisen identiteettinsä (uralilainen) lisäksi myös typologisen identiteettinsä (ural-altailainen). Janhunen painottaa, että typologiallakin on leviämiskeskuksensa eli "alkukotinsa" ja että laajalla alueella yhtenäinen typologia on palautettava yhteiseen leviämiskeskukseen. (Janhunen 2007.)

Tällä perusteella esiuralia voitaisiin olettaa aikaisemmin puhutun Aasiassa, ehkä pikemminkin Siperian eteläpuolella (jonne altailaisten kielikuntien "alkukodit" voidaan paikantaa; ks. Janhunen 1996) kuin itse Siperiassa. Vasta ehkä vuoden 3000 eaa. tienoilla esi- tai varhaiskantauralin puhujat olisivat saapuneet indoeurooppalaisten naapureiksi, ja varhaisimpia lainoja olisi saatu sekä esi- tai varhaiskanta-arjasta että arkaaisesta (luoteis)indoeuroopasta. 


\section{Uusi kuva hahmottuu}

Tässä tarkastelussa olen esittänyt, että kantauralin puhuma-alue näyttää kielitieteellisin perustein sijoittuneen Volgan mutkan ja Uralvuoriston välille Kaman vesistöalueelle. Kantaurali näyttää myös hajonneen vasta pohjoisen pronssikauden alkaessa suunnilleen vuoden 2000 eaa. tienoilla. Aivan samaan tulokseen on äskettäin päätynyt eri lähtökohdista Petri Kallio (2006), jonka tulos saa näin vahvistuksen.

Arkeologisten kulttuurien yhdistäminen kieliin on osoittautunut vaikeaksi. Suomessa on kantauralin puhuma-alue usein sijoitettu melko länteen, Ylä-Volgalle, josta on eri aikoina säteillyt vaikutusta Suomeen ja Baltiaan (esim. Carpelan \& Parpola 2001: 78-83). Venäläisessä ja unkarilaisessa tutkimuksessa puolestaan kantauralin puhuma-alue on usein sijoitettu Siperiaan, josta itäiset kielihaarat on helpointa johtaa. On myös kritisoitu sitä, että Ylä-Volgan neoliittisista kulttuureista on mahdotonta johtaa esimerkiksi samojedia (Kosinskaya 2001: 283). Ratkaistakseen tämän ongelman Christian Carpelan onkin esittänyt, että samojedi olisi levinnyt itään vasta pronssikautisen Seiman-Turbinon ilmiön mukana (Carpelan 1999: 270). Petri Kallion mukaan samaan pronssikautiseen ilmiöön voitaisiin hyvin yhdistää myös läntisten uralilaisten kielten leviäminen (Kallio 2006: 16-17).

Onkin mielenkiintoista, että arkeologisen aineiston perusteella uralilaisen ekspansion koko laajuuden selittäminen neoliittisista kulttuureista lähtien on hankalaa ja että edellä esitetyin kielellisin perustein uralilainen ekspansio on alkanut vasta pronssikaudella. Arkeologien onkin nyt syytä kääntää katseensa neoliittisista kulttuureista pronssikautisiin. Samalla on kuitenkin muistettava, että kantaurali ei suinkaan levinnyt välittömästi koko nykyiselle alueelleen vaan etenkin kielikunnan laidoilla kielialueet ovat laajentuneet vielä huomattavasti ja monessa eri vaiheessa varhaisimman uralilaisen ekspansion jälkeen (ks. esimerkkejä J. Häkkinen 2006b: 61).

Toinen arkeologisen aineiston tulkintaan liittyvä ongelma on menneisyyden kielitilanteen tuntemattomuus. Suurin osa Euroopan muinaisesta kielellisestä diversiteetistä on kadonnut ekspansiivisten kielikuntien (indoeurooppalainen, uralilainen, turkkilainen) alle. Arkeologi saattaa kysyä minkä tahansa nykyuralilaisen alueen kohdalla, mitä kieltä alueella sitten olisi puhuttu kivikaudella ellei uralilaista? Vaikkemme osaakaan nimetä noita kadonneita kieliä, niiden olemassaolo on silti looginen välttämättömyys: jokainen ekspansiivinen kielikunta on peräisin yhdestä suppea-alaisesta kantakielestä, jota on puhuttu vain yhdellä kielikunnan nykyisten kielten kattamista kymmenistä puhuma-alueista, ellei kokonaan niiden ulkopuolella. Kaikilla muilla kielikunnan nykyään kattamilla alueilla on aiemmin puhuttu muita kieliä. Silti arkeologinen jatkuvuus on ilmeinen osapuilleen kaikkialla, joten laaja-alaisten kielikuntien kohdalla arkeologinen jatkuvuus ei vastaakaan kielellistä jatkuvuutta vaan kielellistä epäjatkuvuutta sitä todennäköisemmin, mitä laaja-alaisempi kielikunta on kyseessä. (J. Häkkinen 2006a.)

Tästä kaikesta seuraa, että uralilaisen kielen leviämistä ei voida enää yhdistää tyypilliseen kampakeramiikkaan, kuten Suomessa viime vuosikymmeninä ns. maltillisessa jatkuvuusteoriassa (ks. esim. symposiumkokoelmat Gallén 1984 ja Fogelberg 
1999) on totuttu tekemään: siinähän itämerensuomen ja saamen eriytymisen on nähty alkaneen jo kivikaudella indoeurooppalaisena pidetyn nuorakeraamisen kulttuurin levittyä Lounais-Suomeen noin 3200 eaa. alkaen. Jatkuvuusteorian perusteluja kohtaan on hiljattain alettu esittää kritiikkiä (Aikio \& Aikio 2001), ja tämän tarkastelun perusteella teoria ei voikaan pitää paikkaansa: kampakeramiikan leviämiskeskus YläVolgalla on ollut sekä liian läntinen että liian varhainen voidakseen liittyä uralilaiseen ekspansioon. Samaan johtopäätökseen johtavat myös eräät muut kielentutkijoiden viime vuosina julkaisemat tulokset, jotka tässä lyhyesti esiteltäköön:

Janne Saarikivi on selvittänyt saamelaisperäisen paikannimistön levinneisyyttä Pohjois-Venäjällä: nimistön alue näyttää ulottuvan Äänisen kaakkoispuolelle saakka (Saarikivi 2004b = 2006: 169-234). Tällainen levinneisyys viittaa siihen, että kantasaamelainen kehitys on alkanut jossain alueen eteläosissa, toisin sanoen Suomen kaakkoispuolella. Samaan näyttäisi viittaavan epänormaalin "parasaamelaisen" paikannimiaineksen esiintyminen Äänisen eteläpuolella (Aikio 2006b: 42): varhaisen kantasaamen murteutuminen näyttäisi siis alkaneen jo noilla tienoin kaukana Suomen kaakkoispuolella, vaikka nykypäivään on säilynyt vain yksi sen tytärmurre, myöhäiskantasaamen kautta nykyisiin saamelaiskieliin johtava linja.

Kantasuomen ekspansiokeskus puolestaan paikannetaan Suomenlahden eteläpuolelle (Saarikivi \& Grünthal 2005; Kallio 2007), ja sekä kantasaamelainen että kantasuomalainen kehitys näyttävät alkaneen paljon aiemmin oletettua myöhemmin. Jorma Koivulehto on osoittanut, että sellaisetkin kantagermaania myöhäisemmät lainasanat, joissa ilmenee vain länsi- ja pohjoisgermaanille ominainen äänteenmuutos $*_{\bar{e}}>*_{\bar{a}}$, on omaksuttu vielä varhaiskantasaamelaiseen ja varhaiskantasuomalaiseen kielimuotoon (Koivulehto 1999b, 2002). Kyseinen germaaninen murrekehitys ei voi olla kovinkaan paljon ajanlaskun alkua varhaisempi (Koivulehto 1999b: 271), ja myöhäisen ajoituksen vahvistaa saamen sana ruovdi 'rauta', joka niin ikään on vielä

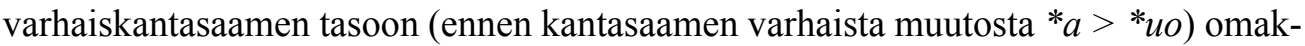
suttu kantagermaaninen laina (Aikio 2006b: 39) - ja luonnollisestikaan rautaa ei ole tunnettu ennen rautakautta, joka pohjoisessa Euroopassa alkoi noin 500 eaa.

Mainittujen murteellisten germaanisten lainojen aikaan varhaiskantasaame ja varhaiskantasuomi olivat kuitenkin jo alueellisesti, vaikkeivät juurikaan kielellisesti eriytyneet, mikä näkyy niin lainasanojen levikistä kuin niiden äännesubstituutioistakin: varhaiskantasaamessa myöhäisgermaaninen *h jäi ilman substituuttia (katoedustus), kun taas varhais- tai keskikantasuomessa germaaninen *h substituoitiin tähän aikaan *h:1la (ks. esimerkkejä Aikio 2006b: 10; Koivulehto 1999b).

Näyttää siis siltä, että länsiuralilaisen murteen (= suomalais-saamelais-mordvalainen kantakieli) länsipään hajoaminen on alkanut jo suunnilleen Suomenlahden pohjukan ympäristössä ja ehkä vasta rautakaudella, mutta joka tapauksessa aikaisintaan vuoden 1000 eaa. jälkeen. Näin kivikautisen Lounais-Suomen kulttuureilla ei voi olla mitään tekemistä itämerensuomen ja saamen eriytymisen kanssa. Tulevaisuudessa monitieteisessä tutkimuksessa onkin keskityttävä vastaamaan kokonaan uudelta pohjalta kysymyksiin: (1) Mitä kieltä tyypillisen kampakeramiikan piirissä sitten olisi puhuttu? (2) Mihin arkeologisiin kulttuureihin kantauralin leviäminen nyt voidaan 
yhdistää? (3) Mitkä tekijät selittävät uralilaisen ekspansion? Tässä yhteydessä näitä kysymyksiä voidaan sivuta ainoastaan pintapuolisesti.

Tyypillinen kampakeramiikka on osa sitä (sub)neoliittisten kulttuurien jatkumoa, jossa Ylä-Volgan alue on toistuvasti levittänyt vaikutustaan Suomen ja Baltian suuntaan (ks. esim. Carpelan 2000). Epäilemättä mukana on kulkeutunut myös kielellistä vaikutusta, mutta edellä esitetyn perusteella se ei ole vielä voinut olla uralilaista. Aikaisemmin tässä tarkastelussa esitin, että uralilaiselle fonotaksille vieraita piirteitä $\left(*_{m m}, *_{n n}, *_{s ̌ n}, *_{s ̌ m}\right)$ alkaa ilmestyä kieleen sanoissa, joilla on itämerensuomesta mordvaan ulottuva levikki (sikäli kuin marin ja permin sanat ovat nuorempia lainoja) ja jotka on todennäköisimmin lainattu pääosin vasta Volgan eteläpuolisella lehtimetsävyöhykkeellä. Lehtimetsävyöhykkeen paleoeurooppalaisen lainanantajakielen fonotaksi näkyy siis poikkeavan kantauralista erityisesti nasaalikonsonanttien vapaamman kombinoitumisen osalta. Kuitenkin joitain tällaisia sanoja tunnetaan jo suomalais-permiläisen levikin omaperäisistä sanoista: *kišñä- 'aivastaa', *śäśnä 'tikka' (Sammallahti 1988: 552-554), *tušma 'laiska; saamaton; vastusteleva' (Saarikivi 2007: 333).

Fonotaksiltaan samanlainen kieli näyttää olleen läsnä myös Baltiassa ja Suomessa, kuten havaitaan yhtäältä itämerensuomeen ja toisaalta saameen rajoittuvista sanoista, joita on pidetty substraattilainoina paleoeurooppalaisesta kielestä. Itämerensuomeen rajoittuvissa sanoissa tavataan geminaattanasaaleja, kuten esimerkiksi sanoissa konna 'rupikonna (Bufo bufo)' ja nummi, jotka Janne Saarikivi mainitsee itämerensuomen mahdollisten substraattilainojen joukossa (Saarikivi 2004a: 188; 2006). Ante Aikion mukaan myös saamen substraattisanastossa esiintyy sellaisia sanoja, jotka näyttävät palautuvan geminaattanasaaliseen asuun: saameP lidnu $<$ saame *linnō 'huuhkaja (Bubo bubo)' | saameP dápmot < saame *tāmmōkkē 'taimen (Salmo trutta)'. Toisin kuin monissa muissa saamen substraattilainoissa, näissä sanoissa ei ole epäetymologisia vokaalikombinaatioita, jotka pakottaisivat pitämään sanoja myöhäisinä, vasta Lapissa kantasaamen loppuvaiheessa omaksuttuina lainoina; ne onkin saatettu lainata jo varhaiskantasaameen jossain nykyistä saamelaisaluetta selvästi etelämpänä, esimerkiksi Etelä-Suomessa. (Aikio 2004: 13.)

Myös sibilantin ja nasaalin yhtymiä tavataan, mutta osalle tällaisista sanoista on esitetty indoeurooppalainen lainaoriginaali: suomalais-volgalainen *ši(k)šna 'hihna' olisi lainattu baltista (esim. Kalima 1936: 81, 191) ja saamelais-mordvalainen *reśma 'köysi' esiarjasta (Koivulehto 2001: 250). Aihepiirinsä puolesta nämä lienevät pikemminkin kulttuurisanoja kuin substraattilainoja.

Janne Saarikivi mainitsee fonotaktisesti epäuralilaisina vielä $*_{s}$ :ään päättyvät sanat ilves ja jänis (Saarikivi 2004a: 208; 2006). Mainittujen sanojen yhteyteen voidaan liittää vielä varis, jonka alkuperä on niin ikään tuntematon (vaikka samantapaisia mutta $s$ :ttömiä nimityksiä tavataan etäsukukielistä); sanan vartalo voisi olla äänteellisesti motivoitu linnun ääntelyä mukaillen, mutta sananloppuinen $s$ ei selity tältä pohjalta. Merkittävää on, että tämän ryhmän sanat taipuvat eri tavalla kuin $s$-loppuiset balttilaiset ja germaaniset lainasanat: ilves : ilveksen $\sim$ vi. ilves : ilvese, jänis : jäniksen $\sim$ vi. jänes $:$ jänese, varis $:$ variksen $\sim$ vi. vares $:$ varese $\mid$ kirves $:$ kirve $(h) e n \sim$ vi. kir- 
ves : kirve, vieras : viera(h)an $\sim$ vi. võoras : võora. Ilmeisesti ensimmäisen ryhmän sanoissa onkin ollut alkuaan jokin monimutkaisempi konsonanttiaines tai -yhtymä, joka on kantasuomessa säilynyt erillään sananloppuisen "tavallisen" $s: n$ edustuksesta. Nuoremmat lainat ovat jälleen sopeutuneet ensimmäiseen taivutustyyppiin, ilmeisesti paradigman koheesion vuoksi: $h$ tai katoedustus tuntuu liian erilaiselta sopiakseen $s: n$ vaihtelupariksi. Ja kaikkein nuorimmissa lainoissa $s$ ei lainkaan vaihtele.

Myös saamen vastineista saadaan jonkinlaista tukea monimutkaisen loppukonsonantin puolesta: suomen varis-sanan vastineeksi rekonstruoidaan kantasaameen *vuoreć (Lehtiranta 1989: 154). Sen sijaan ilves-sanan vastine rekonstruoidaan kantasaameen $s$-loppuisessa asussa *elpes (Lehtiranta 1989: 10), mutta tällä sanalla on saamessa hyvin suppea levikki. Paleoeurooppalaisessa substraattikielessä lienee ollut näissä sanoissa alkuaan sananloppuinen affrikaatta: saamen sekundaari affrikaatta $* \dot{c}\left(<\mathrm{U} * *^{\prime}\right)$ selittyy siitä lähtien, samoin kantasuomen *ks rinnakkaistapauksen avulla. Varhaisten iranilaisten lainasanojen aikaan uralilaisessa lainansaajakielessä oli vain yksi affrikaatta ${ }^{*}$, eikä dentaalista ${ }^{*}$ :tä sen paremmin kuin ${ }^{*} t s$-yhtymääkään ollut, joten iranilainen dentaaliaffrikaatta $* t s$ tai $* d z$ korvattiin $* k s$-yhtymällä (Koivulehto 1999a: 219-224). Samanlainen substituutio olisi voinut tapahtua, kun paleoeurooppalaisia sanoja lainattiin keskikantasuomeen liudentuneiden konsonanttien jo kadottua sen äännejärjestelmästä, ja sananloppuinen $* k s$-aines olisi sitten yksinkertaistunut *s:ksi ja säilynyt vain sanan sisällä taivutusmuodoissa.

Lisätodisteen sen puolesta, että Suomessa ja Baltiassa olisi ennen alueiden uralilaistumista puhuttu samaa kieltä, tarjoaa sanue suomi salo $\sim$ saameP suolu 'saari'

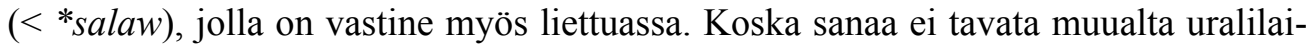
sista kielistä, on sanaa uralilaisella puolella pidetty balttilaisena lainasanana. Mutta tämäkään oletus ei vaikuta uskottavalta, koska balttilaiselta sanalta puuttuvat niin ikään indoeurooppalaiset vastineet. Lisäksi saameen on Lapissa omaksuttu substraattilainoina paikannimiä, joista voidaan eristää nimielementti sáll- 'suuri saari merellä' (Aikio 2004: 24). Nämä nimet voisivat olla samasta paleoeurooppalaisesta sanueesta myöhemmin saamelaiskieliin omaksuttuja. Kyse onkin todennäköisesti jostakin Suomen ja Baltian alueiden aikaisemmasta kielestä erikseen Suomenlahden molemmin puolin omaksutusta substraattilainasta.

Käsitellyt sanat sisältävät uralilaiselle fonotaksille vieraita piirteitä ja niillä on suppea levikki uralilaisessa kielikunnassa, joten niitä voidaan pitää lainasanoina. Lisäksi ne edustavat aluesidonnaista sanastoa (kasvit, eläimet, maastokohteet), joka on erityisen altista lainautumaan substraattitilanteessa (Aikio 2004; Saarikivi 2004a; 2006). Koska suurimmalle osalle sanoista ei ole esitetty indoeurooppalaista tai muutakaan lainaoriginaalia, on oletettava kielen edustaneen jotain sittemmin kadonnutta paleoeurooppalaista kielikuntaa.

Tässä esitetyn paleoeurooppalaisen kielellisen vaikutuksen leviäminen YläVolgalta Suomeen ja Baltiaan voitaisiin yhdistää kampakeraamisiin kulttuureihin. Kun epäuralilaisia äänneyhtymiä näyttää tulleen kieleen jossain määrin jo suomalaispermiläisessä vaiheessa (kantauralin läntis-keskinen murreryhmä), voidaan läntisen eli tyypillisen kampakeramiikan lisäksi kampakeramiikan keskisen ryhmän (jonka 
alue ulottuu idässä Volgan mutkaan; ks. kartta Huurre 2004: 25) piirissä olettaa puhutun samansukuisia tai ainakin fonotaksiltaan samanlaisia paleoeurooppalaisia kieliä. Näistä selvästi jo erilleen jäävän itäisen kampakeramiikan (Volgan mutkasta itään ja koilliseen) piirissä sen sijaan ei tällaista kieltä näyttäisi puhutun. Kielialueen ja mainittujen kulttuurien alueellinen yhteneväisyys on selvä (ainakin yhtä selvä kuin vallitseva käsitys itämerensuomalais-saamelaisen kielialueen ja tyypillisen kampakeramiikan yhteydestä), ja myöhäiskivikautinen kampakeramiikka sopisi ajallisestikin varhaispronssikautista uralilaista ekspansiota edeltäneen kielen kantajaksi.

Toiseen kysymykseen en tässä syvenny kovinkaan laajasti, vaan tyydyn pintapuoliseen sopivien arkeologisten kulttuurien katsaukseen käsillä olleiden lähteiden pohjalta. On muistettava, että jatkuvuusteoriakin oli syntyolosuhteiltaan arkeologisen vastineen etsimistä silloisille kielitieteen tuloksille. Kun kielitieteen tulokset muuttuvat, muuttuu myös niihin sopiva arkeologinen vastine. Epäilemättä arkeologisesta aineistosta voidaan löytää ajan, paikan ja leviämissuunnan osalta sopivia kulttuureja, joiden avulla esitetyt uudetkin kielitieteen tulokset saadaan liitettyä osaksi konkreettista esihistoriaa.

Kantauralin puhuma-alueen olisin tämän tarkastelun perusteella valmis sijoittamaan Kamajoelle ja vuoden 2000 eaa. tienoille, joten huomio on kiinnitettävä tuolla alueella kivi- ja pronssikauden taitteessa (kolmannella ja toisella vuosituhannella eaa.) vaikuttaneisiin kulttuureihin. On merkillepantavaa, että kampakeraamisten kulttuurien välillä oli aukko juuri Keski-Volgan-Kaman pohjoispuolella (ks. kartta Huurre 2004: 25) ja että siihen aikaan kun kampakeraamisella alueella oli suuria suhteellisen yhtenäisiä kulttuurialueita, oli Kaman alueella useita pieniä kulttuurialueita: NovoIlinsk, Garino-Bor ja Jurtik (ks. kartta Carpelan \& Parpola 2001: 85). Tämä viittaa siihen, että alue ei ollut myöskään kielellisesti yhtenäinen, mikä on sopusoinnussa sen kanssa, ettei kantauralin ekspansio ollut vielä tähän aikaan alkanut. Ilman tarkempia tutkimuksia ei kuitenkaan ole mahdollista sanoa, minkä Kaman alueen kulttuurin piirissä kantauralia olisi puhuttu.

Garino-Bor-kulttuurin ja läntisemmän Volosovon kulttuurin välillä on yhtäläisyyksiä asumuksissa ja keramiikkatyylissä, mutta vaikutuksen suunnasta vallitsee erimielisyys (Carpelan \& Parpola 2001: 88). Volgan mutkan länsipuolella tapahtui pian vuoden 2000 eaa. jälkeen yhtenäistymistä, kun alueen vanhempi Volosovon kulttuuri, nuorakeraamiset Fatjanovon ja Balanovon kulttuurit sekä arjalaisena pidetty Abaševon kulttuuri sulautuivat tekstiilikeraamiseksi kulttuurialueeksi. Kuitenkin Ylä-Volgalla Okan haaran molemmin puolin syntyi Tširkovon kulttuuri, jonka keramiikalla oli yhtäläisyyksiä sekä Kaman alueen että Obin ja Irtyšin välisen Krotovon kulttuurin keramiikan kanssa. (Carpelan \& Parpola 2001: 87-88.)

Kantauralin puhuma-alue voitaisiin yhdistää johonkin Kaman kulttuureista, ja uralilaisen ekspansion ensimmäisen vaiheen voitaisiin ehkä olettaa näkyvän kulttuuriketjussa Tširkovo-Kama-Krotovo; ketjun läntisin lenkki osuu juuri sinne, missä länsiuralilainen murre ( $>$ esi-itämerensuomi ja esimordva) on siirtynyt Volgan eteläpuolelle, ja itäisin lenkki voisi vastata itäuralilaisen murteen etenemistä kohti Obin ja Jenisein yläjuoksuja, joilta myöhemmin löydämme kantasamojedin. Osapuilleen 
sama päälevinneisyys on Seiman-Turbinon pronssikauppaverkostolla: suuria löytökeskuksia on Euroopassa Ylä-Volgalla, Kamalla ja Petšoralla, Siperiassa Irtyš- ja Omjoen haarassa sekä Ket- ja Tšulymjoen välisellä alueella (ks. kartat Carpelan \& Parpola 2001: 99, 102, 103, 107). Yksittäisiä esineitä on löydetty vieläkin laajemmalta alueelta Ruotsista aina Altaille ja Baikaljärvelle saakka.

Myös Petri Kallio ehdottaa Seiman-Turbinon ilmiön sopivan ajan, paikan ja suunnan osalta mahdolliseksi uralilaisen kielen levittäjäksi (Kallio 2006: 16-17). On kuitenkin esitetty epäilyjä siitä, olisiko tällainen löyhä vaihdantaverkosto riittävä levittämään kokonaan uuden kielen Suomeen ja Baltiaan saakka - kyseessähän ei edes ole varsinainen erillinen kulttuuri (Koivulehto 2006: 158). Tässä vaiheessa ei uralilaista kieltä kuitenkaan edes tarvitse johtaa Suomeen ja Baltiaan saakka, koska esikantasuomi ja esikantasaame näyttäisivät alkaneen kehittyä jo idempänä ja vasta paljon myöhemmin. Ensimmäinen uralilainen ekspansiovaihe on siis ollut suhteellisen suppea-alainen, ja kielikunnan nykyinen levinneisyys on suurimmalta osin vasta paljon myöhäisempien, viimeisten kahdentuhannen vuoden aikana tapahtuneiden ekspansioiden tulosta. Lisäksi juuri tällainen laaja-alainen vaihdantaverkosto olisi hyvinkin voinut johtaa kielenvaihtoon; tästä enemmän seuraavan kysymyksen kohdalla.

Lopuksi kolmas kysymys: mikä oli syynä kantauralin ekspansioon? Kielen ekspansio voi tapahtua monella eri tavalla: kahden erillisen kulttuurin (ja niiden mukana kielten) "taistelu" alueellisesta dominanssista ei ole ainoa mahdollisuus. J. P. Mallory on esittänyt esimerkkejä sekä siitä, kuinka kielellinen ekspansio ei lainkaan näy arkeologisessa aineistossa, että siitä, kuinka kieli leviää alueelle uuden sosiaalis-hierarkkisen rakenteen välityksellä. Ensimmäinen seikka osoittaa, ettei arkeologinen jatkuvuuskaan voi sulkea pois uuden kielen saapumisen mahdollisuutta, vaikka siihen usein vedotaankin. Jälkimmäinen seikka puolestaan mahdollistaa kielen leviämisen juuri Seiman-Turbinon ilmiön kaltaisten löyhien vaihdantaverkostojen avulla, mikäli niihin liittyy uudenlaisia sosiaalis-hierarkkisia valtarakenteita. Mallory itse ehdottaa, että uralilaisen ekspansion takana saattaisi olla arjalaisilta lainattu uusi rakenne (kauppapäälliköt), joka olisi mahdollistanut kielen leviämisen paleoeurooppalaisten väestöjen käyttöön. Uusi kieli olisi levinnyt ensin laajimman sosiaalisen tason eli vuotuisten suurten kokoontumisten kautta (eräänlaiseksi yleiskieleksi), ja lopuksi perhetasolle saakka. (Mallory 2001.)

Kun käsillä olevan tarkastelun perusteella sellaiset myöhäiset arjalaiset lainasanat kuin '100', '1000', 'ruhtinas' ja 'kulta' voidaan palauttaa jo kantauraliin, samoin kuin tuntematonta alkuperää olevat pronssin ja sen seosmetallin nimitykset, näyttää Malloryn ehdotus suhteellisen uskottavalta: lainasanat heijastavat arvokkailla metalleilla käytyä kauppaa, sen mukanaan tuomaa tarvetta entistä suurempien lukujen käytölle (vaihtotavaroiden arvon määrittämiseksi) sekä kauppaverkoston synnyttämää uudenlaista hierarkkista asemaa. Arvokkaita metalliesineitä kuljettavat kaupparuhtinaat seurueineen ovat hyvinkin saattaneet sujuvasti muodostaa laajoille alueille laajimman ja korkeimman hierarkkisen tason, jonka piiriin tai jota jäljittelemään alkuasukkaat ovat pyrkineet.

Koska Seiman-Turbinon esineiden päälevinneisyys ulottuu valtavalle alueelle, on ainoa yhteinen kieli ollut pronssikauppiaiden kieli. Tilanne on sama esimerkiksi 
saamelaisilla: kahden eri saamelaiskielen puhujat eivät yleensä ymmärrä toistensa kieltä kovinkaan hyvin, joten he käyttävät keskenään sitä kieltä, jota kumpikin on oppinut toisena tai kolmantena kielenään (norja, ruotsi, suomi tai venäjä). Kantaurali olisi hyvinkin voinut olla tällainen kauppakieli, koska Seiman-Turbinon ilmiö on siinä määrin pohjoinen ja keskittyy myöhemmälle uralilaiselle alueelle, että sen piirissä on tuskin puhuttu esimerkiksi arjalaista kieltä.

Lopuksi on vielä huomattava, että sikäli kuin luoteisindoeurooppalaisen kielimuodon leviäminen Itämerelle voidaan edelleen yhdistää nuorakeraamiseen kulttuuriin, niin uralilainen kieli näyttäisi ehtineen Itämerelle vasta yli tuhat vuotta indoeurooppalaista kieltä myöhemmin. Aiemminkin on tietysti oletettu, että nuorakeraamisten kulttuurien indoeurooppalaiset niin Ylä-Volgalla kuin Suomessa ja Virossakin olisivat sulautuneet uralilaisiin, koska alueilla kerran puhutaan uralilaisia kieliä, mutta nyt prosessi on tulkittava toisin päin: uralilainen kieli onkin levinnyt indoeurooppalaisen päälle. Läntisiin uralilaisiin kieliin mahdollisesti tullut luoteisindoeurooppalainen vaikutus ei olisikaan enää superstraattia vaan substraattia. Mitään konkreettisia muutoksia itse lainaperäisen aineiston käsittelyyn uusi tulkinta ei kuitenkaan aiheuttane.

\section{Lähteet}

Aikio, Ante 2002: New and old Samoyed etymologies. - Finnisch-Ugrische Forschungen 57: 9-57.

Aikio, Ante 2004: An essay on substrate studies and the origin of Saami. - Irma Hyvärinen, Petri Kallio \& Jarmo Korhonen (toim.), Etymologie, Entlehnungen und Entwicklungen. Festschrift für Jorma Koivulehto zum 70. Geburtstag. Mémoires de la Société Néophilologique de Helsinki 63. Helsinki: Uusfilologinen yhdistys. 5-34.

Aikio, Ante 2006a: New and old Samoyed etymologies (Part 2). - Finnisch-Ugrische Forschungen 59: 9-34.

Aikio, Ante 2006b: On Germanic-Saami contacts and Saami prehistory. - Suomalais-Ugrilaisen Seuran Aikakauskirja 91: 9-55. [http://www.sgr.fi/susa/91/aikio.pdf 9.4.2009.]

Aikio, Ante 2007: Etymological nativization of loanwords. A case study of Saami and Finnish. - Diane Nelson, Ida Toivonen \& Mikael Vinka (toim.), Saami Linguistics. Amsterdam - Philadelphia: John Benjamins Publishing Company. 17-53.

Aikio, Ante \& Aikio, Aslak 2001: Heimovaelluksista jatkuvuuteen-suomalaisen väestöhistorian tutkimuksen pirstoutuminen. - Muinaistutkija 4/2001: 2-21. [http://cc.oulu.fi/ anaikio/ Heimovaelluksista_jatkuvuuteen.pdf 9.4.2009.]

Alatalo, Jarmo (toim.) 2004: Sölkupisches Wörterbuch aus Aufzeichnungen von Kai Donner, U. T. Sirelius und Jarmo Alatalo. Lexica Societatis Fenno-Ugricae XXX. Helsinki: Suomalais-Ugrilainen Seura.

Anthony, David W. 2001: Persistent identity and Indo-European archaeology in the western steppes. - Christian Carpelan, Asko Parpola \& Petteri Koskikallio (toim.), Early Contacts between Uralic and Indo-European: Linguistic and Archaeological Considerations. Suomalais-Ugrilaisen Seuran Toimituksia 242. Helsinki: Suomalais-Ugrilainen Seura. 11-36.

Anthony, David W. \& Brown, Dorcas R. 2008: Samara Valley Project. -http://users.hartwick.edu/ anthonyd/diet.html 9.4.2009. 
Bartens, Raija 1999: Mordvalaiskielten rakenne ja kehitys. Suomalais-Ugrilaisen Seuran Toimituksia 232. Helsinki: Suomalais-Ugrilainen Seura.

Beekes, Robert S. P. 1995: Comparative Indo-European Linguistics. An Introduction. Amsterdam - Philadelphia: John Benjamins Publishing Company.

Carpelan, Christian 1999: Käännekohtia Suomen esihistoriassa aikavälillä 5100-1000 eKr. Paul Fogelberg (toim.), Pohjan poluilla. Suomalaisten juuret nykytutkimuksen mukaan. Bidrag till kännedom av Finlands natur och folk 153. Helsinki: Suomen Tiedeseura. 249-280.

Carpelan, Christian 2000: Essay on archaeology and languages in the western end of the Uralic zone. - Congressus Nonus Internationalis Fenno-Ugristarum 7.-13.8.2000. Pars I. Tartu. 7-38.

Carpelan, Christian \& Parpola, Asko 2001: Emergence, contacts and dispersal of Proto-IndoEuropean, Proto-Uralic and Proto-Aryan in archaeological perspective. - Christian Carpelan, Asko Parpola \& Petteri Koskikallio (toim.), Early Contacts between Uralic and Indo-European: Linguistic and Archaeological Considerations. Suomalais-Ugrilaisen Seuran Toimituksia 242. Helsinki: Suomalais-Ugrilainen Seura. 55-150.

Flegg, Graham 2002: Lukujen historia. Helsinki: Art House.

Fodor, István 1975: Suomalais-ugrilaisen arkeologian pääongelmia. - Péter Hajdú (toim.), Suomalais-ugrilaiset. Helsinki: Suomalaisen Kirjallisuuden Seura. 52-77.

Fogelberg, Paul (toim.) 1999: Pohjan poluilla. Suomalaisten juuret nykytutkimuksen mukaan. Bidrag till kännedom av Finlands natur och folk 153. Helsinki: Suomen Tiedeseura.

Gallén, Jarl (toim.) 1984: Suomen väestön esihistorialliset juuret. Bidrag till kännedom av Finlands natur och folk 131. Helsinki: Suomen Tiedeseura.

Hajdú, Péter 1975: Sukulaisuuden kielellistä taustaa. - Péter Hajdú (toim.), Suomalais-ugrilaiset. Helsinki: Suomalaisen Kirjallisuuden Seura. 11-51.

Honti, László 1998: Ugrilainen kantakieli - erheellinen vai reaalinen hypoteesi? - Riho Grünthal \& Johanna Laakso (toim.), Oekeeta asijoo. Commentationes Fenno-Ugricae in honorem Seppo Suhonen sexagenarii. Suomalais-Ugrilaisen Seuran Toimituksia 228. Helsinki: Suomalais-Ugrilainen Seura. 176-187.

Huntley, Brian \& Birks, John 1983: An atlas of past and present pollen maps for Europe: 0-13000 years ago. Cambridge: Cambridge University Press.

Huurre, Matti 2004: 9000 vuotta Suomen esihistoriaa. Kahdeksas painos. Helsinki: Otava.

Häkkinen, Jaakko 2006a: Uralilaisen kantakielen tutkiminen. - Tieteessä tapahtuu 1/2006: $52-58$.

Häkkinen, Jaakko 2006b: Tulkintoja ja ylitulkintoja kansojen ja kielten alkuperästä. - Tieteessä tapahtuu 6/2006: 61-70.

Häkkinen, Jaakko 2007: Kantauralin murteutuminen vokaalivastaavuuksien valossa. Pro gradu -työ. Helsingin yliopiston suomalais-ugrilainen laitos. [https://oa.doria.fi/handle/10024/7044 6.7.2007.]

Häkkinen, Kaisa 1983: Suomen kielen vanhimmasta sanastosta ja sen tutkimisesta. Suomalais-ugrilaisten kielten etymologisen tutkimuksen perusteita ja metodiikkaa. Turun yliopiston suomalaisen ja yleisen kielitieteen laitoksen julkaisuja 17. Turku: Turun yliopiston suomalaisen ja yleisen kielitieteen laitos.

Häkkinen, Kaisa 1996: Suomalaisten esihistoria kielitieteen valossa. Tietolipas 147. Helsinki: Suomalaisen Kirjallisuuden Seura.

Häkkinen, Kaisa 1999: Esisuomalainen pyyntikulttuuri ja maanviljely sanaston valossa. - Paul Fogelberg (toim.), Pohjan poluilla. Suomalaisten juuret nykytutkimuksen mukaan. Bidrag till kännedom av Finlands natur och folk 153. Helsinki: Suomen Tiedeseura. 159-173. 
Häkkinen, Kaisa 2001: Prehistoric Finno-Ugric culture in the light of historical lexicology. Christian Carpelan, Asko Parpola \& Petteri Koskikallio (toim.), Early Contacts between Uralic and Indo-European: Linguistic and Archaeological Considerations. SuomalaisUgrilaisen Seuran Toimituksia 242. Helsinki: Suomalais-Ugrilainen Seura. 169-186.

IEW = Pokorny, Julius 1959: Indogermanisches etymologisches Wörterbuch. Bern: Francke Verlag.

Janhunen, Juha 1977: Samojedischer Wortschatz. Gemeinsamojedische Etymologien. Castrenianumin toimitteita 17 . Helsinki.

Janhunen, Juha 1996: Manchuria. An Ethnic History. Suomalais-Ugrilaisen Seuran Toimituksia 222. Helsinki: Suomalais-Ugrilainen Seura.

Janhunen, Juha 1998: Samoyedic. - Daniel Abondolo (toim.), The Uralic Languages. London - New York: Routledge.

Janhunen, Juha 2000: Reconstructing Pre-Proto-Uralic typology spanning the millennia of linguistic evolution. - Congressus Nonus Internationalis Fenno-Ugristarum 7.-13.8.2000. Pars I. Tartu. 59-76.

Janhunen, Juha 2001: Indo-Uralic and Ural-Altaic: On the diachronic implications of areal typology. - Christian Carpelan, Asko Parpola \& Petteri Koskikallio (toim.), Early Contacts between Uralic and Indo-European: Linguistic and Archaeological Considerations. Suomalais-Ugrilaisen Seuran Toimituksia 242. Helsinki: Suomalais-Ugrilainen Seura. 207-220.

Janhunen, Juha 2005: När kom finnarna till Finland? - Sphinx. Vuosikirja 2004-2005. Helsinki: Suomen Tiedeseura. 77-91.

Janhunen, Juha 2007: Typological expansion in the Ural-Altaic belt. - Incontri Linguistici 30: $71-83$.

Janhunen, Juha 2008: Some Old World Experience of Linguistic Dating. - John D. Bengtson (toim.), In Hot Pursuit of Language in Prehistory. Essays in the four fields of anthropology in honor of Harold Crane Fleming. Amsterdam: John Benjamins Publishing Company. 223-239.

Joki, Aulis J. 1973: Uralier und Indogermanen. Suomalais-Ugrilaisen Seuran Toimituksia 151. Helsinki: Suomalais-Ugrilainen Seura.

Jordan, David K. 2008: Ancient Metallurgy. A Beginners Guide. - http://weber.ucsd.edu/ $\sim$ dkjordan/arch/metallurgy.html 13.5.2008.

Kalima, Jalo 1936: Itämerensuomalaisten kielten balttilaiset lainasanat. Helsinki: Suomalaisen Kirjallisuuden Seura.

Kallio, Petri 2002: Prehistoric Contacts between Indo-European and Uralic. - Karlene Jones-Bley, Martin E. Huld, Angela Della Volpe \& Miriam Robbins Dexter (toim.), Proceedings of the Thirteenth Annual UCLA Indo-European Conference (Los Angeles, November 9-10, 2001). Journal of Indo-European Monograph Series 44. Washington D.C.: Institute for the Study of Man, Incorporated. 29-44.

Kallio, Petri 2004: Tocharian loanwords in Samoyed? - Irma Hyvärinen, Petri Kallio \& Jarmo Korhonen (toim.), Etymologie, Entlehnungen und Entwicklungen. Festschrift für Jorma Koivulehto zum 70. Geburtstag. Mémoires de la Société Néophilologique de Helsinki 63. Helsinki: Uusfilologinen yhdistys. 129-137.

Kallio, Petri 2006: Suomen kantakielten absoluuttista kronologiaa. - Virittäjä 110: 2-25. [http://www.kotikielenseura.fi/virittaja/hakemistot/jutut/2006_2.pdf 31.3.2006.]

Kallio, Petri 2007: Kantasuomen konsonanttihistoriaa. - Jussi Ylikoski \& Ante Aikio (toim.), Sámit, sánit, sátnehámit. Riepmočála Pekka Sammallahtii miessemánu 21. beaivve 2007. Suomalais-Ugrilaisen Seuran Toimituksia 253. Helsinki: Suomalais-Ugrilainen Seura. 229-249. [http://www.sgr.fi/sust/sust253/sust253_kallio.pdf 9.4.2009.] 
Kannisto, Artturi 1927: Über die früheren wohngebiete der wogulen im lichte der ortnamenforschung. - Finnisch-Ugrische Forschungen 18: 57-89.

Koivulehto, Jorma 1991: Uralische Evidenz für die Laryngaltheorie. Sitzungsberichte der Österreichischen Akademie der Wissenschaften, Philosophisch-historische Klasse 566. Wien: Verlag der Akademie.

Koivulehto, Jorma 1999a: Varhaiset indoeurooppalaiskontaktit: aika ja paikka lainasanojen valossa. - Paul Fogelberg (toim.), Pohjan poluilla. Suomalaisten juuret nykytutkimuksen mukaan. Bidrag till kännedom av Finlands natur och folk 153. Helsinki: Suomen Tiedeseura. 207-236.

Koivulehto, Jorma 1999b: Verba mutuata. Quae vestigia antiquissimi cum Germanis aliisque Indo-Europaeis contactus in linguis Fennicis reliquerint. Suomalais-Ugrilaisen Seuran Toimituksia 237. Helsinki: Suomalais-Ugrilainen Seura.

Koivulehto, Jorma 2001: The Earliest Contacts between Indo-European and Uralic Speakers in the Light of Lexical Loans. - Christian Carpelan, Asko Parpola \& Petteri Koskikallio (toim.), Early Contacts between Uralic and Indo-European: Linguistic and Archaeological Considerations. Suomalais-Ugrilaisen Seuran Toimituksia 242. Helsinki: Suomalais-Ugrilainen Seura. 235-264.

Koivulehto, Jorma 2002: Contact with non-Germanic languages II: Relations to the East. - Oskar Bandle (toim.), The Nordic Languages. An International Handbook of the History of the North Germanic Languages I. Berlin - New York: Walter de Gruyter. 583-594.

Koivulehto, Jorma 2006: Arkeologia, kielihistoria ja jatkuvuusteoria. - Mervi Suhonen (toim.), Arkeologian lumoa synkkyyteen. Artikkeleita Christian Carpelanin juhlapäiväksi. Helsinki: Helsingin yliopiston kulttuurien tutkimuksen laitos. 153-165.

Korhonen, Mikko 1984: Suomalaisten suomalais-ugrilainen tausta historiallis-vertailevan kielitieteen valossa. - Jarl Gallén (toim.), Suomen väestön esihistorialliset juuret. Bidrag till kännedom av Finlands natur och folk 131. Helsinki: Suomen Tiedeseura. 55-71.

Kosinskaya, L. L. 2001: The Neolithic period of north-western Siberia: The question of southern connections. - Christian Carpelan, Asko Parpola \& Petteri Koskikallio (toim.), Early Contacts between Uralic and Indo-European: Linguistic and Archaeological Considerations. Suomalais-Ugrilaisen Seuran Toimituksia 242. Helsinki: Suomalais-Ugrilainen Seura. 265-288.

Kulonen, Ulla-Maija 1999: Kulttuurisanat ja esihistoria. - Paul Fogelberg (toim.), Pohjan poluilla. Suomalaisten juuret nykytutkimuksen mukaan. Bidrag till kännedom av Finlands natur och folk 153. Helsinki: Suomen Tiedeseura. 207-236.

Lehtiranta, Juhani 1989: Yhteissaamelainen sanasto. Suomalais-Ugrilaisen Seuran Toimituksia 200. Helsinki: Suomalais-Ugrilainen Seura.

Lehtisalo, Toivo 1956: Juraksamojedisches Wörterbuch. Lexica Societatis Fenno-Ugricae XIII. Helsinki: Suomalais-Ugrilainen Seura.

Mallory, J. P. 2001: Uralics and Indo-Europeans: Problems of time and space. - Christian Carpelan, Asko Parpola \& Petteri Koskikallio (toim.), Early Contacts between Uralic and Indo-European: Linguistic and Archaeological Considerations. Suomalais-Ugrilaisen Seuran Toimituksia 242. Helsinki: Suomalais-Ugrilainen Seura. 345-366.

Nikolaeva, Irina 2006: A historical dictionary of Yukaghir. Trends in linguistics. Documentation 25. Berlin - New York: Mouton de Gruyter. 
Parpola, Asko 1999: Varhaisten indoeurooppalaiskontaktien ajoitus ja paikannus kielellisen ja arkeologisen aineiston perusteella. - Paul Fogelberg (toim.), Pohjan poluilla. Suomalaisten juuret nykytutkimuksen mukaan. Bidrag till kännedom av Finlands natur och folk 153. Helsinki: Suomen Tiedeseura. 180-206.

Rybatzki, Volker 2003: Intra-Mongolic taxonomy. - Juha Janhunen (toim.), The Mongolic Languages. Routledge Language Family Series 5. London - New York: Routledge Curzon. 364-390.

Saarikivi, Janne 2004a: Is there Palaeo-European substratum interference in western branches of Uralic? - Suomalais-Ugrilaisen Seuran Aikakauskirja 90: 187-214.

Saarikivi, Janne 2004b: Über das saamische Substratnamengut in Nordrußland und Finnland. - Finnisch-Ugrische Forschungen 58: 162-234.

Saarikivi, Janne 2006: Substrata Uralica. Studies on Finno-Ugrian substrate in northern Russian dialects. Tartu: Tartu University Press. [http://ethesis.helsinki.fi/julkaisut/ hum/suoma/vk/saarikivi/substrat.pdf 20.12.2006.]

Saarikivi, Janne 2007: Uusia vanhoja sanoja. - Jussi Ylikoski \& Ante Aikio (toim.), Sámit, sánit, sátnehámit. Riepmočála Pekka Sammallahtii miessemánu 21. beaivve 2007. Suomalais-Ugrilaisen Seuran Toimituksia 253. Helsinki: Suomalais-Ugrilainen Seura. 325-347. [http://www.sgr.fi/sust/sust253/sust253_saarikivi.pdf 9.4.2009.]

Saarikivi, Janne \& Grünthal, Riho 2005: Itämerensuomalaisten kielten uralilainen tausta. - Johanna Vaattovaara, Toni Suutari, Hanna Lappalainen \& Riho Grünthal (toim.), Muuttuva muoto: Kirjoituksia Tapani Lehtisen 60-vuotispäivän kunniaksi. Kieli 16. Helsinki: Helsingin yliopiston suomen kielen laitos. 111-146.

Salminen, Tapani 1999: Euroopan kielet muinoin ja nykyisin. - Paul Fogelberg (toim.), Pohjan poluilla. Suomalaisten juuret nykytutkimuksen mukaan. Bidrag till kännedom av Finlands natur och folk 153. Helsinki: Suomen Tiedeseura. 13-26.

[http://www.helsinki.fi/ tasalmin/lammi.html 12.3.2007.]

Salminen, Tapani 2001: The rise of the Finno-Ugric language family. - Christian Carpelan, Asko Parpola \& Petteri Koskikallio (toim.), Early Contacts between Uralic and IndoEuropean: Linguistic and Archaeological Considerations. Suomalais-Ugrilaisen Seuran Toimituksia 242. Helsinki: Suomalais-Ugrilainen Seura. 385-396.

[http://www.helsinki.fi/ tasalmin/tvarminne.html 12.3.2007.]

Sammallahti, Pekka 1988: Historical phonology of the Uralic Languages with Special Reference to Samoyed, Ugric and Permic. - Denis Sinor (toim.), The Uralic languages: Description, History and Foreign Contacts. Leiden: Brill. 478-554.

SSA = Itkonen, Erkki \& Ulla-Maija Kulonen (toim.) 1992-2000: Suomen sanojen alkuperä. Etymologinen sanakirja. I-III. Suomalaisen Kirjallisuuden Seuran Toimituksia 556, Kotimaisten kielten tutkimuskeskuksen julkaisuja 62. Helsinki: Kotimaisten kielten tutkimuskeskus - Suomalaisen Kirjallisuuden Seura.

Steinitz, Wolfgang 1955: Geschichte des Wogulischen Vokalismus. Finnisch-Ugrische Studien II. Berlin: Akademie-Verlag.

Toivonen, Y. H. 1953: Suomalais-ugrilaisesta alkukodista. - Virittäjä 57: 5-35.

UEW = Rédei, Károly (toim.) 1988: Uralisches etymologisches Wörterbuch. Wiesbaden: Harrassowitz.

Vuorela, Irmeli 2002: Luonnon kerrostumat säilövät menneisyyttä. - Riho Grünthal (toim.), Ennen, muinoin. Miten menneisyyttämme tutkitaan. Tietolipas 180. Helsinki: Suomalaisen Kirjallisuuden Seura. 76-92. 


\section{Liite}

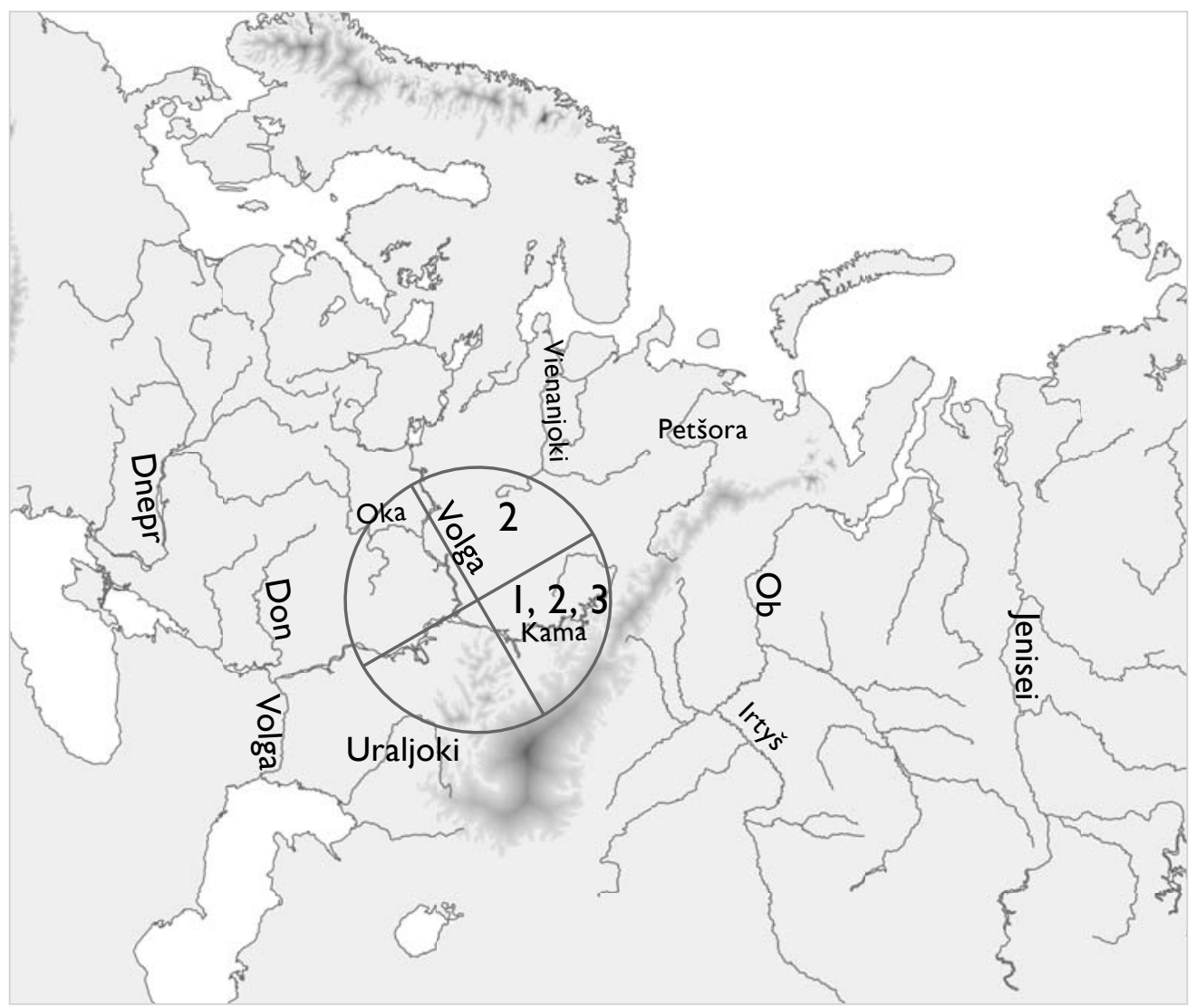

Kartta. Kantauralin puhuma-alueen paikantaminen.

Ympyrä = varhaisimman murteutumisen alue (luku 4.3)

$\mathrm{I}=$ kantauralilaisten puidennimien todistus (luku 4.4)

2 = jalojen lehtipuiden nimitysten todistus (luku 4.5)

3 = indoeurooppalaisten lainasanojen todistus (luku 4.6)

Jaakko Häkkinen <jaakko.hakkinen@helsinki.fi>

Suomalais-ugrilainen laitos

PL 25

00014 Helsingin yliopisto 